INTERNATIONAL MONETARY FUND

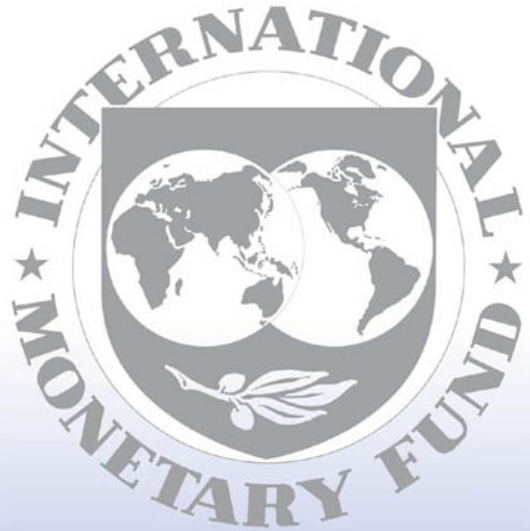

Staff

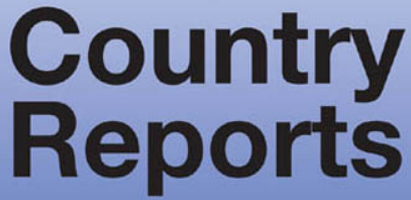




\section{Uruguay: Fourth Review Under the Stand-By Arrangement and Requests for Modification of the Arrangement and Waiver of Nonobservance and Applicability of Performance Criteria, and Extension of Repurchase Expectations in the Credit Tranches-Staff Report; Supplementary Information; Press Release on the Executive Board Discussion; Statement by the Executive Director for Uruguay; and Statement by the Authorities of Uruguay}

In the context of the fourth review under the Stand-By Arrangement and requests for modification of the arrangement and waiver of nonobservance and applicability of performance criteria, and extension of repurchase expectations in the credit tranches, the following documents have been released and are included in this package:

- the staff report for the fourth review under the Stand-By Arrangement and requests for modifications of the arrangement and waiver of nonobservance and applicability of performance criteria, and extension of repurchase expectations in the credit tranches, prepared by a staff team of the IMF, following discussions that ended on December 17, 2003, with the officials of Uruguay on economic developments and policies. Based on information available at the time of these discussions, the staff report was completed on February 9, 2004. The views expressed in the staff report are those of the staff team and do not necessarily reflect the views of the Executive Board of the IMF.

- Supplementary information of February 18, 2004 updating information on recent developments.

- a Press Release summarizing the views of the Executive Board as expressed during its February 20, 2004 discussion of the staff report that completed the review.

- a statement by the Executive Director for Uruguay.

- a statement by the authorities of Uruguay.

The documents listed below have been or will be separately released.

Letter of Intent sent to the IMF by the authorities of Uruguay*

Memorandum of Economic and Financial Policies by the authorities of Uruguay*

Technical Memorandum of Understanding*

*May also be included in Staff Report

The policy of publication of staff reports and other documents allows for the deletion of market-sensitive information.

To assist the IMF in evaluating the publication policy, reader comments are invited and may be sent by e-mail to publicationpolicy@imf.org.

Copies of this report are available to the public from

International Monetary Fund • Publication Services

$70019^{\text {th }}$ Street, N.W. • Washington, D.C. 20431

Telephone: (202) 623-7430 • Telefax: (202) 623-7201

E-mail: publications@imf.org Internet: http://www.imf.org

Price: $\$ 15.00$ a copy

International Monetary Fund

Washington, D.C.

(C)International Monetary Fund. Not for Redistribution 
This page intentionally left blank

CInternational Monetary Fund. Not for Redistribution 
INTERNATIONAL MONETARY FUND

\title{
URUGUAY
}

\begin{abstract}
Fourth Review Under the Stand-By Arrangement and Requests for Modification of the Arrangement and Waiver of Nonobservance and Applicability of Performance Criteria; and Extension of Repurchase Expectations in the Credit Tranches
\end{abstract}

\author{
Prepared by the Western Hemisphere Department \\ (In consultation with other Departments) \\ Approved by Markus Rodlauer and Liam P. Ebrill
}

February 9, 2004

- Stand-By Arrangement. The current arrangement, in the amount of SDR 2,128.3 million (694.4 percent of quota), covers the period through March 2005. Five purchases totaling SDR 1,476 million have been made so far, and a purchase of SDR 93.2 million becomes available upon completion of this review. On July 11, 2003, the Executive Board concluded the third review and the 2003 Article IV consultation. Directors welcomed the improvement in economic conditions and the debt exchange, but stressed the need for Uruguay to sustain strong fiscal policies, accelerate structural reforms-particularly in the banking area, and build a new growth momentum.

- Review discussions. Discussions were held in Montevideo during September 3-11, continued at Headquarters during December 1-3, and concluded in Montevideo during December 10-17. The mission met with Minister of Economy and Finance Alfie, Central Bank President de Brun, other senior officials, and representatives of the private sector. The staff team comprised Mr. Terrier (Head), Messrs. Braumann and Ma (all WHD), Ms. de Bolle and Ms. Kozack (both PDR), and Mr. Ley (FAD). MFD teams (Messrs. Lee and Seelig) overlapped with the missions. The missions were assisted by Mr. Bauer (Resident Representative). Mr. Le Fort (Executive Director) and Mr. Vogel (Senior Advisor, OED) attended meetings in Montevideo and at Headquarters.

- Program. In the accompanying Letter of Intent and Memorandum of Economic and Financial Policies, the authorities describe their economic program for 2004 and request waivers and a rephasing of remaining purchases under the arrangement. They have also requested that repurchase expectations arising during 2004 (SDR 227 million) be moved to an obligations basis.

- Economic and policy developments. Economic indicators have improved. With regard to the program's quantitative performance criteria, there was a small deviation from the target on the combined public sector primary balance. After some delays, the restructuring of public banks is being stepped up with a view to reducing the fragility of the banking system. Maintaining fiscal discipline in 2004 will be challenging as the approaching electoral campaign could weaken support for the government's economic program. The staff believes, however, that these and other program risks are manageable and, therefore, supports the authorities' request for waivers and for completing the review. 


\section{Contents}

Executive Summary

I. Background

II. Recent Developments and Performance under the Program..................................... $\underline{6}$

III. Policy Discussions ...................................................................................

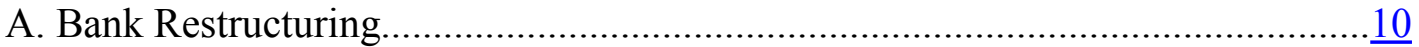

B. Fiscal and Monetary Policies................................................................... $\frac{12}{16}$

C. Trade Policies and Other Structural Reforms............................................... 16

IV. Program Financing, Monitoring, and Risks ................................................... 16

V. Data, Safeguards Assessments, and Other Issues ..........................................20

VI. Staff Appraisal ....................................................................................

Boxes

1. Institutional and Political Context .......................................................................

2. Growth Developments and Outlook .................................................................

3. Reprogrammed U.S. Dollar Deposits ..............................................................11

4. Public Debt Sustainability Analysis.................................................................. $\frac{14}{15}$

5. Monetary Policy Implementation in 2003 ........................................................ $\frac{15}{17}$

6. Short-Term Debt ................................................................................ 17

Figures

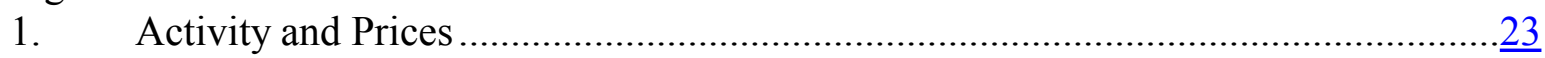

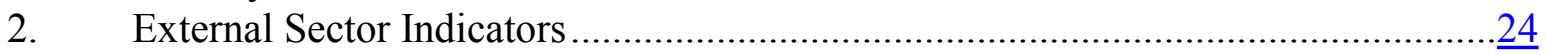

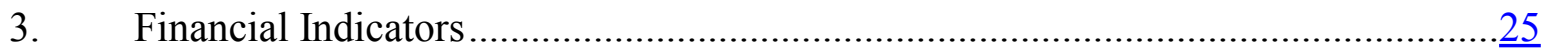

4. Fiscal and Monetary Indicators ..............................................................

Tables

1. Selected Economic and Financial Indicators .................................................... 27

2. Summary Balance of Payments................................................................. $\frac{28}{29}$

3. Performance Under the 2003 Economic Program ..............................................29

4. Combined Public Sector Operations ...................................................................

5. Cash Flow of the Nonfinancial Public Sector.......................................................

6. Summary Accounts of the Banking System.........................................................33

7. Medium-Term Outlook ..................................................................................... $\frac{34}{35}$

8. Proposed Schedule of Purchases ..................................................................... 
9. Projected Payments to the Fund and Indicators of Capacity

to Repay the Fund

10. Vulnerability Indicators

Appendixes

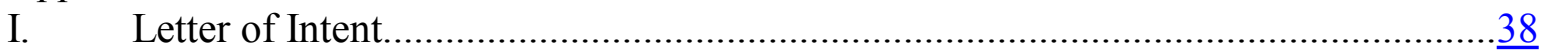

II. BROU: Financial Condition and Proposed Restructuring …………………….......52

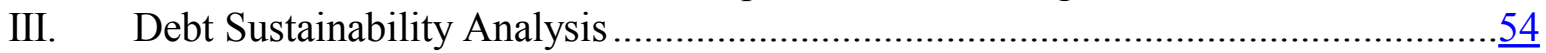

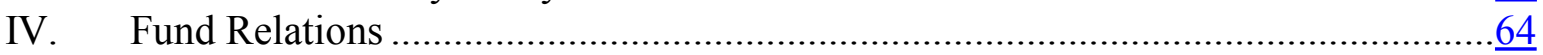

V. Relations with the World Bank Group..............................................................66

VI. Relations with the Inter-American Development Bank ………...............................67

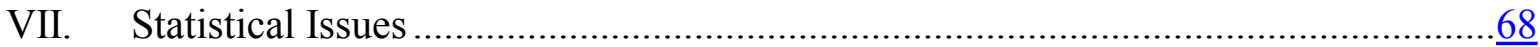

Attachments

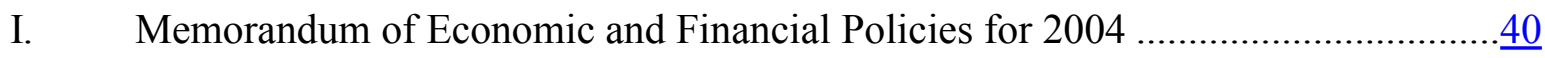

II. Technical Memorandum of Understanding ....................................................... 47 


\section{EXECUTIVE SUMMARY}

\section{Background}

Macroeconomic performance and financial market sentiment have continued to improve. Real GDP is now expected to have grown slightly during 2003, and inflation has declined faster than envisaged. Gross international reserves have strengthened further, and the banking system has continued to recover deposits. After the successful debt exchange, the authorities have been able to reestablish some access to international capital markets. Despite these encouraging trends, the situation remains fragile: bank restructuring is still at an early stage and bank deposits are on very short maturities; debt sustainability depends on continued sizeable primary fiscal surpluses; and a significant stock of short-term public debt has been accumulated.

The macroeconomic framework is broadly on track, but progress with structural reform has lagged. With regard to the quantitative performance criteria, there was a small deviation from the target on the combined public sector primary balance. The restructuring of the public banks and the disposal of assets of liquidated banks are taking longer than expected, and reforms in some other areas have largely lagged.

\section{Policy discussions and staff appraisal}

Uruguay's economy is expected to recover further in 2004. The macroeconomic framework for 2004 projects real GDP growth of 5 percent and a further decline in inflation, to 8 percent by year's end.

The authorities reaffirmed their commitment to the primary surplus targets for 2004 and beyond, which are essential to restore market confidence and bring the public finances to a sustainable path.

Swift implementation of the restructuring of BROU and the disposal of the remaining assets in the liquidation funds will be essential to ensure banking sector stability and foster a revival of lending.

Structural reforms will need to be accelerated, including to improve the investment climate, if the present recovery is to be followed by sustainable growth of incomes and employment.

Given the vulnerabilities, sustained implementation of the program will be critical during this election year.

Public sector debt service will remain high for a significant period of time, with possible need for continued Fund involvement beyond the current arrangement. 


\section{BACKGROUND}

1. The completion of this review (the fourth) has been delayed because the authorities needed more time to formulate and adopt a robust bank restructuring strategy. Building on the successful completion of the debt exchange last May, the authorities are proceeding with the needed restructuring of public banks while further strengthening the fiscal accounts.

\section{With the October 2004 elections approaching, the political environment is} becoming more challenging (Box 1). The campaign for the primaries has already started, risking a weakening of support in congress for the government's structural reform agenda. In December 2003, a referendum sponsored by the opposition led to the recall of a law that would have made it possible to eliminate the state monopoly in the fuel market and for the state oil company ANCAP to engage in partnerships with the private sector. Most political observers believe that this outcome reflected a protest vote against the government, due in part to the hardship caused by the country's long recession. However, the result also reconfirmed the reluctance of large parts of the electorate to allow increased private sector participation in activities run by the public sector.

\section{Box 1. Institutional and Political Context}

- ANCAP referendum. The December 7 referendum repealed the government-supported ANCAP law by 62 percent of the vote.

- Elections. The primaries for the October 2004 presidential and congressional elections are planned for late-June 2004. The new government is scheduled to take office in March 2005. Municipal elections will be held in May 2005.

- Support for the government. During 2001-02, President Batlle's cabinet included members of both the Colorado and the National parties. In November 2002, the National Party left the government while continuing to provide support for its economic program in congress. This support has weakened in recent months.

- Main political forces. Uruguay has a tradition of institutional and political stability. The Colorado Party and the National Party have alternated in power during most of the period since independence in 1830 . They are now being seriously challenged by the Encuentro Progresista-Frente Amplio (EP-FA) opposition, a coalition of left-leaning parties, which is currently ahead in the polls. In mid-December, the EP-FA endorsed a moderate platform for the forthcoming elections. 


\section{Recent Developments and Performance Under the Program}

\section{Economic recovery is now well}

under way. Real GDP grew by 3 percent (q/q, s.a.) on average during each of the first three quarters of 2003, driven mainly by net exports and, more recently, also by a recovery in consumption. Estimates for 2003 as a whole point to a slight increase in GDP, instead of a 1 percent decline projected at the time of the third review (Country Report No. 03/247). The unemployment rate fell from a peak of 19.8 percent in November 2002 to 15.4 percent in December 2003; initially, the drop in

\begin{tabular}{|c|c|c|c|c|c|c|}
\hline \multicolumn{7}{|c|}{$\begin{array}{l}\text { Uruguay: Selected Macroeconomic Indicators } \\
\text { (12-month percentage change, unless otherwise indicated) }\end{array}$} \\
\hline & \multirow[b]{2}{*}{2001} & \multirow[b]{2}{*}{2002} & \multicolumn{4}{|c|}{2003} \\
\hline & & & $\mathrm{Q1}$ & $\mathrm{Q} 2$ & $\mathrm{Q3}$ & $\begin{array}{l}\text { Q4 or } \\
\text { latest }\end{array}$ \\
\hline $\begin{array}{l}\text { Real GDP } \\
(\mathrm{q} / \mathrm{q}, \text { s.a. })\end{array}$ & -3.4 & -10.8 & $\begin{array}{r}-8.3 \\
2.0\end{array}$ & $\begin{array}{r}-4.8 \\
5.1\end{array}$ & $\begin{array}{l}7.1 \\
2.4\end{array}$ & $\begin{array}{l}\cdots \\
\ldots\end{array}$ \\
\hline $\begin{array}{l}\text { Unemployment } \\
\text { (eop, percent) }\end{array}$ & 14.9 & 18.6 & 18.6 & 17.5 & 16.0 & 15.4 \\
\hline CPI (end of period) & 3.6 & 25.9 & 28.5 & 24.6 & 11.6 & 10.2 \\
\hline Merchandise exports & -9.9 & -9.8 & -3.2 & 13.0 & 27.1 & 38.5 \\
\hline Merchandise imports & -12.1 & -35.7 & -9.2 & -12.3 & 38.7 & 44.6 \\
\hline REER (end of period) & -5.5 & -13.2 & -29.7 & -27.4 & -3.7 & -14.0 \\
\hline $\begin{array}{l}\text { CERES leading indicat } \\
\text { (q/q, s.a.) }\end{array}$ & & & -0.6 & 3.2 & 4.3 & 2.2 \\
\hline
\end{tabular}
unemployment was primarily due to a fall in labor force participation, but recent data point to an increase in employment. Nevertheless, reflecting the still large output gap, wage pressures in the private sector have remained modest, with 12-month increases at 5.1 percent by endNovember 2003.

4. Inflation has been falling faster than envisaged under the program. Consumer price increases averaged 0.6 percent a month during April-December (1 1/2 percent in the program). Consequently, year-end inflation was only 10.2 percent, well below program projections (20 percent). In real effective terms, Uruguay's currency depreciated by 14 percent during the first 11 months of 2003, on top of a 13-percent depreciation during 2002.

\section{Financial indicators}

have also improved. Gross international reserves have quadrupled since mid-March, to US\$2.1 billion at end-December (equivalent to $9 \frac{1}{4}$ months of imports), reflecting increased bank liquidity holdings at the central bank, purchases from the Fund (US $\$ 0.5$ billion), higher deposits of BROU following drawings from the Fund for the Stabilization of the Banking

\begin{tabular}{|c|c|c|c|c|c|c|c|}
\hline \multicolumn{8}{|c|}{$\begin{array}{l}\text { Uruguay: Changes in Dollar Deposits Held by the Banking System } \\
\text { (in US\$ million) }\end{array}$} \\
\hline & \multicolumn{3}{|c|}{2002} & \multicolumn{3}{|c|}{2003} & \multirow{2}{*}{$\begin{array}{r}2004 \\
\text { Jan-Feb }\end{array}$} \\
\hline & Jan-Jul & Aug-Dec & $\overline{\text { Year }}$ & Jan-Feb & Mar-Dec & Year & \\
\hline Total & $-5,846$ & -303 & $-6,149$ & -151 & 999 & 848 & 166 \\
\hline Public banks & $-1,317$ & -102 & $-1,418$ & -42 & 255 & 213 & 73 \\
\hline Private local banks & $-1,501$ & -350 & $-1,851$ & -13 & 84 & 70 & 30 \\
\hline Foreign banks & $-3,029$ & 149 & $-2,880$ & -96 & 661 & 565 & 62 \\
\hline Subsidiaries & $-1,573$ & -90 & $-1,664$ & -10 & 271 & 262 & 1 \\
\hline Branches & $-1,455$ & 239 & $-1,216$ & -86 & 390 & 303 & 61 \\
\hline Residents & $-2,338$ & -358 & $-2,696$ & -115 & 751 & 636 & 162 \\
\hline Nonresidents & $-3,509$ & 56 & $-3,453$ & -36 & 248 & 212 & 4 \\
\hline
\end{tabular}
System (US $\$ 0.3$ billion), and foreign-exchange purchases by the central bank. Net international reserves were still negative by US $\$ 0.7$ billion (program definition) at end-December, but significantly better than envisaged under the program (by US\$0.6 billion) (Table 3 ). Private sector foreign currency deposits in the banking system have continued to grow, and now 
significantly exceed their level at end-July 2002, on the eve of the bank holiday. Prudential bank indicators have also improved, as banks have increased their liquidity positions and provisions, and nonperforming loan (NPL) ratios have begun to recede. In June-July, the authorities released the first tranche of reprogrammed deposits at the public bank BROU (US\$570 million). So far, most deposits have remained with BROU, albeit predominantly in the form of sight and savings deposits. Finally, Uruguay's sovereign spread (EMBI) has dropped from almost 900 basis points at end-May 2003 to about 620 basis points in early-February 2004, broadly in line with regional trends.

6. The fiscal program is broadly on track. The end-September PC on the primary surplus of the combined public sector was not observed by a small margin. For the entire year 2003, preliminary data suggest that the primary balance shifted from zero in 2002 to a surplus of about 2.8 percent of GDP. The relatively small shortfall from the program target (a surplus of 3 percent of GDP) was due mainly to a lower-than-projected surplus of state-owned enterprises, offset in part by higher central government revenue. The government financed its deficit chiefly through multilateral disbursements and short-term domestic debt, taking advantage of lower interest rates after the May debt exchange. In October, access to international markets was reestablished, with the placement of a US\$200 million issue of three-year, peso-denominated, inflation-indexed bonds.

\section{Efforts to restructure the banking system made little progress during the second}

half of 2003. The end-August structural benchmark on the adoption of a restructuring plan for the public bank BROU was observed only in December. Progress with the World-Bank supported reform of the state-owned mortgage company BHU, which remains burdened by high operating costs and poor loan recovery, has also lagged. Also, progress in the disposal of the remaining assets of liquidated banks remained slow. The end-July structural PC on outsourcing the disposal of at least two asset groups was not observed. The authorities have since then revised their strategy in this area, with a view to outsourcing the entire stock of assets all at once. Developments at Nuevo Banco Comercial (NBC), created in March with the good assets of three liquidated banks, have been broadly in line with its business plan, although its wage bill has exceeded projections.

\section{Implementation of structural reforms in other areas has also been difficult.}

Although congress approved a legal framework for trust funds and the government successfully awarded the operation of the Montevideo airport to the private sector through competitive bids, the September structural benchmarks on legislative approval of the reforms of the special pension funds for the police and the military were not observed. Work on 
reforming the pension fund for bank employees (a December structural benchmark) has also been delayed, and there has been no progress on the reform of the tax system, submitted to congress in June. The authorities remain committed to these reforms, but explained that they needed more time to secure their approval. As a result of delays in structural reforms, multilateral loan disbursements fell short of program projections by US\$175 million during 2003, a shortfall that was offset by recourse to short-term borrowing.

\begin{tabular}{|c|c|c|c|}
\hline \multicolumn{4}{|c|}{$\begin{array}{l}\text { Uruguay: Program Loan Disbursements 1/ } \\
\text { (in millions of U.S. dollars) }\end{array}$} \\
\hline & \multicolumn{2}{|c|}{2003} & \multirow{2}{*}{$\begin{array}{l}2004 \\
\text { Proj }\end{array}$} \\
\hline & Proj. & $\overline{\text { Actual }}$ & \\
\hline IDB & 305 & 305 & 95 \\
\hline Financial Sector & 80 & 80 & 60 \\
\hline Reform of the State & 40 & 40 & 0 \\
\hline Health Sector & 25 & 25 & 0 \\
\hline Social Protection & 160 & 160 & 0 \\
\hline Multisectoral III & 0 & 0 & 35 \\
\hline W orld Bank & 250 & 75 & 100 \\
\hline SAL I & 100 & 0 & 100 \\
\hline SAL II & 150 & 75 & 0 \\
\hline Total & 555 & 380 & 195 \\
\hline
\end{tabular}

\section{Policy Discussions}

\section{Policy discussions mainly focused on bank restructuring, fiscal policy, and the} macroeconomic framework for 2004. The authorities and the staff agreed that, in the aftermath of the 2002 crisis, it was critical to address the remaining vulnerabilities in the banking system. A particular priority for reform is BROU, which accounts for about half of total bank deposits and has a large stock of nonperforming assets. In the fiscal area, the authorities emphasized the significant adjustment that took place during 2003 and reaffirmed their commitment to the primary surplus targets for 2004 and beyond.

\section{Discussions took place against the background of much improved macroeconomic} prospects. Based on the most recent indicators, including a strong export performance, the authorities and the staff agreed that, under conservative assumptions, real GDP would grow by 5 percent in 2004 (Box 2). Year-end inflation is projected at 8 percent, building on the declining trend in 2003. The external current account surplus is forecast at about $1 / 2$ percent of GDP, helped by favorable terms of trade and the recovery of demand in the region. The authorities agreed that further reforms would be needed to strengthen growth prospects for the medium term. They noted that significant actions had already been taken, but that building a new medium-term agenda for growth, in which the role of the private sector would be increased, required consensus which, realistically, could only be pursued after the forthcoming elections. 


\section{Box 2. Growth Developments and Outlook}

- GDP is recovering from the sharp contraction registered during 1999-2002 (18 percent cumulatively). The 2002 financial crisis caused a sharp drop in consumer spending, mostly due to a wealth effect as households suffered losses on their holdings of deposits, sovereign bonds, and real estate. The resolution of the banking crisis and the successful government debt exchange contributed to a recovery in consumer confidence in 2003.

- Higher net exports were at the heart of the economic recovery in 2003. A more competitive exchange rate and the reopening of overseas markets for meat boosted exports, while imports recovered more slowly. As is also common in V-shaped recoveries, a gradual rebound in private consumption contributed to the resumption of growth, especially in the second half of 2003, as evidenced by sharp increases in VAT and excise tax collections.

- However, signs of a recovery in investment remain weak, which raises questions about the sustainability of the recovery. Investment slumped after the 2002 financial crisis, as credit dried up and economic prospects deteriorated sharply. Construction has remained sluggish, and imports of capital goods, although picking up in recent months, are estimated to have fallen by close to 20 percent in U.S. dollar terms during 2003.

- The deep recession of 2002 caused significant shifts in income distribution. The income share of labor declined by an estimated 8 percentage points of GDP between 2001 and 2003, reflecting the fall in real wages and higher unemployment.

- The growth outlook for $\mathbf{2 0 0 4}$ is favorable. Real GDP growth is projected to reach at least 5 percent. Merely sustaining the level of activity reached in the last quarter of 2003 would imply average growth close to 4 percent in 2004. In addition, early indicators point to a promising tourism season, with visitor arrivals in late-2003 and early-2004 up by almost 40 percent. Significant growth is also expected in agriculture and industry.

- For the medium term, potential output is projected to grow modestly at $2 \frac{1}{2}-3$ percent per annum. Investment is likely to remain depressed for some time, particularly since the financial sector has shrunk. The last Article IV consultation emphasized the need to revive structural reforms aimed at increasing the role of the private sector and improving the institutional framework and business climate. 


\section{A. Bank Restructuring}

\section{As anticipated, BROU's restructuring is the centerpiece of efforts to strengthen} the banking system. ${ }^{1}$ In mid-December, BROU's Executive Board approved a strategic plan that aims at instilling sound banking practices (Appendix II). The bank intends to focus its business on the export sector, retail banking, and the development of peso-denominated financial products. Under the plan, BROU's balance sheet will be strengthened, operational costs lowered, and risk management and credit monitoring processes improved. The restructuring aims at ensuring that BROU complies with all prudential norms and is viable, with performance indicators that are in line with comparator banks. The main components of the reform are as follows:

- Nonperforming assets. The authorities are committed to removing a large part of the NPLs from BROU's balance sheet, with a view to cleaning up the balance sheet of the bank and strengthening the modalities for asset recovery. In December, all Category 5 loans above US $\$ 100,000$ (with a book value of US\$370 million) were transferred to a fiduciary trust owned by a subsidiary of BROU. ${ }^{2}$ All remaining Category 4 and 5 loans on BROU's books are to be transferred to the trust during the course of 2004, following the schedule defined in paragraph 10 of the MEFP. In exchange for the NPLs, the fiduciary trust will issue interest-bearing, governmentguaranteed notes. The notes will pay interest of $1 \frac{1}{2}$ percent, roughly equivalent to the cost of deposits. The amortization schedule is still being determined, and is expected to be closely linked to the asset recovery schedule. The staff welcomed the commitment by the authorities to maximize the recovery of NPLs, noting that the operations of the fiduciary trust should be managed transparently and according to international best practice, to minimize the amounts that might eventually be called under the government guarantee on the trust's notes. Accordingly, an outside manager is being retained to run the trust and implement asset recovery, with appropriate incentive targets.

- Operational performance and risk management. To reduce operating costs by some 15 percent over the next two years, the number of employees will be gradually reduced, including through early retirement schemes, and the bank's branch network rationalized. Interest rates on deposits will be better aligned with market levels to improve net interest margins. Credit risk administration will be bolstered with the

\footnotetext{
${ }^{1}$ The last staff report (Country Report No. 03/247) noted (paragraph 27) that BROU's restructuring would be a major focus of the present (fourth) review.
}

${ }^{2}$ Category 4 NPLs are loans overdue by 150-240 days; and Category 5 NPLs, by more than 240 days. 
implementation of improved risk management systems, including a credit scoring mechanism for small credits, improved credit risk assessment for medium-sized and large credits, and the development of consistent credit monitoring procedures.

- $\quad \boldsymbol{B H U}$ notes. At end-December 2003, arrears amounting to US\$170 million were cleared on the note issued by BHU to compensate BROU for taking over its reprogrammed time deposits (see Footnote 1). With the clearance of arrears, BHU's obligation to BROU has fallen to US\$610 million.

\section{The authorities and the staff concurred on the merits of maintaining a cautious} approach to managing the liquidity risks facing BROU. The bank will continue to build liquidity to ensure the timely repayment of reprogrammed deposits (Box 3). The authorities are committed to consulting closely with the staff on the treatment of these deposits. The authorities and staff concurred that the interest rate on these deposits would need to be reduced in line with market trends, but the authorities believed that they would be able to do so only in the context of advancing the release of the second tranche. Advancing the release of the remaining tranches should wait at least until BROU's restructuring is well under way. The staff had urged keeping the 100-percent reserve requirement on sight and savings deposits as a key safeguard for the bank while in crisis. However, as the restructuring progresses, reducing the reserve requirement is appropriate. BROU's restructuring plan assumes that the requirement will be reduced over time.

\section{Box 3. Reprogrammed U.S. Dollar Deposits}

Amounts. In August 2002, at the time of the banking crisis, all U.S. dollar time deposits with public banks, amounting to US\$2.2 billion (including US $\$ 0.8$ billion deposits of BHU that were transferred to BROU), were reprogrammed, with extended maturities of up to three years.

Repayment schedule. The schedule contemplated the repayment of 25 percent of principal (US $\$ 0.6$ billion) during the period August 2003-July 2004; 35 percent (US $\$ 0.8$ billion) during August 2004-July 2005; and the remaining 40 percent (US\$0.9 billion) during August 2005-July 2006. Reprogrammed deposits were to carry interest rates slightly above market interest rates; this rate was initially set at 6 percent, and has remained unchanged, even though market rates have since then declined significantly.

First tranche release. In June-July 2003, the authorities advanced the release of the first tranche of reprogrammed time deposits. To date, BROU has been able to retain most of these deposits, although mostly in the form of sight and savings deposits. 


\section{Progress is also being made in other areas of bank restructuring.}

- $\quad$ Liquidated banks. The launch of bids to outsource asset disposal for the three liquidated banks is a prior action for the review, and the final selection is a structural PC for endFebruary. With regard to the fourth liquidated bank, Banco de Crédito (BDC), in November the former minority shareholder completed the repayment of its outstanding liabilities by transferring government bonds with a face value of US\$93 million to the liquidation fund. The auction of a large portion of the remaining assets of BDC was held in late-January, advancing its liquidation.

- Nuevo Banco Comercial (NBC). The government is in the process of soliciting equity investments by the IFC and other institutional investors in this government-owned bank. Effective end-December 2003, NBC exercised its option to return to the liquidation funds all remaining nonperforming assets. The bank has been successful in attracting new deposits, and its operating results have been broadly in line with its business plan.

- Mortgage company BHU. BHU's restructuring is being accelerated during 2004. Due diligence on its portfolio was completed in December, and implementation of its restructuring plan has started, including downsizing, functional reorganization, and financial restructuring. The BHU's arrears to BROU have been cleared, and the payment terms of its remaining liabilities were brought in line with the authorities' expectations for BHU's earnings capacity.

14. The authorities continue to make progress in strengthening banking regulation. Prudential regulations are being aligned with international best practices, and the supervisory capacity of the BCU is being increased, with technical and financial support from the IDB and the Fund. The authorities are also taking steps to promote gradual dedollarization. Reserve requirements on peso deposits have been lowered relative to those on foreign currency deposits, and the $\mathrm{BCU}$ is working to adjust provisioning requirements to reflect more appropriately the risk of foreign currency loans to borrowers whose earnings are in local currency.

\section{B. Fiscal and Monetary Policies}

\section{Uruguay's primary fiscal balance improved significantly during 2003, although} the end-year target was likely missed by a small margin. Preliminary data indicate that the primary surplus in 2003 reached 2.8 percent of GDP, slightly less than the program target (3 percent of GDP) but still a major improvement from 2002. Both social security revenue and the operating surpluses of public enterprises fell short of expectations, but were partly offset by higher tax revenue. The overall deficit was smaller than program projections (by 0.3 percent of GDP), owing to lower interest obligations. 


\section{The authorities reaffirmed their strong commitment to achieving a primary} surplus of 3.2 percent of GDP in 2004. Achievement of this target will be helped by the cyclical recovery of tax and social security revenue and further adjustments in public tariffs. ${ }^{3}$ In early-January, the authorities raised utility tariffs by 6 percent on average, and they are committed to adjusting them further during the year, in line with cost developments. The government is also committed to keeping a tight grip on expenditure. To that effect, the wage increase granted in January was limited to 4 percent and, for 2004 as a whole, increases will not exceed 10 percent, broadly in line with projected inflation. The budget still provides some room for a recovery in public investment and for the one-time expenses associated with the elections, while protecting priority social expenditure.

\section{Prospects for tax reform remain elusive, but steps are being taken to strengthen} tax administration. A revised tax reform bill, aiming at eliminating several low-yielding taxes and broadening the VAT base, was submitted to congress in June 2003, in line with the program. The authorities reaffirmed their commitment to seek to build consensus for an early passage of the reform, but recognized that the process may take more time than expected, given the approaching elections. This reform is important to help rationalize the tax system and boost collections; in the meantime, the authorities reaffirmed their commitment to achieving the program objectives through appropriate expenditure restraint. The staff regretted the lack of progress on tax reform, but welcomed the approval in November of a law that provides additional resources to the Tax Administration Department (DGI) and enhances its ability to reform its internal structure. The planned modernization of the DGI, which is in line with FAD advice and supported with funds from the European Union, includes an overhaul of the DGI's processes and systems, significant retraining and improved incentives for its staff, and the creation of a Large Taxpayer Unit by end-September 2004 (a structural benchmark). At the same time, efforts are being intensified to fight tax evasion, including shifting responsibility for the supervision of tax-free zones from the Trade Department in the Ministry of Economy and Finance (MEF) to the DGI in the MEF.

\section{The authorities and the staff concurred on the crucial importance of maintaining} a sound fiscal position over the medium term. Achievement of a primary surplus of close to 4 percent of GDP by 2007 and maintaining it at this level in subsequent years would, assuming the realization of all contingent liabilities associated with bank restructuring, lead to a decline in the debt-to-GDP ratio to about 66 percent by 2012 (Box 4). Alternatively, if there were no additional costs of bank restructuring, the ratio would fall to 60 percent by 2012. The authorities noted that, if medium-term economic growth were to turn out higher

${ }^{3}$ During 2003, these tariffs were increased significantly on average by: 39 percent for petroleum products, 14 percent for telephone, $18 \frac{1}{2}$ percent for electricity, and 20 percent for water. 


\section{Box 4. Public Debt Sustainability Analysis}

Uruguay's high public debt stock continues to be a source of vulnerability, notwithstanding the successful debt restructuring of May 2003 and a significant drop in interest rate spreads. A key source of vulnerability lies in the banking sector, as the government faces large contingent liabilities reflecting potential calls over time on government guarantees in the restructuring of the public banks (up to US $\$ 1.3$ billion, or about 10 percent of GDP). These costs are related to the transfer of BROU's NPLs and the servicing of the BHU note, and include the interest cost of these guarantees. In a conservative approach, to ensure that all of these costs are captured, staff has constructed a scenario in which these contingent liabilities are fully realized. This is contrasted with a scenario in which these contingencies are excluded from the DSA.

If the government guarantees were to be called in full, the public debt-to-GDP ratio would reach 66 percent by 2012 . This compares with 60 percent in the scenario where no restructuring costs are realized. The debtto-GDP ratio declines in all cases, assuming potential GDP growth of $2 \frac{1}{2}$ percent, an average primary surplus of $3 \frac{1}{2}$ percent of GDP, and a modest appreciation of the real exchange rate. Financing gapsemerging in 2005 - are assumed to be closed through a combination of market and multilateral financing, possibly including the Fund.

Uruguay's public debt position is highly sensitive to macroeconomic shocks, as evidenced by the sensitivity tests presented in Appendix III (these shocks have been applied to the stock of debt including the costs of bank restructuring). However, it is important to recognize that Uruguay recently experienced such shocks and has adjusted its policies in response. The continued implementation of sound policies, along with deepening structural reforms, especially in the banking sector, will thus be crucial to minimize the likelihood of macroeconomic shocks and further improve prospects for debt sustainability.
Figure 1. Uruguay: Public Debt, 2001-12 (In percent of GDP)

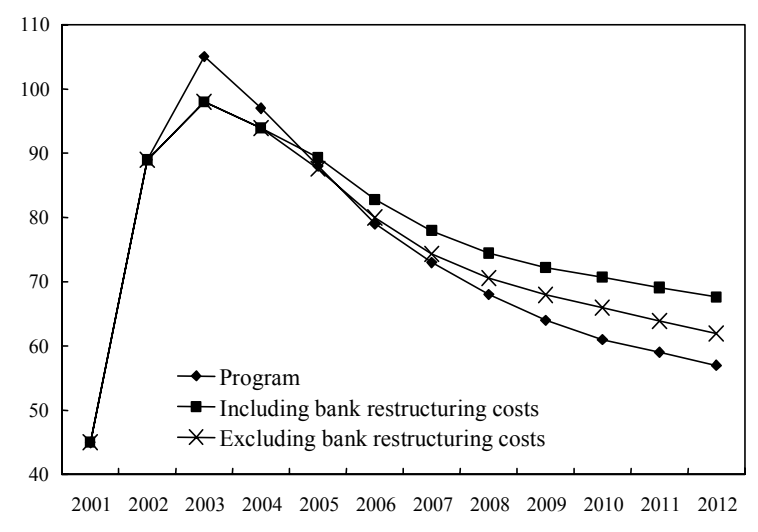

Source: Uruguayan authorities and Fund staff estimates.
Figure 2. Uruguay: Sensitivity Tests for Public Sector Debt, 2003-08 Includes Costs of Bank Restructuring (In percent of GDP)

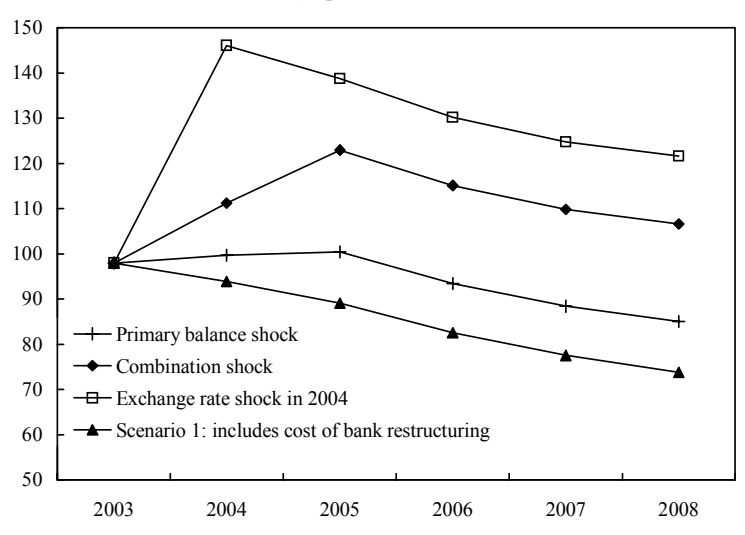

Source: Uruguayan authorities and Fund staff estimates. 
than currently anticipated, they would favor attaining even higher primary surpluses, targeting a zero overall balance for the combined public sector. The authorities also agreed to keep the adequacy of the fiscal target under continuous review, to ensure that it is sufficient to achieve debt sustainability, even with possible additional costs arising from contingent fiscal liabilities in connection with the restructuring of the public banks.

\section{The central bank will continue to target base money under the floating exchange}

rate regime. Staff commended the authorities for the sound conduct of monetary policy under difficult circumstances. Consistent with the goal of containing inflation, interest rates rose significantly in the first part of 2003, before gradually declining in the second half of the year. The authorities noted that forecasting money demand has been challenging, given the short period during which the floating exchange rate regime has been in place (Box 5). The authorities have announced a monetary program for 2004 that targets an expansion of base money of about 15 percent, consistent with a moderation in the remonetization process and a modest buildup in NIR (US\$100 million). Over the medium term, the authorities intend to move to inflation targeting; in January, a regular survey of inflation expectations was initiated.

\section{Box 5. Monetary Policy Implementation in 2003}

- In June 2002, Uruguay adopted a floating exchange rate policy and, in September 2002, began targeting base money.

- During 2003, base money developments were broadly in line with program projections. However, the growth in bank reserves was higher than initially expected, and currency in circulation lower. The growth of broader monetary aggregates was also lower than programmed.

- Furthermore, money demand turned out to be stronger than anticipated and, consequently, inflation ran well below expectations. An important component in the formation of inflation expectations in Uruguay is exchange rate developments, and the broad stability of the peso against the U.S. dollar during 2003 helped keep inflation at low levels.

- While the experience with base-money targeting in 2003 suggests that monetary policy could move toward inflation targeting (IT), the foundations for successful adoption an IT regime do not yet seem to be in place: (i) Uruguay is still in the process of fully restoring a strong fiscal position, macroeconomic stability, and the full functioning of its financial system; (ii) given the shocks that the economy and financial system have experienced, the monetary transmission mechanism is still in flux or not well established; (iii) the required institutional framework still needs to be established, including closer coordination between the foreign exchange and open market operations desks and sufficient availability of instruments; and (iv) central bank operational independence would need to be further strengthened. 


\section{Trade Policies and Other Structural Reforms}

20. Uruguay is deepening its integration into the global economy. A comprehensive bilateral free trade agreement with Mexico was signed in November which, once ratified by both congresses, will free about 93 percent of imports from tariffs and provide increased quotas and tariff discounts for a number of sensitive products such as beef, dairy products, and textiles. Uruguay is expected to further benefit from the recent free trade agreement between Mercosur and the Andean countries, although the precise calendar of tariff reductions still remains to be negotiated. The authorities are committed to the multilateral framework of trade liberalization and strongly support the early resumption of the Doha round. In early-2004, they also began to unilaterally phase out specific duties on textiles, foodstuffs, and chemical products.

\section{Steps are being taken to foster an environment conducive to private sector-led} investment and growth. The authorities noted that the protection of property rights in the resolution of the economic and financial crisis had helped improve investor sentiment toward Uruguay. They were encouraged by strong regional direct investment in the Uruguayan agricultural sector. Their efforts focus on promoting Uruguay's transformation into a regional distribution and logistics hub through: (i) a number of private concessions and public investments in the area of transport infrastructure (ports, airports, and railways); (ii) the recent approval by Mercosur of more generous rules of origin for goods in transit; and (iii) the extension until 2010 of Uruguay's regime for temporary admissions. Investment projects which were delayed because of the economic crisis will qualify for fiscal incentives for an additional two-year period. Finally, the authorities have initiated formal negotiations on a bilateral investment treaty with the United States.

22. The authorities reiterated their commitment to structural reforms in other areas. The staff expressed concern about delays in a number of areas, and reiterated the urgency of advancing structural reform to underpin a rebound in employment and medium-term growth. The authorities shared this concern, but noted that building the necessary political support had been time-consuming and would become more difficult as the elections approach.

Nevertheless, they would continue working to secure congressional approval of the reforms of the pension funds for the police and the military by end-June 2004 (structural benchmarks). They are also committed to seeking progress in reforms supported by program loans from the World Bank and the IDB.

\section{Program Financing, Monitoring, ANd Risks}

\section{Financing}

23. The program remains fully financed in 2004. Total disbursements from multilateral development banks are projected at US\$270 million in 2004, broadly in line with amortization. The government also plans to draw on a financing cushion of about US\$200 million accumulated at end-2003. Assuming close adherence to the fiscal program, 
residual market financing (after rolling over short-term debt) would be kept at US\$200-300 million, which the government is confident can be largely secured through issuance abroad of medium-term bonds. The stock of short-term debt would remain broadly unchanged during 2004 (Box 6). If market conditions permit, the authorities plan to issue more long-term debt in order to reduce the stock of short-term debt.

\section{Box 6. Government Short-Term Debt}

- The stock of short-term Treasury bills rose sharply in 2003, from US\$190 million to US\$810 million (7.2 percent of GDP). The increase mainly reflected Uruguay's difficulties in placing longer-term paper in the domestic and international markets in the aftermath of the 2002 crisis. After rising during the first three quarters of the year to close to US\$850 million, the stock of treasury bills declined slightly during the fourth quarter.

- $\quad$ Despite the high volume of issuance, maturities of Treasury bills lengthened and interest rates declined during the course of the year. Treasury bill maturities now reach up to 9 months, compared with 1-2 months in early-2003. Consequently, the average residual maturity of the stock of Treasury bills has risen to about three (four) months for peso (dollar) denominated bills. Interest rates have also declined significantly, to about 12 percent ( 3 percent) on 6-month bills in pesos (dollars). The currency denomination of the bills remains about evenly split between pesos and U.S. dollars.

- The program for 2004 assumes virtually no increase in the stock of short-term debt. The projected fiscal deficit and the maturing long-term debt are expected to be broadly covered by official financing and moderate access to long-term market financing.

\section{Access and monitoring}

24. Because of delays in completing the fourth review, a rephasing of access is proposed, with original access maintained for this review. Since the fourth review was originally scheduled for October, the authorities have requested a modification of access under the program, as set out in Table 8 . The proposed rephasing reflects the weight given to safeguarding Fund resources in light of policy slippages. In addition, it is proposed that the repurchase expectations arising during 2004 (SDR 227 million) be moved to an obligations 
basis. ${ }^{4}$ Repurchases could cause undue hardship at a time when the authorities are taking firm action to further strengthen the balance of payments and bolster confidence.

\section{While the broad monitoring framework under the program remains unchanged,} waivers and modifications are being requested. In the attached Letter of Intent, the authorities describe their policies for 2004 and request waivers of: (i) nonobservance of the end-December quantitative PC on the primary surplus of the combined public sector; (ii) nonobservance of the end-July structural PC on outsourcing the disposal of at least two asset groups from the liquidation funds; and (iii) applicability of the end-December quantitative PCs on the nonfinancial public sector gross debt and on general government noninterest expenditure. As noted, some of the structural benchmarks were observed with delays and others are still outstanding. The following remedial steps have been established as prior actions for completion of the fourth review: (i) a call for bids to outsource the management of the remaining assets in the three liquidation funds; (ii) selection of the general manager of the fiduciary trust handling the NPLs from BROU; and (iii) issuance of an unconditioned government guarantee on the performance of the notes to be issued by the fiduciary trust in exchange for loans transferred from BROU. The entering into a contract by the fiduciary trust with providers of specialized asset recovery services and the transfer of all Category 4 loans above US $\$ 100,000$ that have become Category 5 from BROU to the fiduciary trust will be structural PCs for end-March 2004, and all new and remaining Category 4 and 5 nonperforming loans will be transferred by end-2004 (Appendix I, Attachment I, Tables 1 and 2). A continuous structural PC has also been specified, providing for timely service of BHU's government-guaranteed obligation to BROU. Finally, approval by congress of the reforms of the special pension funds has been rescheduled as structural benchmarks for end-June (police and military) and end-December (bank employees).

\section{Total debt service obligations to the Fund would peak at close to 7 percent of} GDP in 2006 (Table 9). The high level of debt service may require Fund involvement beyond the present arrangement. In turn, it is critical to provide for close monitoring of Uruguay's performance under the program and prompt corrective action in case of shocks or policy slippages. Quarterly reviews will therefore continue under the program.

${ }^{4}$ The proposed extensions would cover the repurchase expectations of SDR 18.8 million arising on June 25, September 27, and December 27; SDR 15.3 million arising on July 2 and October 1; SDR 32.2 million arising on September 27 and December 27; and SDR 75.4 million arising on November 8. Extension of these repurchase expectations is consistent with the policies established by the Board regarding such extensions. 


\section{Program risks}

27. The overall balance of risks has somewhat improved from the third review, but substantial short- and medium-term vulnerabilities remain, leaving no room for complacency. The successful debt exchange in May has provided breathing space, which should be used to adopt measures to ensure fiscal sustainability and fully restore the banking system's viability.

- Attaining the primary surplus objective of the program will be challenging. As the 2004 presidential and congressional elections approach, pressures on the government to loosen the fiscal stance may rise. Failure to comply with the programmed surplus would create additional financing needs and raise doubts about the feasibility of the primary surpluses that will be required over the medium term to ensure debt sustainability. In this context, if additional fiscal costs related to the restructuring of BROU were realized, Uruguay's prospects for debt sustainability would worsen.

- $\quad$ The envisaged restructuring of the public banks may be strongly resisted by vested interests. In particular, it is critical that the fiduciary trust to which BROU's NPLs are being transferred be independently managed, to ensure effective recovery. While this would represent a major break from past practices, failure to proceed with the restructuring would risk creating significant additional liabilities for the government, further increasing the debt burden. BROU's progress in achieving financial viability will be closely monitored under the program, and will constitute a key element for completion of future reviews.

- The need to roll over significant amounts of short-term debt during 2004 makes Uruguay vulnerable to reversals in market sentiment. It will be essential to avoid slippage in program implementation and to maintain consistent communication with the markets in the run up to the elections, in order to sustain investor confidence. Favorable market conditions should be used - as intended by the authorities - to increase the maturity structure of the debt.

- Deposits are flowing back into the banking system, but mostly in the form of sight and savings deposits.

- Delays in disbursements from multilateral development banks could weaken the financing outlook and require higher recourse to market financing. It will therefore be essential to implement structural reforms in a timely and consistent fashion.

28. A number of buffers help mitigate — but do not fully eliminate - these vulnerabilities. The flexible exchange rate provides some support against external shocks, although the balance sheets of the government, private firms, and households remain 
significantly exposed to currency depreciation. Gross international reserves have been substantially rebuilt, but still do not provide much room for lender-of-last resort assistance. The banking system is cushioned by a high level of liquidity and improved credit quality, but both bank profitability and credit flows to the economy have yet to be restored.

\section{DAta, SAfeguards Assessment, AND Other IsSueS}

\section{Uruguay's statistical database remains generally adequate for the assessment} and monitoring of macroeconomic policies. The authorities have begun submitting data toward subscription to the SDDS, starting in October 2003 with dissemination on the BCU website of the data template for international reserves and foreign currency liquidity (an endSeptember structural benchmark). They are planning to formalize Uruguay's subscription to the SDDS in early-2004. Monthly bank balance sheet data are being published with a lag of no more than two months (a continuous structural benchmark). While the timeliness of data provision by BROU and NBC has improved, the state mortgage company BHU continues to provide balance sheet data with a long delay. The staff has also expressed concern about recurrent delays in reporting below-the-line fiscal data. The authorities are committed to improving the timeliness of reporting and to developing a more user-friendly presentation of above-the-line fiscal information for the general public.

\section{In line with the recommendations of the 2002 Safeguards Assessment mission, an} external audit of the FSBS was conducted in 2003 (an end-September structural benchmark). A supplemental audit, focusing on the use of FSBS resources by recipient banks, was initiated in early-2004. In addition, the BCU has retained an internationally reputable auditing firm to perform an external audit of its 2003 accounts. The authorities reaffirmed their commitment to combating money laundering and the financing of terrorism, noting the recent ratification by congress (in October 2003) of the UN International Convention for the Suppression of the Financing of Terrorism.

\section{Staff Appraisal}

31. After four years of recession, Uruguay's economy has started to recover. The adoption of prudent macroeconomic policies, skillful resolution of the 2002 banking crisis, and the successful debt exchange in early-2003 have been key to the economy's turnaround. The pace of the recovery gathered momentum during 2003, and the rate of growth is expected to further pick up in 2004, with inflation continuing on a downward trend. This performance has been supported by a more favorable external environment, including higher demand and prices for Uruguayan exports and improved financing conditions for emerging market economies. It will be important to develop a medium-term agenda for sustained growth, which should include an increased role for the private sector. 
32. However, the recovery remains fragile, and its consolidation will require continued sound policy implementation, particularly in the fiscal area and bank restructuring. The authorities' continued strong commitment toward achieving the primary surpluses targeted under the program for 2004 and beyond is welcome. While these targets are demanding, achieving them will be necessary to bolster market confidence and ensure sustainable debt dynamics.

33. The staff welcomes the steps taken to modernize tax administration, but regrets the lack of progress with tax reform. Improving the efficiency of both tax policy and tax administration is important to underpin fiscal management and provide a level playing field for private sector activity. The staff therefore encourages the government to continue its efforts to forge a consensus on tax reform.

\section{Monetary policy implementation has been prudent, and the staff supports} maintenance of the flexible exchange rate regime. The programmed expansion in the monetary base for 2004 is consistent with a further decline in inflation, while allowing some further remonetization of the economy. The staff welcomes the initiation of regular surveys of inflation expectations, and encourages the authorities' intention to move toward inflation targeting in the medium term.

\section{Restructuring of the public banks and swift disposal of the remaining assets in} the liquidation funds are crucial for banking system stability and the revival of credit flows. Timely implementation of the planned reforms at BROU is critical to ensure its viability and will contribute to improving creditor discipline and reducing moral hazard. BROU's remaining NPLs should be quickly transferred to the fiduciary trust, and required actions should be taken to achieve the targeted cost savings and to strengthen risk management. In addition, given the structure of the fiduciary trust, which will be owned by BROU, it will be critical to ensure that it is managed independently and in line with international best practice, so as to maximize recovery from NPLs and avoid additional costs to the government.

36. BROU's liquidity should continue to be conservatively managed. The reform of BROU should proceed with all deliberate speed. Until the restructuring of the bank is well under way, the staff recommends maintaining the original schedule for the unfreezing of reprogrammed deposits. As BROU's restructuring progresses, a reduction of the 100-percent reserve requirement on sight and savings deposits to 90 percent during 2004 is appropriate.

37. The staff is concerned about the delays with several other important structural reforms. Moving from the present recovery stage toward sustained growth will require acceleration of reforms, including further steps to boost the investment climate. The staff therefore urges all stakeholders to remain engaged in building an environment that is conducive to private-sector investment, as a basis for sustained growth. Approval of a 
number of structural reforms that are presently in congress and supported by the World Bank and the IDB would be an important step into the right direction.

38. Progress has been made in strengthening data reporting, but further improvement is needed. The staff welcomes the recent publication of the foreign reserve template and expects Uruguay soon to be able to fully subscribe to the SDDS. The availability and presentation of banking data have also improved markedly. The staff urges the authorities to take the necessary steps to improve the timeliness and presentation of fiscal data.

39. The program remains fully financed. Residual market financing needs should be manageable provided that the primary surplus target is achieved and structural reforms are implemented on schedule to unlock program lending from the World Bank and the IDB. Maintaining sound policy implementation and good communication with the markets during this election year will remain critical, particularly in view of the need to roll over a substantial amount of short-term public debt.

40. Despite the progress achieved to date, program risks remain sizeable.

Vulnerabilities stem mainly from the still-large public debt and its increased short-term component; the short maturity of bank deposits; sizeable contingent liabilities in the public banks; remaining balance sheet vulnerabilities; and the danger of policy reversal in an election year. The debt burden, while declining, will remain high for a significant period of time and the need for Fund involvement beyond the current arrangement is likely. Close program monitoring remains essential in view of these risks.

41. Notwithstanding these vulnerabilities, the staff recommends completion of the fourth review, approval of the authorities' request for waivers, and extension of repurchase expectations arising during 2004. Policy implementation in the banking area is broadly back on track, and the authorities have demonstrated and reaffirmed their strong commitment to the program objectives. 
Figure 1. Uruguay: Activity and Prices
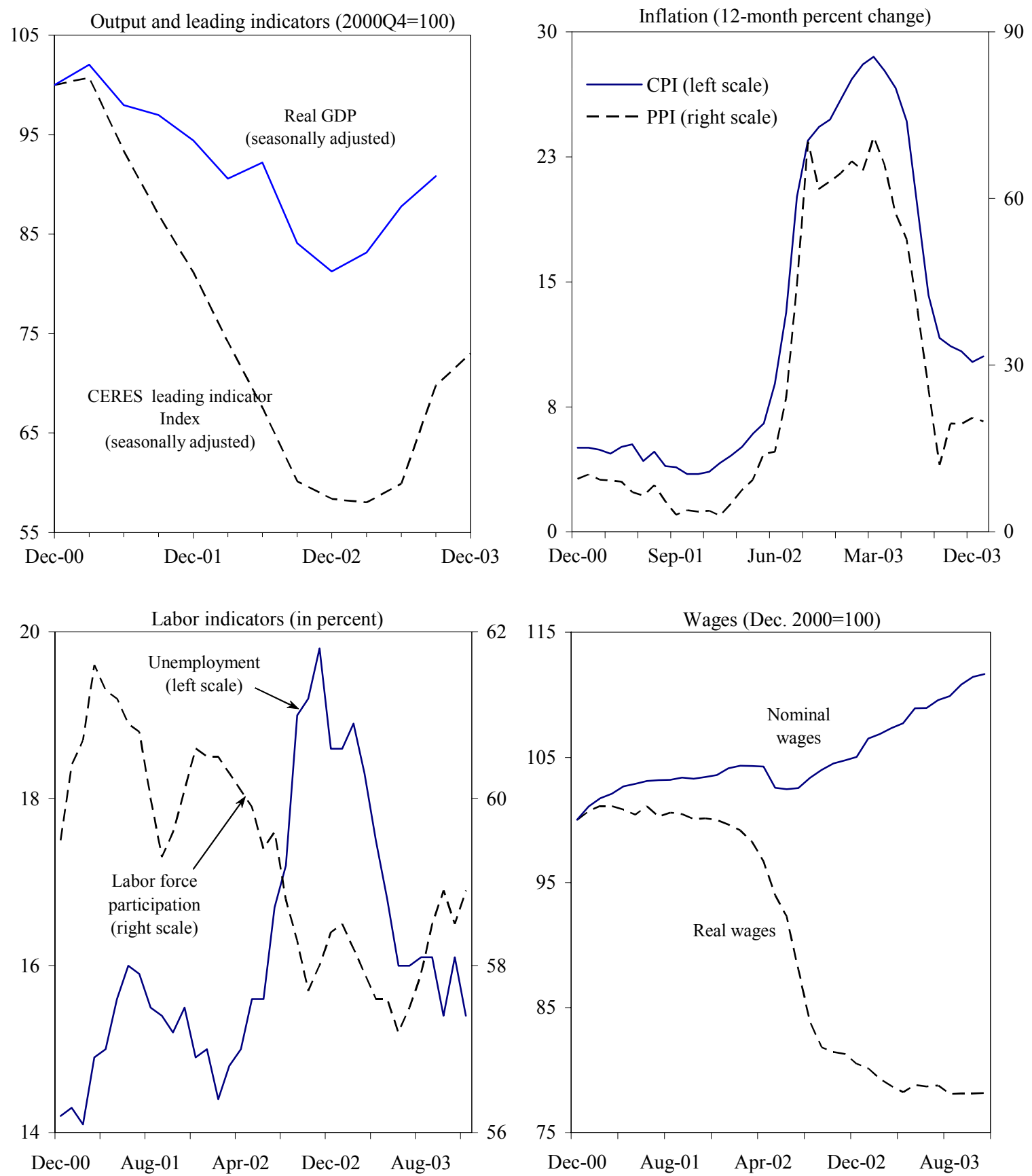

Sources: Central Bank of Uruguay; Ministry of Economy and Finance; CERES; and Fund staff estimates. 
Figure 2. Uruguay: External Sector Indicators
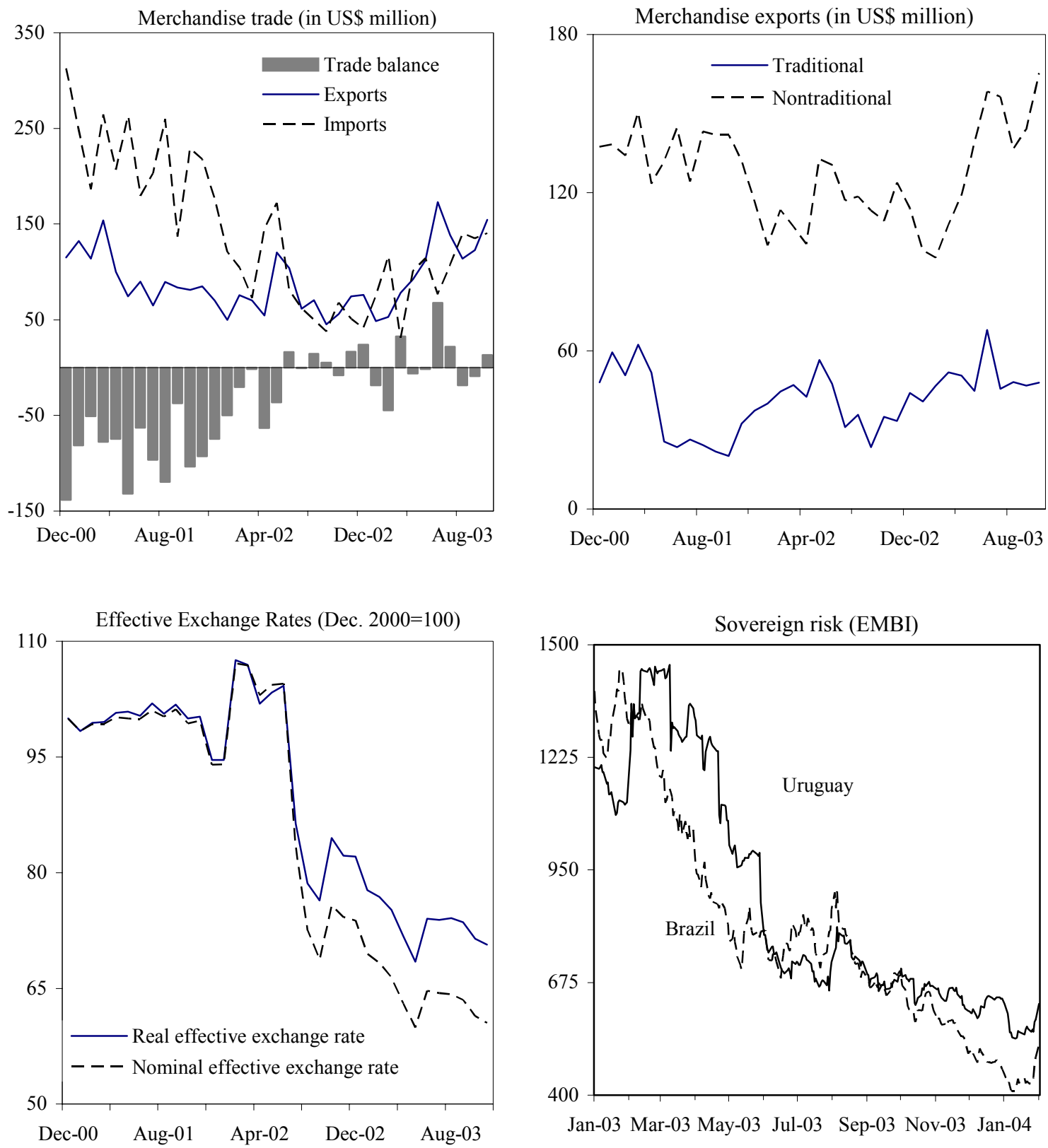

Sources: Central Bank of Uruguay; Ministry of Economy and Finance; CERES; and Fund staff estimates. 
Figure 3. Uruguay: Financial Indicators
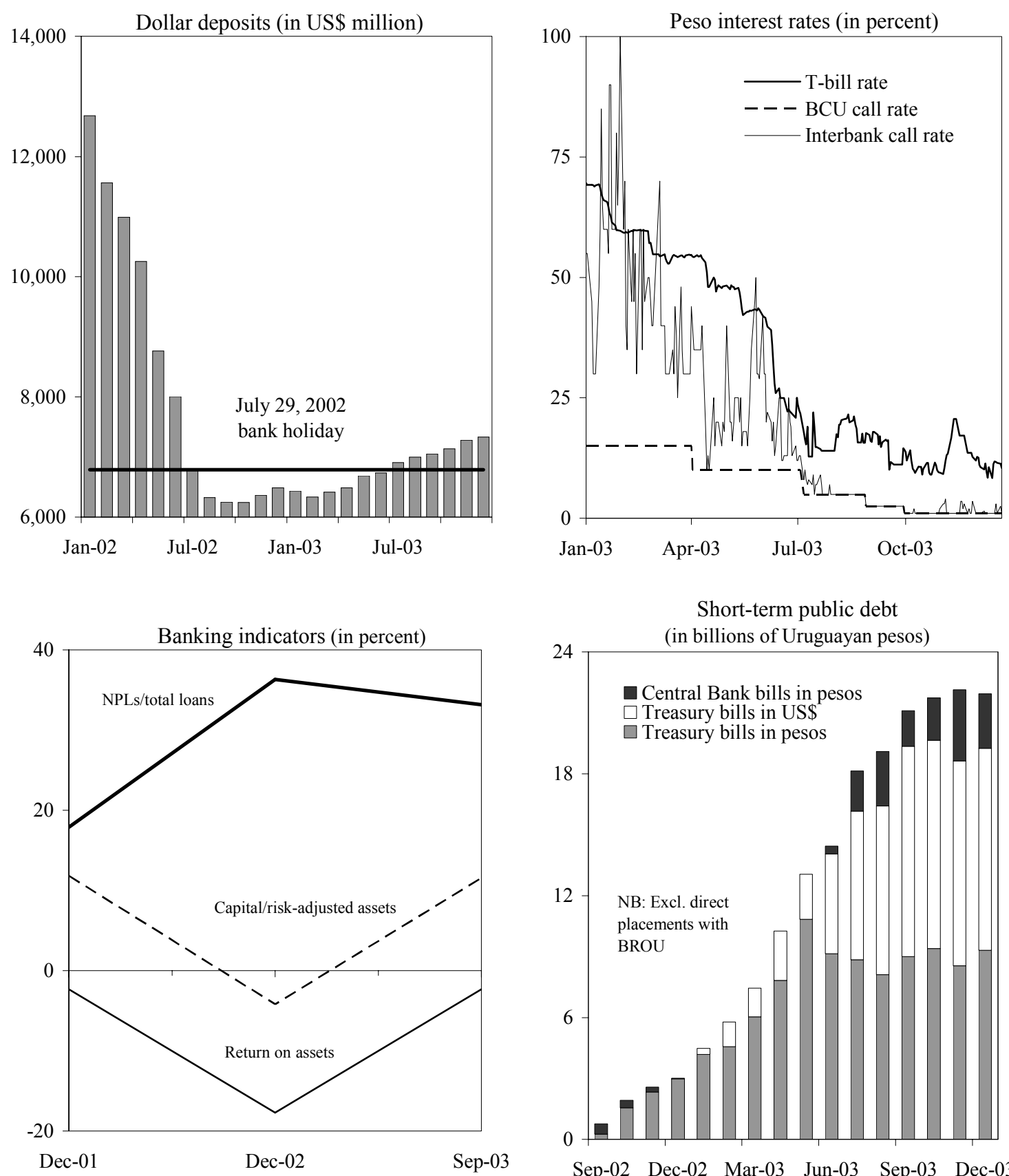

Short-term public debt

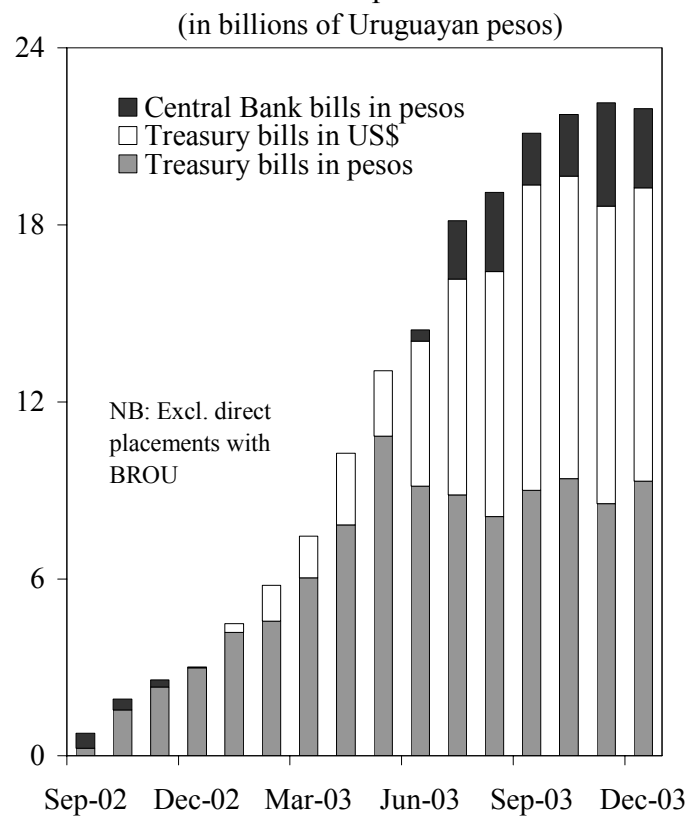

Sources: Central Bank of Uruguay; Ministry of Economy and Finance; and Fund staff estimates. 
Figure 4. Uruguay: Fiscal and Monetary Indicators
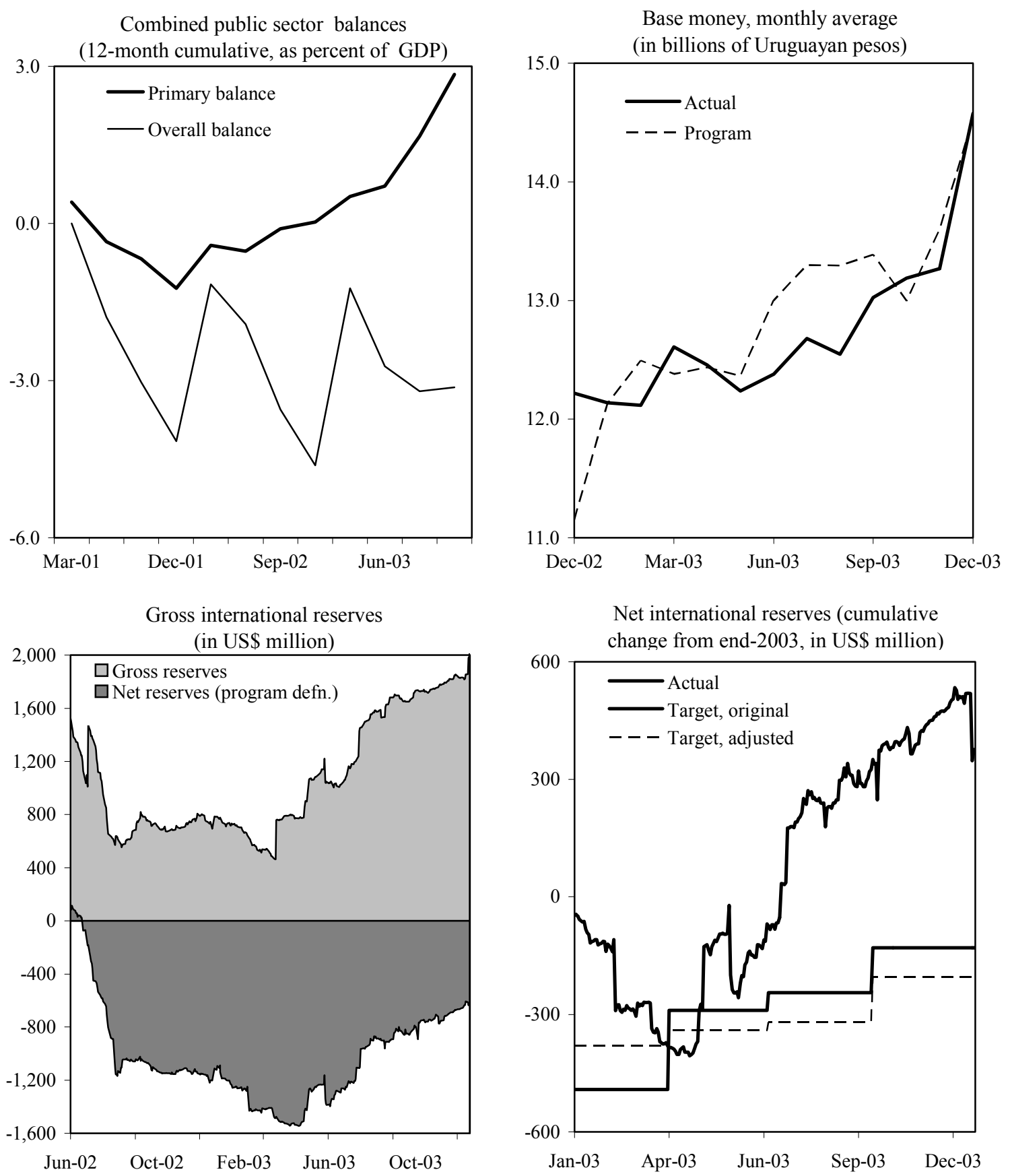

Source: Central Bank of Uruguay; Ministry of Economy and Finance; and Fund Staff estimates. 
Table 1. Uruguay: Selected Economic and Financial Indicators

\begin{tabular}{|c|c|c|c|c|c|c|}
\hline & \multirow[b]{2}{*}{2000} & \multirow[b]{2}{*}{2001} & \multirow[b]{2}{*}{2002} & Program & Est. & Proj. \\
\hline & & & & \multicolumn{2}{|c|}{2003} & 2004 \\
\hline \multicolumn{7}{|c|}{ (Percent change) } \\
\hline \multicolumn{7}{|l|}{ Output, prices, and wages } \\
\hline Real GDP & -1.4 & -3.4 & -10.8 & -1.0 & 1.0 & 5.0 \\
\hline Contributions to growth (percent) & & & & $\ldots$ & & \\
\hline Consumption & -1.3 & -2.2 & -15.6 & $\ldots$ & 1.7 & 4.0 \\
\hline Investment & -2.2 & -1.4 & -4.5 & $\ldots$ & -1.7 & 1.4 \\
\hline Net exports & 2.2 & 0.3 & 9.3 & $\ldots$ & 1.1 & -0.5 \\
\hline GDP deflator & 4.0 & 6.1 & 17.8 & 23.6 & 20.7 & 8.2 \\
\hline \multicolumn{7}{|l|}{ CPI inflation } \\
\hline Average & 4.8 & 4.4 & 14.0 & 23.2 & 19.4 & 7.9 \\
\hline End of period & 5.1 & 3.6 & 25.9 & 20.0 & 10.2 & 7.7 \\
\hline \multicolumn{7}{|l|}{ Exchange rate change (Ur\$/US\$) } \\
\hline Average & 6.7 & 10.1 & 62.1 & $\ldots$ & 32.2 & $\ldots$ \\
\hline End of period & 7.7 & 18.0 & 84.2 & $\ldots$ & 7.7 & $\ldots$ \\
\hline Public sector wage rates (end of period) & 2.9 & 5.1 & 0.5 & 7.2 & 7.9 & $\ldots$ \\
\hline \multicolumn{7}{|l|}{ GDP } \\
\hline In Ur\$ billions & 243.0 & 249.2 & 262.0 & 320.7 & 319.4 & 363.0 \\
\hline In US\$ billions & 20.1 & 18.7 & 12.1 & 10.6 & 11.3 & 12.1 \\
\hline \multicolumn{7}{|l|}{ Monetary indicators 1/ } \\
\hline Currency issued & -3.9 & -0.2 & 5.8 & 18.3 & 22.4 & 15.5 \\
\hline M-2 & 3.5 & 0.6 & -5.1 & 19.9 & 9.6 & 14.4 \\
\hline M-3 & 10.2 & 19.6 & 15.8 & 11.9 & 17.5 & 14.5 \\
\hline Credit to the private sector (constant exch. rate) & 0.3 & -3.8 & -17.6 & -5.3 & $-19.92 /$ & 1.6 \\
\hline \multicolumn{7}{|c|}{ (Percent of GDP, unless otherwise indicated) } \\
\hline \multicolumn{7}{|l|}{ Public sector operations } \\
\hline Revenue & 31.2 & 32.4 & 31.0 & 31.1 & 30.8 & 30.6 \\
\hline Noninterest expenditure (incl. discrepancy) & 32.7 & 33.6 & 30.9 & 28.1 & 28.0 & 27.4 \\
\hline Primary balance & -1.5 & -1.2 & 0.0 & 3.0 & 2.8 & 3.2 \\
\hline Interest & 2.6 & 2.9 & 4.6 & 6.6 & 6.0 & 6.5 \\
\hline Overall balance & -4.1 & -4.1 & -4.6 & -3.6 & -3.1 & -3.3 \\
\hline \multicolumn{7}{|l|}{ Savings and investment } \\
\hline Gross domestic investment & 14.0 & 13.7 & 12.2 & 11.8 & 10.7 & 11.1 \\
\hline Gross national savings & 11.1 & 10.8 & 13.8 & 13.8 & 10.9 & 11.7 \\
\hline Foreign savings & 2.8 & 2.8 & -1.6 & -2.1 & -0.3 & -0.7 \\
\hline \multicolumn{7}{|l|}{ External indicators } \\
\hline Merchandise exports, fob (US\$ millions) & 2,384 & 2,144 & 1,934 & 2,129 & 2,263 & 2,455 \\
\hline Merchandise imports, fob (US\$ millions) & 3,311 & 2,914 & 1,872 & 1,849 & 2,084 & 2,292 \\
\hline Merchandise terms of trade (percentage change) & -6.6 & -0.7 & 4.8 & 0.0 & 3.3 & 2.0 \\
\hline Current account balance (US\$ millions) & -566 & -533 & 191 & 219 & 31 & 80 \\
\hline Overall balance of payments (US\$ millions) 3/ & 167 & 302 & $-2,323$ & 220 & 1,303 & 700 \\
\hline Public debt (in percent of GDP) 4/ & 45.5 & 53.8 & 93.8 & 108.0 & 108.2 & 104.6 \\
\hline External debt (in percent of GDP) $5 /$ & 44.3 & 47.8 & 87.2 & 101.4 & 96.0 & 95.6 \\
\hline Of which: External public debt & 30.3 & 31.1 & 68.6 & 85.7 & 82.0 & 82.3 \\
\hline Gross official reserves (US\$ millions) & 2,779 & 3,099 & 776 & 1,481 & 2,079 & 2,779 \\
\hline In months of imports of goods and services & 8.0 & 10.0 & 3.8 & 7.3 & 9.3 & 11.3 \\
\hline As percent of short-term debt $6 /$ & 108.9 & 114.7 & 31.8 & 60.0 & 104.0 & 137.0 \\
\hline REER (percentage depreciation -, e.o.p.) & -0.8 & -5.5 & -13.2 & $\ldots$ & $-14.0 \quad 7 /$ & $\ldots$ \\
\hline
\end{tabular}

Sources: Data provided by the Uruguayan authorities; and Fund staff estimates.

1/ Evaluated at program exchange rates for 2004.

2/ Part of the sharp drop is due to the removal of the three liquidated banks from the database in May 2003.

3/ Defined as changes in reserve assets.

4/ Defined for combined public sector.

5/ Excludes nonresident deposits.

6/ Residual maturity. Does not include nonresident deposits.

7/ As of November 2003. 
Table 2. Uruguay: Summary Balance of Payments

(In millions of U.S. dollars)

\begin{tabular}{|c|c|c|c|c|c|c|c|c|c|c|c|c|}
\hline & \multirow[b]{2}{*}{2001} & \multirow[b]{2}{*}{2002} & \multicolumn{5}{|c|}{2003} & \multicolumn{5}{|c|}{2004} \\
\hline & & & Q1 & Q2 & Q3 & Q4 & Year & Q1 & Q2 & Q3 & Q4 & Year \\
\hline Current account & -533 & 191 & $\mathbf{0}$ & 28 & -31 & 35 & 31 & 49 & 71 & -75 & 35 & $\mathbf{8 0}$ \\
\hline Goods and services & -447 & 196 & 122 & 115 & 31 & 71 & 338 & 152 & 112 & 17 & 59 & 339 \\
\hline Goods & -771 & 61 & 3 & 107 & 25 & 44 & 179 & -4 & 109 & 19 & 39 & 163 \\
\hline Exports & 2,144 & 1,934 & 455 & 602 & 582 & 624 & 2,263 & 494 & 653 & 631 & 677 & 2,455 \\
\hline Imports & 2,914 & 1,872 & 453 & 495 & 557 & 580 & 2,084 & 498 & 544 & 612 & 638 & 2,292 \\
\hline Services & 324 & 135 & 119 & 8 & 5 & 27 & 159 & 156 & 3 & -2 & 20 & 176 \\
\hline Exports & 1,132 & 727 & 252 & 158 & 162 & 177 & 749 & 301 & 169 & 170 & 185 & 825 \\
\hline Imports & 808 & 592 & 132 & 151 & 157 & 150 & 590 & 146 & 166 & 172 & 165 & 649 \\
\hline Income & -114 & -76 & -139 & -106 & -81 & -56 & -382 & -122 & -61 & -112 & -44 & -339 \\
\hline Current transfers & 28 & 70 & 17 & 19 & 20 & 20 & 75 & 20 & 20 & 20 & 20 & $\mathbf{8 0}$ \\
\hline Financial account & 794 & $-2,337$ & 11 & 349 & 583 & 328 & 1,272 & 91 & 22 & 308 & 199 & 620 \\
\hline Direct investment, net & 319 & 77 & 81 & 67 & 76 & 50 & 274 & 50 & 50 & $\mathbf{5 0}$ & 50 & 200 \\
\hline Portfolio investment, net & 553 & 415 & -70 & 145 & 54 & 231 & 361 & 13 & 25 & 12 & 20 & 71 \\
\hline Government securities & 324 & 171 & -70 & 145 & 54 & 231 & 361 & 13 & 25 & 12 & 20 & 71 \\
\hline Banks & 229 & 244 & 0 & 0 & 0 & 0 & 0 & 0 & 0 & 0 & 0 & 0 \\
\hline Other investment, net & -78 & $-2,828$ & $\mathbf{0}$ & 137 & 453 & 47 & 637 & 28 & -53 & 246 & 129 & 349 \\
\hline Loans & $-1,041$ & 1,290 & 371 & -52 & 167 & 17 & 503 & 188 & 49 & 237 & 49 & 523 \\
\hline Nonfinancial public sector & 182 & 633 & 91 & 246 & -27 & 99 & 409 & 67 & -45 & 47 & -45 & 24 \\
\hline Other, net (fin. derivatives) & 0 & 14 & 0 & 0 & 0 & 0 & 0 & 0 & 0 & 0 & 0 & 0 \\
\hline BCU / use ofIMF resources & -58 & 883 & 280 & -20 & 180 & -20 & 422 & 139 & 113 & 209 & 113 & 573 \\
\hline Of which: FSBS resources & 0 & -716 & 0 & 0 & 0 & 0 & 0 & 0 & 0 & 0 & 0 & 0 \\
\hline Banks & $-1,166$ & -240 & 0 & -278 & 14 & -63 & -327 & -19 & -19 & -19 & -19 & -75 \\
\hline Deposits & 1,004 & $-1,693$ & -291 & -62 & 75 & -130 & -408 & -34 & -5 & -2 & 34 & -7 \\
\hline Public banks & 302 & -110 & 0 & 0 & -65 & -210 & -275 & 105 & 105 & 0 & 0 & 210 \\
\hline Private banks & 701 & $-1,582$ & -291 & -62 & 140 & 80 & -134 & -139 & -110 & -2 & 34 & -217 \\
\hline Other flows, net & -41 & $-2,426$ & -80 & 251 & 210 & 160 & 542 & -126 & -97 & 11 & 46 & -167 \\
\hline Banks & -9 & -121 & 0 & 0 & 0 & 0 & 0 & 0 & 0 & 0 & 0 & 0 \\
\hline Nonfinancial private sector & -31 & -818 & 0 & -26 & 0 & 0 & -26 & -151 & -122 & -14 & 21 & -267 \\
\hline Foreign currency held outside banks & 0 & $-1,487$ & -80 & 277 & 210 & 160 & 568 & 25 & 25 & 25 & 25 & 100 \\
\hline Errors and omissions & 41 & -177 & $\mathbf{0}$ & $\mathbf{0}$ & $\mathbf{0}$ & $\mathbf{0}$ & $\mathbf{0}$ & $\mathbf{0}$ & $\mathbf{0}$ & $\mathbf{0}$ & $\mathbf{0}$ & $\mathbf{0}$ \\
\hline Overall balance & 302 & $-2,323$ & 11 & 377 & 552 & 363 & 1,303 & 140 & 93 & 233 & 234 & 700 \\
\hline Reserve assets (- increase) & -302 & 2,323 & -11 & -377 & -552 & -363 & $-1,303$ & -140 & -93 & -233 & -234 & -700 \\
\hline \multicolumn{13}{|l|}{ Memorandum items: } \\
\hline Current account balance (percent of GDP) & -2.8 & 1.6 & & & & & 0.3 & & & & & 0.7 \\
\hline Financial account balance (percent of GDP) & 4.2 & -19.3 & & & & & 11.2 & & & & & 5.1 \\
\hline Gross international reserves & 3,099 & 776 & 787 & 1,164 & 1,716 & 2,079 & 2,079 & 2,219 & 2,312 & 2,545 & 2,779 & 2,779 \\
\hline in months of imports of GNFS & 10.0 & 3.8 & & & & & 9.3 & & & & & 11.3 \\
\hline
\end{tabular}


Table 3. Uruguay: Performance Under the 2003 Economic Program 1/

\begin{tabular}{|c|c|c|c|c|c|c|c|c|}
\hline & \multicolumn{4}{|c|}{ March 31, 2003} & \multicolumn{4}{|c|}{ June 30,2003} \\
\hline & Target & Adj. Target & Actual & Margin (+) & Target & Adj. Target & Actual & Margin $(+)$ \\
\hline \multicolumn{9}{|l|}{ A. Quantitative performance criteria } \\
\hline & \multicolumn{8}{|c|}{ (In millions of Uruguayan pesos) } \\
\hline 1. Combined public sector primary balance (cumulative floor) $2 / 3 / 4$ / & 2,170 & 2,123 & 1,639 & -484 & 2,176 & 2,148 & 2,279 & 131 \\
\hline 2. General government noninterest expenditure (cumulative ceiling) 2/ & $\cdots$ & $\ldots$ & $\ldots$ & $\cdots$ & $\ldots$ & $\cdots$ & $\ldots$ & ... \\
\hline \multirow[t]{2}{*}{ 3. Change in the net domestic assets of the $\mathrm{BCU}$ (ceiling) 2/ } & 14,000 & 14,000 & 10,738 & 3,262 & 9,000 & 10,450 & 2,868 & 7,582 \\
\hline & \multicolumn{8}{|c|}{ (In millions of U.S. dollars) } \\
\hline $\begin{array}{l}\text { 4. Net international reserves of the BCU (- decrease) (cumulative floor) } \\
2 / 5 /\end{array}$ & -490 & -490 & -380 & 110 & -290 & -340 & -69 & 271 \\
\hline 5. Nonfinancial public sector gross debt (ceiling) $3 / 4 / 6$ / & 8,915 & 8,953 & 8,455 & 498 & 9,010 & 9,141 & 8,777 & 364 \\
\hline \multicolumn{9}{|l|}{ B. Indicative targets } \\
\hline & \multicolumn{8}{|c|}{ (In millions of Uruguayan pesos) } \\
\hline & $-3,385$ & $-3,473$ & $-3,956$ & -484 & $-7,864$ & $-8,838$ & $-8,707$ & 131 \\
\hline 1. Combined public sector overall balance (cumulative floor) $2 / 3 / 4 / 7 /$ & & & & & & & & \\
\hline 2. Change in the monetary base (ceiling) 8 / & 165 & 165 & 393 & -228 & 790 & 790 & 163 & 627 \\
\hline
\end{tabular}

\begin{tabular}{|c|c|c|c|c|c|c|c|c|}
\hline & \multicolumn{4}{|c|}{ September 30, 2003} & \multicolumn{4}{|c|}{ December 31, 2003} \\
\hline & Target & Adj. Target & Actual & Margin (+) & Target & Adj. Target & Est. & $\overline{\operatorname{Margin}(+)}$ \\
\hline \multicolumn{9}{|l|}{ A. Quantitative performance criteria } \\
\hline & \multicolumn{8}{|c|}{ (In millions of Uruguayan pesos) } \\
\hline 1. Combined public sector primary balance (cumulative floor) $2 / 3 / 4$ / & 5,727 & 5,680 & 5,321 & -360 & 9,331 & $\ldots$ & $\ldots$ & $\ldots$ \\
\hline 2. General government noninterest expenditure (cumulative ceiling) 2/ & 25,821 & 25,821 & 25,425 & 396 & 35,125 & $\ldots$ & $\ldots$ & $\cdots$ \\
\hline \multirow[t]{2}{*}{ 3. Change in the net domestic assets of the BCU (ceiling) 2/ } & 7,600 & 9,775 & $-8,729$ & 18,504 & 6,600 & 8,775 & $-8,142$ & 16,917 \\
\hline & \multicolumn{8}{|c|}{ (In millions of U.S. dollars) } \\
\hline $\begin{array}{l}\text { 4. Net international reserves of the BCU (- decrease) (cumulative floor) } \\
\text { 2/ } 5 /\end{array}$ & -245 & -320 & 325 & 645 & -130 & -205 & 376 & 581 \\
\hline 5. Nonfinancial public sector gross debt (ceiling) $3 / 4 / 6$ / & 9,088 & 9,104 & 8,783 & 321 & 9,100 & $\ldots$ & $\cdots$ & ... \\
\hline \multicolumn{9}{|l|}{ B. Indicative targets } \\
\hline & \multicolumn{8}{|c|}{ (In millions of Uruguayan pesos) } \\
\hline & $-9,982$ & $-9,875$ & $-10,234$ & -360 & $-10,720$ & $\ldots$ & $\ldots$ & $\ldots$ \\
\hline 1. Combined public sector overall balance (cumulative floor) $2 / 3 / 4 / 7 /$ & & & & & & & & \\
\hline 2. Change in the monetary base (ceiling) 8 / & 1,175 & 1,175 & 808 & 367 & 2,325 & 2,325 & 2,360 & -35 \\
\hline
\end{tabular}

Sources: Ministry of Economy and Finance of Uruguay; and Central Bank of Uruguay.

1/ As defined in the Technical Memorandum of Understanding.

2/ Cumulative changes from end-December 2002

3/ Adjusted upward/downward for changes in transfers to the AFAPs, as defined in the TMU.

4/ Preliminary figures.

5/ Adjusted upward/downward for changes in program disbursements from the World Bank and IDB, as defined in the TMU.

6/ All maturities. The 2002 base includes US\$294 million of unsecuritized debt arising from an agreement between the Ministry of Economy and Finance and BROU.

For September and December, the debt ceiling has been adjusted upwards to reflect the transfer of Brady bonds from the central bank to the government.

7/ Adjusted upward/downward for changes in interest payments, as defined in the TMU.

8/ Cumulative change from December 2002 average. 
Table 3. Uruguay: Performance Under the 2003 Economic Program (continued)

\begin{tabular}{|c|c|c|}
\hline & Date & Status \\
\hline \multicolumn{3}{|l|}{ C. Structural performance criteria } \\
\hline $\begin{array}{l}\text { 1. Presentation to Congress of revised tax reform } \\
\text { legislation. }\end{array}$ & End-June & Observed \\
\hline $\begin{array}{l}\text { 2. No banks to be opened or reopened unless they are viable } \\
\text { and meet all prudential norms. }\end{array}$ & Continuous & Observed \\
\hline $\begin{array}{l}\text { 3. Outsource to third parties the disposal of the assets of the } \\
\text { liquidated banks in at least two asset groups. }\end{array}$ & End-July & $\begin{array}{l}\text { Not observed. Reset as end-February } 2004 \\
\text { performance criterion. }\end{array}$ \\
\hline \multicolumn{3}{|l|}{ D. Structural benchmarks } \\
\hline $\begin{array}{l}\text { 1. Publication of monthly bank balance sheets with a two- } \\
\text { month lag. }\end{array}$ & Continuous $9 /$ & Observed \\
\hline $\begin{array}{l}\text { 2. Agreement between the BROU, the government, and the } \\
\text { central bank on a reform plan for BROU. }\end{array}$ & End-August & Observed with delay. \\
\hline $\begin{array}{l}\text { 3. Approval by Congress of the reform of pension funds for } \\
\text { the police. }\end{array}$ & September 15 & Not observed. Reset as end-June 2004 benchmark. \\
\hline $\begin{array}{l}\text { 4. Approval by Congress of the reform of the pension funds } \\
\text { for the military. }\end{array}$ & End-September & Not observed. Reset as end-June 2004 benchmark. \\
\hline 5. Completion of the external audit of the FSBS. & End-September & $\begin{array}{l}\text { Partly observed. Reconciliation of recipient banks' } \\
\text { balance sheets is pending. }\end{array}$ \\
\hline 6. Submission of data to the SDDS for publication. & End-September & Partly observed. \\
\hline $\begin{array}{l}\text { 7. Presentation to Congress of the reform of the pension } \\
\text { system for bank employees. }\end{array}$ & End-December & $\begin{array}{l}\text { Not observed. Reset as end-December } 2004 \\
\text { benchmark. }\end{array}$ \\
\hline $\begin{array}{l}\text { 8. Issuance of decree or regulations to foster competition in } \\
\text { the oil sector. }\end{array}$ & End-December & $\begin{array}{l}\text { Observed. These regulations were unrelated to the } \\
\text { ANCAP law that was repealed by referendum in } \\
\text { December. }\end{array}$ \\
\hline
\end{tabular}

Sources: Ministry of Economy and Finance of Uruguay; and Central Bank of Uruguay.

9/ Beginning with data for March 31, 2003. 
Table 4. Uruguay: Combined Public Sector Operations

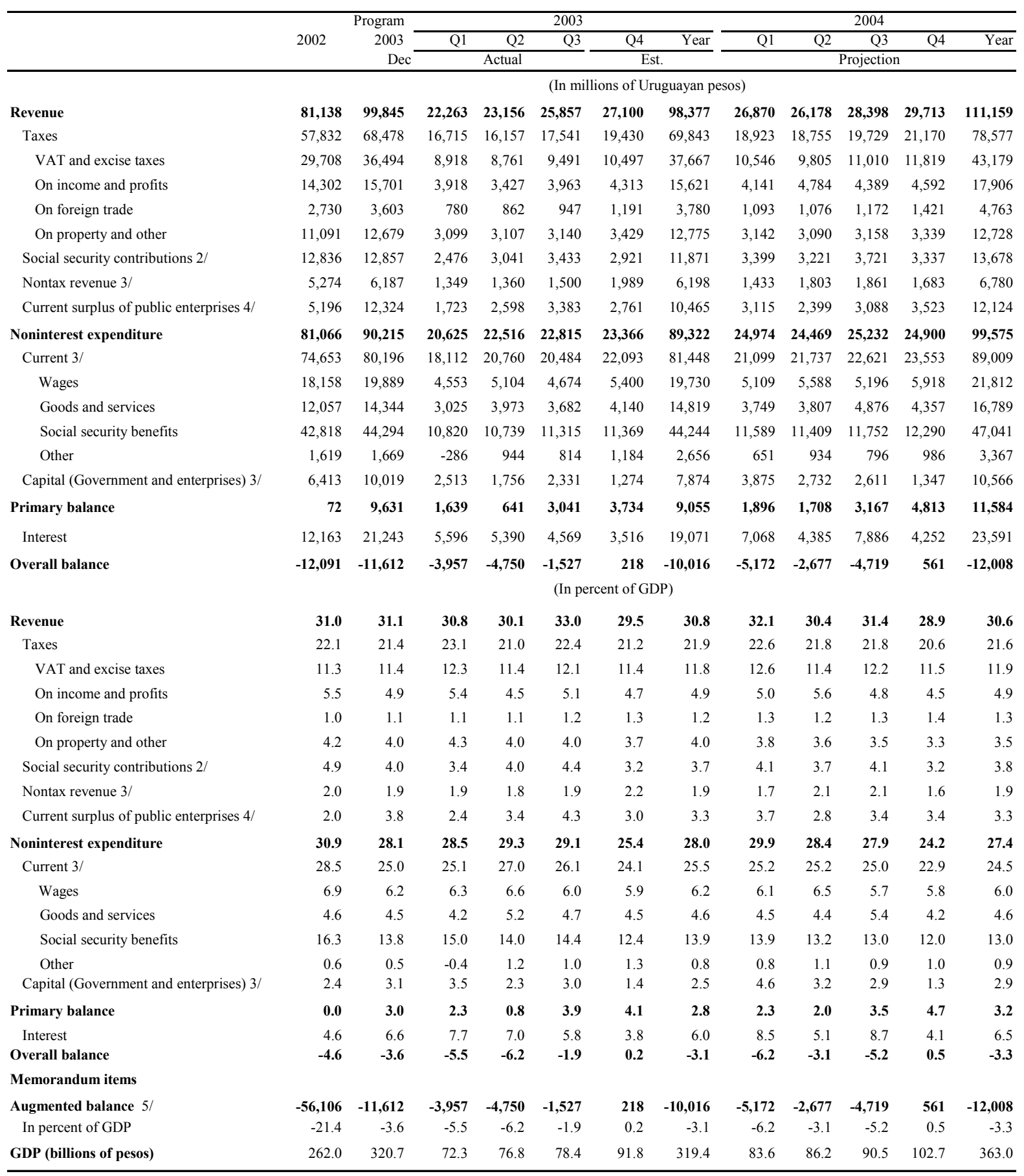

Sources: Ministry of Finance; and Fund staff estimates.

1/ Program figures including extra budgetary operations.

2/ Excludes contributions that are transferred to the private pension funds.

3/ Includes extrabudgetary operations from 1998.

4/ Includes transfers central government transfers to BPS, Caja Militar and Caja Policial.

5/ Includes the following bank-restructuring costs: US\$ 33 million of capital transfers for bank recapitalization, US\$ 564 million of liquidity supplied by BCU,

US\$ 444 million for the Fondo de Fortalecimiento del Sistema Bancario (FFSB), and US \$ 993 million for the FSBS. 
Table 5. Uruguay: Cash Flow of the Nonfinancial Public Sector (In millions of U.S. dollars)

\begin{tabular}{|c|c|c|c|c|c|c|c|c|c|c|c|c|}
\hline & \multirow[b]{2}{*}{2001} & \multirow[b]{2}{*}{2002} & \multicolumn{5}{|c|}{2003 Estimate } & \multicolumn{5}{|c|}{2004 Projection } \\
\hline & & & Q1 & Q2 & Q3 & Q4 & Year & Q1 & Q2 & Q3 & Q4 & Year \\
\hline Gross outflows & 1,200 & 3,278 & 386 & 326 & 165 & 185 & 1,063 & 224 & 238 & 183 & 119 & 763 \\
\hline Augmented deficit, NFPS & 700 & 2,510 & 129 & 177 & 27 & -17 & 315 & 136 & 63 & 101 & -55 & 244 \\
\hline Primary deficit & 170 & -14 & -62 & -32 & -114 & -124 & -332 & -70 & -64 & -112 & -167 & -413 \\
\hline Interest payments & 530 & 526 & 191 & 209 & 140 & 107 & 647 & 215 & 127 & 212 & 111 & 667 \\
\hline Bank assistance & 0 & 1,998 & 0 & 0 & 0 & 171 & 171 & 32 & 54 & 31 & 54 & 170 \\
\hline Bank asset recovery & 0 & 0 & 0 & 0 & 0 & -171 & -171 & -42 & -54 & -31 & -54 & -180 \\
\hline Amortization & 500 & 768 & 257 & 150 & 139 & 202 & 748 & 88 & 174 & 82 & 174 & 519 \\
\hline Long-term bonds & 403 & 349 & 196 & 45 & 3 & 13 & 257 & 13 & 1 & 10 & 1 & 25 \\
\hline Commercial banks & 0 & 214 & 13 & 40 & 57 & 107 & 217 & 6 & 12 & 7 & 12 & 38 \\
\hline Official loans (IDB, WB, others) & 97 & 205 & 49 & 64 & 60 & 62 & 234 & 69 & 66 & 65 & 65 & 265 \\
\hline $\mathrm{IMF}$ & 0 & 0 & 0 & 0 & 20 & 20 & 40 & 0 & 96 & 0 & 96 & 192 \\
\hline Gross inflows & 1,199 & 3,278 & 386 & 326 & 165 & 185 & 1,063 & 224 & 238 & 183 & 119 & 763 \\
\hline Short-term bills (net) 3/ & -32 & 383 & 113 & 18 & 171 & -58 & 244 & -144 & -17 & 100 & 86 & 25 \\
\hline Long-term bonds & 1,292 & 143 & 27 & 178 & 0 & 200 & 405 & 125 & 122 & 0 & 0 & 246 \\
\hline Commercial bank & 85 & 0 & -64 & 1 & -25 & -200 & -288 & 100 & 100 & 0 & 0 & 200 \\
\hline Central bank credit (net) & 7 & 665 & 347 & -73 & 25 & -1 & 297 & 0 & 0 & 0 & 0 & 0 \\
\hline Official loans (IDB, WB, Others) & 198 & 789 & 13 & 254 & 20 & 179 & 467 & 143 & 33 & 83 & 33 & 292 \\
\hline $\mathrm{IMF}$ & 0 & 1,302 & 0 & 0 & 0 & 0 & 0 & 0 & 0 & 0 & 0 & 0 \\
\hline Other inflows 3 / & -351 & -3 & -49 & -52 & -26 & 65 & -62 & 0 & 0 & 0 & 0 & 0 \\
\hline Residual financing needs & $\mathbf{0}$ & $\mathbf{0}$ & $\mathbf{0}$ & $\mathbf{0}$ & $\mathbf{0}$ & $\mathbf{0}$ & $\mathbf{0}$ & $\mathbf{0}$ & $\mathbf{0}$ & $\mathbf{0}$ & $\mathbf{0}$ & $\mathbf{0}$ \\
\hline
\end{tabular}

1/ Includes release of principal and cash payments due to debt exchange.

2/ Held outside the banking system.

3/ Includes use of financial assets, assistance bonds to banks, and intra-quarter float. 
Table 6. Uruguay: Summary Accounts of the Banking System 1/ (In millions of Uruguayan pesos, unless otherwise indicated)

\begin{tabular}{|c|c|c|c|c|c|c|c|c|c|c|}
\hline & \multirow{2}{*}{$\begin{array}{c}2001 \\
\text { Dec. }\end{array}$} & \multirow{2}{*}{$\begin{array}{l}2002 \\
\text { Dec. }\end{array}$} & \multicolumn{4}{|c|}{2003} & \multicolumn{4}{|c|}{2004} \\
\hline & & & Mar. & Jun. & \multicolumn{2}{|c|}{$\begin{array}{r}\text { Sept. } \\
\text { Est. }\end{array}$} & \multicolumn{4}{|c|}{$\begin{array}{l}\text { Jun. } \\
\text { Projections }\end{array}$} \\
\hline \multicolumn{11}{|c|}{ 1. Banco Central del Uruguay } \\
\hline Net foreign assets & 40,358 & $-18,747$ & $-30,188$ & $-14,092$ & $-6,313$ & $-1,746$ & $-1,414$ & $-1,620$ & -336 & 3,798 \\
\hline (in US\$ million) & 2,733 & -689 & $-1,045$ & -522 & -225 & -60 & -46 & -52 & -11 & 123 \\
\hline Net international reserves & 43,652 & $-5,374$ & $-13,786$ & $-2,851$ & 6,538 & 16,772 & 18,023 & 17,661 & 18,791 & 22,770 \\
\hline (in US\$ million) & 2,956 & -198 & -477 & -106 & 233 & 572 & 581 & 570 & 606 & 735 \\
\hline Other net foreign assets & $-3,294$ & $-13,373$ & $-16,402$ & $-11,241$ & $-12,850$ & $-18,517$ & $-19,437$ & $-19,282$ & $-19,127$ & $-18,972$ \\
\hline (in US\$ million) & -223 & -492 & -568 & -416 & -459 & -632 & -627 & -622 & -617 & -612 \\
\hline Net domestic assets & $-27,707$ & 30,464 & 41,097 & 25,908 & 17,230 & 16,387 & 14,651 & 14,946 & 13,881 & 12,894 \\
\hline Credit to the public sector & $-3,454$ & 41,919 & 67,109 & 60,712 & 63,838 & 68,722 & 70,464 & 63,748 & 67,030 & 72,158 \\
\hline Credit to the financial system & $-27,179$ & $-9,340$ & $-33,761$ & $-39,795$ & $-51,430$ & $-56,241$ & $-51,021$ & $-51,328$ & $-58,133$ & $-53,815$ \\
\hline Credit to the private sector & 284 & 2,163 & 2,052 & 2,051 & 2,043 & 2,067 & 2,086 & 2,106 & 2,137 & 2,168 \\
\hline Other & 2,642 & $-4,279$ & 5,697 & 2,940 & 2,779 & 1,840 & $-6,878$ & 419 & 2,846 & $-7,617$ \\
\hline Monetary liabilities & 12,651 & 11,717 & 10,909 & 11,815 & 10,918 & 14,641 & 13,237 & 13,325 & 13,545 & 16,692 \\
\hline Currency issued & 9,449 & 10,001 & 9,332 & 9,355 & 9,421 & 12,244 & 10,701 & 10,786 & 11,002 & 14,147 \\
\hline Currency in circulation & 7,095 & 7,673 & 7,096 & 7,069 & 7,123 & 8,014 & 8,218 & 8,271 & 8,405 & 9,281 \\
\hline Vault cash & 2,354 & 2,328 & 2,236 & 2,286 & 2,298 & 4,231 & 2,482 & 2,515 & 2,597 & 4,865 \\
\hline Private sector deposits & 3,203 & 1,716 & 1,577 & 2,460 & 1,496 & 2,397 & 2,537 & 2,540 & 2,543 & 2,546 \\
\hline \multicolumn{11}{|c|}{ 2. Public and Private Banks 2/ } \\
\hline Net foreign assets & $-10,313$ & 14,995 & $-1,039$ & 9,350 & 19,617 & 21,222 & 12,412 & 21,450 & 22,964 & 22,964 \\
\hline (in US\$ million) & -698 & 551 & -36 & 346 & 701 & 724 & 400 & 692 & 741 & 741 \\
\hline Net domestic assets & 144,429 & 142,908 & 170,775 & 166,196 & 158,930 & 165,003 & 189,170 & 185,530 & 185,657 & 190,349 \\
\hline Credit to the public sector & 10,082 & 10,854 & 14,135 & 13,995 & 16,367 & 16,596 & 16,215 & 15,835 & 15,454 & 15,073 \\
\hline Credit to the financial system & 25,880 & 4,601 & 38,191 & 48,521 & 47,944 & 43,914 & 44,920 & 44,765 & 44,767 & 45,324 \\
\hline Credit to the private sector & 133,636 & 171,869 & 151,810 & 138,381 & 136,915 & 145,875 & 158,509 & 154,248 & 150,616 & 154,809 \\
\hline Other & $-25,169$ & $-44,416$ & $-33,360$ & $-34,701$ & $-42,296$ & $-41,383$ & $-30,475$ & $-29,318$ & $-25,179$ & $-24,857$ \\
\hline Liabilities to the private sector (residents) & 134,116 & 157,903 & 169,735 & 175,546 & 178,548 & 186,225 & 201,582 & 206,980 & 208,621 & 213,313 \\
\hline Public banks & 65,978 & 85,398 & 95,386 & 97,430 & 94,738 & 98,942 & 105,723 & 107,088 & 104,695 & 105,353 \\
\hline Local currency & 9,863 & 9,212 & 12,019 & 12,675 & 11,798 & 12,151 & 12,809 & 13,467 & 14,125 & 14,783 \\
\hline Foreign currency & 56,116 & 76,186 & 83,367 & 84,755 & 82,940 & 86,791 & 92,914 & 93,621 & 90,570 & 90,570 \\
\hline Private banks & 68,138 & 72,505 & 74,350 & 78,116 & 83,810 & 87,283 & 95,859 & 99,893 & 103,926 & 107,959 \\
\hline Local currency & 11,070 & 9,699 & 7,693 & 8,860 & 8,994 & 8,994 & 9,065 & 9,136 & 9,207 & 9,278 \\
\hline Foreign currency & 57,067 & 62,805 & 66,657 & 69,255 & 74,816 & 78,289 & 86,794 & 90,757 & 94,719 & 98,682 \\
\hline \multicolumn{11}{|c|}{ 3. Banking System } \\
\hline Net foreign assets & 30,045 & $-3,752$ & $-31,227$ & $-4,743$ & 13,305 & 19,477 & 10,998 & 19,830 & 22,628 & 26,762 \\
\hline (in US\$ million) & 2,034 & -138 & $-1,081$ & -176 & 475 & 665 & 355 & 640 & 730 & 863 \\
\hline Net domestic assets & 114,369 & 171,044 & 209,636 & 189,818 & 173,862 & 177,159 & 201,339 & 197,961 & 196,941 & 198,378 \\
\hline Credit to the public sector & 6,628 & 52,774 & 81,243 & 74,707 & 80,205 & 85,318 & 86,680 & 79,582 & 82,484 & 87,231 \\
\hline Credit to the rest of financial system & $-3,651$ & $-7,067$ & 2,194 & 6,440 & $-5,784$ & $-8,096$ & $-3,619$ & $-4,048$ & $-10,768$ & $-3,625$ \\
\hline Credit to the private sector & 133,920 & 174,032 & 153,862 & 140,432 & 138,958 & 147,942 & 160,595 & 156,355 & 152,753 & 156,977 \\
\hline Local currency & 42,037 & 36,325 & 34,676 & 33,335 & 32,488 & 33,853 & 35,166 & 33,428 & 33,288 & 34,716 \\
\hline Foreign currency & 91,883 & 137,707 & 119,185 & 107,097 & 106,470 & 114,088 & 125,429 & 122,926 & 119,465 & 122,261 \\
\hline Other & $-22,528$ & $-48,695$ & $-27,663$ & $-31,761$ & $-39,517$ & $-39,543$ & $-37,353$ & $-28,899$ & $-22,334$ & $-32,474$ \\
\hline Broad money (M3) 3/ & 144,414 & 167,292 & 178,408 & 185,075 & 187,167 & 196,635 & 212,337 & 217,791 & 219,569 & 225,140 \\
\hline Currency outside banks & 7,095 & 7,673 & 7,096 & 7,069 & 7,123 & 8,014 & 8,218 & 8,271 & 8,405 & 9,281 \\
\hline Residents' deposits & 137,319 & 159,619 & 171,313 & 178,006 & 180,044 & 188,622 & 204,119 & 209,520 & 211,164 & 215,858 \\
\hline Local currency & 20,969 & 18,960 & 19,757 & 21,576 & 20,841 & 21,179 & 21,911 & 22,643 & 23,375 & 24,107 \\
\hline Foreign currency & 116,350 & 140,659 & 151,555 & 156,430 & 159,204 & 167,443 & 182,208 & 186,877 & 187,789 & 191,751 \\
\hline \multicolumn{11}{|c|}{ (12-month percent change) } \\
\hline Currency issued & -0.2 & 5.8 & 12.5 & 16.6 & 7.2 & 22.4 & 14.7 & 15.3 & 16.8 & 15.5 \\
\hline \multicolumn{11}{|l|}{ Broad money } \\
\hline $\mathrm{M} 2=$ currency + peso deposits & 0.6 & -5.1 & 8.3 & 23.8 & 20.5 & 9.6 & 12.2 & 7.9 & 13.6 & 14.4 \\
\hline $\mathrm{M} 3=\mathrm{M} 2+$ residents' foreign currency deposits & 19.6 & 15.8 & 27.9 & 37.2 & 16.5 & 17.5 & 19.0 & 17.7 & 17.3 & 14.5 \\
\hline Credit to the private sector (const. exchange rate) & -3.8 & -17.6 & -30.1 & -29.3 & -27.6 & -19.9 & -1.2 & 0.0 & 1.6 & 1.6 \\
\hline Total deposits held by residents & 21.0 & 16.2 & 28.3 & 38.0 & 16.6 & 18.2 & 19.1 & 17.7 & 17.3 & 14.4 \\
\hline Local currency & 1.8 & -9.6 & 5.1 & 25.3 & 23.1 & 11.7 & 10.9 & 4.9 & 12.2 & 13.8 \\
\hline Foreign currency and indexed & 25.3 & 20.9 & 32.2 & 39.9 & 15.8 & 19.0 & 20.2 & 19.5 & 18.0 & 14.5 \\
\hline Memorandum items: & & & & & & & & & & \\
\hline Nonresident foreign currency deposits (US\$ million) & 6,608 & 2,525 & 2,114 & 2,164 & 1,832 & 2,248 & 2,252 & 2,260 & 2,265 & 2,281 \\
\hline Exchange rate of presentation & 14.8 & 27.2 & 28.9 & 27.0 & 28.0 & 29.3 & 31.0 & 31.0 & 31.0 & 31.0 \\
\hline Consumer price inflation (eop) & 3.6 & 25.9 & 28.5 & 24.6 & 11.6 & 10.2 & 7.7 & 7.9 & 7.5 & 7.7 \\
\hline
\end{tabular}

Sources: Central Bank of Uruguay; and Fund staff estimates.

1/ Presentation used for program monitoring. May differ from presentation and definitions used in IFS.

2/ The Banco de la Republica Oriental de Uruguay (BROU), Banco Hipotecario de Uruguay (BHU; mortgage institution), private banks, and cooperatives.

3/ Excludes nonresident deposits. 
Table 7. Uruguay: Medium-Term Outlook

\begin{tabular}{|c|c|c|c|c|c|c|c|}
\hline & \multirow[b]{2}{*}{2002} & \multirow{2}{*}{$\begin{array}{r}\text { Est. } \\
2003\end{array}$} & \multicolumn{5}{|c|}{ Projections } \\
\hline & & & 2004 & 2005 & 2006 & 2007 & 2008 \\
\hline \multicolumn{8}{|c|}{$\begin{array}{l}\text { 1. Output and prices } \\
\text { (percent change) }\end{array}$} \\
\hline Real GDP & -10.8 & 1.0 & 5.0 & 4.0 & 4.0 & 3.0 & 3.0 \\
\hline Real domestic demand & -18.0 & -0.1 & 5.4 & 4.8 & 4.8 & 3.5 & 3.5 \\
\hline Of which: consumption & -16.1 & 1.8 & 4.4 & 3.7 & 3.6 & 2.6 & 2.5 \\
\hline Consumer prices (end-of-period) & 25.9 & 10.2 & 7.7 & 7.5 & 7.0 & 6.5 & 4.7 \\
\hline Merchandise export prices & -7.9 & 9.0 & 1.0 & 0.0 & 0.0 & 0.0 & 0.0 \\
\hline Merchandise export volume & -3.3 & 7.1 & 8.5 & 6.0 & 6.0 & 5.0 & 5.0 \\
\hline Merchandise import prices & -12.1 & 4.0 & -1.0 & 0.0 & 0.0 & 0.0 & 0.0 \\
\hline Merchandise import volume & -26.4 & 2.5 & 10.0 & 8.0 & 8.0 & 6.0 & 6.0 \\
\hline Merchandise terms of trade & 4.8 & 3.3 & 2.0 & 0.0 & 0.0 & 0.0 & 0.0 \\
\hline \multicolumn{8}{|c|}{$\begin{array}{l}\text { 2. Savings and investment } \\
\text { (percent of GDP) }\end{array}$} \\
\hline Gross domestic investment & 12.2 & 10.7 & 11.1 & 11.7 & 12.3 & 12.7 & 13.2 \\
\hline Gross national savings & 13.8 & 10.9 & 11.7 & 12.7 & 13.3 & 13.6 & 13.8 \\
\hline Foreign savings & -1.6 & -0.3 & -0.7 & -1.1 & -1.0 & -0.9 & -0.7 \\
\hline \multicolumn{8}{|c|}{$\begin{array}{l}\text { 3. Combined public sector operations } \\
\text { (percent of GDP) }\end{array}$} \\
\hline Overall balance & -4.6 & -3.1 & -3.3 & -2.2 & -2.1 & -1.7 & -1.8 \\
\hline Primary balance & 0.0 & 2.8 & 3.2 & 3.3 & 3.3 & 3.8 & 3.8 \\
\hline Public sector debt & 93.8 & 108.2 & 104.6 & 99.6 & 92.8 & 87.8 & 84.3 \\
\hline \multicolumn{8}{|c|}{ 4. Reserve adequacy } \\
\hline \multicolumn{8}{|l|}{ Gross official reserves } \\
\hline In months of imports of goods and services & 3.8 & 9.3 & 11.3 & 11.0 & 9.8 & 9.3 & 8.0 \\
\hline \multicolumn{8}{|l|}{ In percent of short-term debt } \\
\hline excluding nonresident deposits & 31.8 & 104.0 & 137.0 & 140.0 & 133.1 & 133.4 & 119.8 \\
\hline including nonresident deposits & 16.3 & 48.6 & 63.1 & 63.1 & 58.1 & 56.1 & 48.6 \\
\hline \multicolumn{8}{|c|}{$\begin{array}{l}\text { 5. Balance of payments and other external indicators } \\
\text { (in millions of U.S. dollars) }\end{array}$} \\
\hline Current account balance & 191 & 31 & 80 & 141 & 145 & 137 & 112 \\
\hline Trade balance & 61 & 179 & 163 & 127 & 85 & 62 & 37 \\
\hline Exports, f.o.b. & 1,934 & 2,263 & 2,455 & 2,602 & 2,759 & 2,897 & 3,041 \\
\hline Imports, f.o.b. & 1,872 & 2,084 & 2,292 & 2,476 & 2,674 & 2,834 & 3,004 \\
\hline Nonfactor services & 135 & 159 & 176 & 174 & 170 & 177 & 178 \\
\hline Exports, f.o.b. & 727 & 749 & 825 & 875 & 927 & 980 & 1,029 \\
\hline Imports, f.o.b. & 592 & 590 & 649 & 701 & 757 & 802 & 850 \\
\hline Factor services (net) & -76 & -382 & -339 & -210 & -155 & -148 & -148 \\
\hline Transfers (net) & 70 & 75 & 80 & 50 & 45 & 45 & 45 \\
\hline Financial account & $-2,337$ & 1,272 & 620 & -18 & -234 & -118 & -388 \\
\hline Foreign direct investment, net & 77 & 274 & 200 & 200 & 250 & 250 & 250 \\
\hline Portfolio investment, net & 415 & 361 & 71 & -2 & 42 & 120 & 22 \\
\hline Other investment, net & $-2,828$ & 637 & 349 & -215 & -525 & -488 & -660 \\
\hline Errors and omissions & -177 & 0 & 0 & 0 & 0 & 0 & 0 \\
\hline Overall balance & $-2,323$ & 1,303 & 700 & 123 & -88 & 19 & -276 \\
\hline Reserve assets (- increase) & 2,323 & $-1,303$ & -700 & -123 & 88 & -19 & 276 \\
\hline \multicolumn{8}{|c|}{ (percent of GDP) } \\
\hline Current account balance & 1.6 & 0.3 & 0.7 & 1.1 & 1.0 & 0.9 & 0.7 \\
\hline Financial account & -19.3 & 11.2 & 5.1 & -0.1 & -1.6 & -0.7 & -2.3 \\
\hline Total external debt (excl. nonres. deposits) & 87.2 & 96.0 & 95.6 & 86.6 & 75.0 & 66.8 & 59.4 \\
\hline \multicolumn{8}{|c|}{ (percent of exports of goods and nonfactor services) } \\
\hline Total external debt (excl. nonres. deposits) & 397.6 & 361.4 & 353.1 & 329.0 & 297.7 & 273.5 & 246.6 \\
\hline Total external debt (incl. nonres. deposits) & 485.1 & 437.1 & 425.6 & 401.7 & 371.7 & 349.0 & 323.5 \\
\hline Debt service & 55.6 & 51.6 & 47.4 & 49.9 & 64.3 & 57.9 & 46.8 \\
\hline Of which: interest & 25.7 & 17.5 & 16.0 & 17.4 & 17.1 & 15.7 & 14.8 \\
\hline
\end{tabular}

Sources: Central Bank of Uruguay; and Fund staff estimates. 
Table 8. Uruguay: Proposed Schedule of Purchases

$$
\text { (In millions of SDRs) }
$$

Augmented, extended, and rephased Stand-By Arrangement

\begin{tabular}{|c|c|c|c|c|c|}
\hline \multicolumn{3}{|c|}{ Original schedule } & \multicolumn{3}{|c|}{ Proposed revision } \\
\hline Date & SDR & $\%$ quota & Date & SDR & $\%$ quota \\
\hline September 2003 & 93.2 & $\begin{array}{l}\text { 30.4 Completion of the fourth review and } \\
\text { observance of end-June } 2003 \\
\text { performance criteria }\end{array}$ & & & \\
\hline November 2003 & 93.2 & $\begin{array}{l}\text { 30.4 Completion of the fifth review and } \\
\text { observance of end-September } 2003 \\
\text { performance criteria }\end{array}$ & & & \\
\hline February 2004 & 93.2 & $\begin{array}{l}\text { 30.4 Completion of the sixth review and } \\
\text { observance of end-December } 2003 \\
\text { performance criteria }\end{array}$ & February 2004 & 93.2 & $\begin{array}{l}\text { 30.4 Completion of the fourth review and } \\
\text { observance of end-December } 2003 \\
\text { performance criteria }\end{array}$ \\
\hline May 2004 & 93.2 & $\begin{array}{l}\text { 30.4 Completion of the seventh review and } \\
\text { observance of end-March } 2004 \\
\text { performance criteria }\end{array}$ & May 2004 & 139.8 & $\begin{array}{l}\text { 45.6 Completion of the fifth review and } \\
\text { observance of end-March } 2004 \\
\text { performance criteria }\end{array}$ \\
\hline August 2004 & 93.2 & $\begin{array}{l}\text { 30.4 Completion of the eighth review and } \\
\text { observance of end-June } 2004 \\
\text { performance criteria }\end{array}$ & August 2004 & 139.8 & $\begin{array}{l}\text { 45.6 Completion of the sixth review and } \\
\text { observance of end-June } 2004 \\
\text { performance criteria }\end{array}$ \\
\hline November 2004 & 93.2 & $\begin{array}{l}\text { 30.4 Completion of the ninth review and } \\
\text { observance of end-September } 2004 \\
\text { performance criteria }\end{array}$ & November 2004 & 139.8 & $\begin{array}{l}\text { 45.6 Completion of the seventh review and } \\
\text { observance of end-September } 2004 \\
\text { performance criteria }\end{array}$ \\
\hline February 2005 & 93.2 & $\begin{array}{l}\text { 30.4 Completion of the tenth review and } \\
\text { observance of end-December } 2004 \\
\text { performance criteria }\end{array}$ & February 2005 & 139.8 & $\begin{array}{l}\text { 45.6 Completion of the eighth review and } \\
\text { observance of end-December } 2004 \\
\text { performance criteria }\end{array}$ \\
\hline
\end{tabular}

Source: Fund staff estimates. 
Table 9. Uruguay: Projected Payments to the Fund and Indicators of Capacity to Repay the Fund 1/

\begin{tabular}{|c|c|c|c|c|c|c|}
\hline & 2003 & 2004 & 2005 & 2006 & 2007 & 2008 \\
\hline \multicolumn{7}{|c|}{ Cumulative payments (existing and prospective; in SDR million) } \\
\hline Principal (repurchases) & 57.1 & 128.7 & 226.6 & 666.7 & 609.4 & 390.7 \\
\hline Charges and interest $2 /$ & 46.6 & 64.3 & 74.1 & 56.8 & 27.8 & 11.8 \\
\hline On Fund credit & 45.9 & 63.6 & 73.4 & 56.1 & 27.1 & 11.1 \\
\hline On use of SDRs & 0.7 & 0.7 & 0.7 & 0.7 & 0.7 & 0.7 \\
\hline Total obligations & 103.0 & 192.3 & 300.7 & 723.5 & 637.1 & 402.5 \\
\hline (percent of quota) & 33.6 & 62.7 & 98.1 & 236.0 & 207.9 & 131.3 \\
\hline \multicolumn{7}{|l|}{ Fund repurchases and charges } \\
\hline In millions of SDRs & 103.0 & 192.3 & 300.7 & 723.5 & 637.1 & 402.5 \\
\hline In millions of U.S. dollars & 143.9 & 270.4 & 421.9 & $1,013.2$ & 890.3 & 560.7 \\
\hline In percent of exports of goods and NFS & 4.8 & 8.2 & 12.1 & 27.5 & 23.0 & 13.8 \\
\hline In percent of GDP & 1.3 & 2.2 & 3.2 & 6.9 & 5.6 & 3.3 \\
\hline In percent of quota & 33.6 & 62.7 & 98.1 & 236.0 & 207.9 & 131.3 \\
\hline In percent of overall external debt service & 9.3 & 17.4 & 24.3 & 42.8 & 39.7 & 29.4 \\
\hline In percent of foreign reserves $1 /$ & 6.9 & 9.7 & 14.5 & 36.0 & 31.4 & 21.9 \\
\hline \multicolumn{7}{|l|}{ Fund credit outstanding (end of period) } \\
\hline In millions of SDRs & $1,625.9$ & $2,009.8$ & $1,923.0$ & $1,256.3$ & 647.0 & 256.3 \\
\hline In millions of U.S. dollars & $2,271.4$ & $2,825.6$ & $2,697.7$ & $1,759.5$ & 904.0 & 357.0 \\
\hline In percent of exports of goods and NFS & 75.4 & 86.1 & 77.6 & 47.7 & 23.3 & 8.8 \\
\hline In percent of GDP & 20.0 & 23.3 & 20.4 & 12.0 & 5.7 & 2.1 \\
\hline In percent of quota & 530.5 & 655.7 & 627.4 & 409.9 & 211.1 & 83.6 \\
\hline In percent of public sector external debt & 24.4 & 28.3 & 27.5 & 18.9 & 10.1 & 4.2 \\
\hline In percent of overall external debt & 20.9 & 24.4 & 23.6 & 16.0 & 8.5 & 3.6 \\
\hline In percent of foreign reserves & 109.2 & 101.7 & 93.0 & 62.5 & 31.9 & 14.0 \\
\hline \multicolumn{7}{|c|}{ Memorandum items (in millions of U.S. dollars unless otherwise noted): } \\
\hline Exports of goods and NFS & 3,012 & 3,280 & 3,477 & 3,686 & 3,876 & 4,070 \\
\hline Quota (Millions of SDRs) & 306.5 & 306.5 & 306.5 & 306.5 & 306.5 & 306.5 \\
\hline GDP & 11,342 & 12,117 & 13,210 & 14,632 & 15,861 & 16,900 \\
\hline U.S. dollar per SDR (WEO projection) & 1.3970 & 1.4059 & 1.4029 & 1.4005 & 1.3973 & 1.3930 \\
\hline Public sector debt & 12,276 & 12,670 & 13,156 & 13,585 & 13,933 & 14,255 \\
\hline Public sector external debt & 9,303 & 9,971 & 9,808 & 9,327 & 8,968 & 8,419 \\
\hline Overall external debt service & 1,555 & 1,554 & 1,735 & 2,369 & 2,245 & 1,905 \\
\hline of which: public debt service to all IFIs & 334 & 631 & 894 & 1,617 & 1,429 & 865 \\
\hline Overall external debt & 10,885 & 11,584 & 11,441 & 10,974 & 10,601 & 10,036 \\
\hline Foreign reserves & 2,079 & 2,779 & 2,902 & 2,813 & 2,832 & 2,557 \\
\hline
\end{tabular}

Sources: Finance Department; and Fund staff estimates and projections.

1/ Assuming that all scheduled purchases are made and that repurchases under the SBA and SRF are made on an obligations basis. On March 17, 2003, the IMF Executive Board converted the two remaining SRF repurchases to an obligations basis.

2/ Projections are based on current rates of charge, including burden-sharing where applicable, for purchases in the GRA. The current SDR interest rate is assumed for net use of SDRs. 
Table 10. Uruguay: Vulnerability Indicators

\begin{tabular}{rrrrrr}
\hline & 2000 & 2001 & 2002 & 2003 & 2004 \\
Est. & Proj. \\
\hline
\end{tabular}

(Percent change, unless otherwise indicated)

\section{Financial sector indicators}

Broad money

Credit to the private sector (const. exch. rate)

Share of nonperforming loans in total loans (in percent) $1 /$

Prime interest rates (percent, average) - domestic loans 2/

Prime interest rates, real (percent, average) - domestic loans 2/

$\begin{array}{rrrrr}10.2 & 19.6 & 15.8 & 17.5 & 14.5 \\ 0.3 & -3.8 & -17.6 & -19.9 & 1.6 \\ 16.4 & 17.0 & 36.3 & 33.2 & \ldots \\ 20.7 & 24.7 & \ldots & \ldots & \ldots \\ 14.9 & 20.4 & \ldots & \ldots & \ldots\end{array}$

\section{External Indicators}

Merchandise exports (in U.S. dollars)

Merchandise imports (in U.S. dollars)

Merchandise terms of trade

REER appreciation (+)

$\begin{array}{rrrrr}4.1 & -10.1 & -9.8 & 17.0 & 8.5 \\ 3.9 & -12.0 & -35.8 & 11.3 & 10.0 \\ -6.6 & -0.7 & 4.8 & 3.3 & 2.0 \\ -0.8 & -5.5 & -13.2 & -14.0 & \ldots\end{array}$

(Percent of GDP, unless otherwise indicated)

Current account balance

Capital and financial account balance

Of which: Net foreign direct investment

$\begin{array}{rrrrr}-2.8 & -2.8 & 1.6 & 0.3 & 0.7 \\ 3.8 & 4.2 & -19.3 & 11.2 & 5.1 \\ 1.4 & 1.7 & 0.6 & 2.4 & 1.7 \\ 1.5 & 3.0 & 3.4 & 3.2 & 0.6 \\ 1.0 & -0.4 & -23.3 & 5.6 & 2.9 \\ 72.7 & 85.3 & 106.4 & 116.1 & 115.2 \\ 30.3 & 31.1 & 68.6 & 82.0 & 82.3 \\ 28.4 & 37.6 & 19.2 & 20.1 & 19.6 \\ 399.1 & 487.4 & 485.1 & 437.1 & 425.6 \\ 44.3 & 47.8 & 87.2 & 96.0 & 95.6 \\ 243.0 & 272.8 & 397.6 & 361.4 & 353.1 \\ 21.7 & 23.7 & 25.7 & 17.5 & 16.0 \\ 14.4 & 19.7 & 29.9 & 34.2 & 31.4\end{array}$

Portfolio investment (securities etc.)

Other net inflows (deposits, loans, trade credits, etc.)

Total external debt including nonresident deposits

Of which: Public sector excl. nonresident deposits

Foreign currency deposits (nonresidents)

In percent of exports GNFS

Total external debt excluding nonresident deposits

In percent of exports GNFS

External interest payments to exports GNFS (in percent)

External amortization payments to exports GNFS (in percent)

(US\$ million, unless otherwise indicated)

Central Bank reserve liabilities

Short term foreign assets of the financial sector

Short term foreign liabilities of the financial sector

$\begin{array}{rrrrr}150 & 144 & 970 & 1,493 & \ldots \\ 7,367 & 7,695 & 3,140 & 3,804 & \ldots \\ 6,504 & 7,547 & 2,206 & 597 & \ldots \\ 2,779 & 3,099 & 776 & 2,079 & 2,779 \\ 8.0 & 10.0 & 3.8 & 9.3 & 11.3 \\ 210.2 & 217.8 & 52.4 & 133.7 & 178.8 \\ 27.8 & 28.6 & 10.0 & 30.8 & 37.8 \\ 365.9 & 483.0 & 203.8 & 446.5 & 546.6 \\ 33.6 & 31.8 & 16.3 & 48.6 & 63.1 \\ 108.9 & 114.7 & 31.8 & 104.0 & 137.0\end{array}$

Gross official reserves

In months of imports GNFS

In percent of total debt service

In percent of broad money

In percent of base money

In percent of short-term external debt incl. deposits 3/

In percent of short-term external debt excl. deposits 3/

\section{Financial Market Indicators}

Foreign currency debt rating (Moody's) 4/

Foreign currency debt rating (S\&P) 4/

Spread of benchmark bonds (basis points, end of period) 4/

$\begin{array}{rrrrr}\text { Baa3 } & \text { Baa3 } & \text { B3 } & \text { B3 } & \ldots \\ \text { BBB- } & \text { BBB- } & \text { B- } & \text { B- } & \ldots \\ 326.0 & 251.0 & 1,609.0 & 651.0 & \ldots \\ 12.1 & 13.3 & 21.6 & 28.2 & \ldots\end{array}$

Exchange rate (per U.S. dollar, period average)

Sources: Central Bank of Uruguay; and Fund staff estimates.

1/ For 2003, data are as of end-September.

2 / Due to the liquidation of several banks in the survey sample, this data series is no longer available.

$3 /$ By remaining maturity.

4/ For 2000, the data reported are the spread of the 2009 bond; for 2001-02, the 2012 bond; and for 2003, the 2033 bond. 
Montevideo, Uruguay

February 6, 2004

Dear Mr. Köhler:

Since the completion of the third review under the Stand-By Arrangement last July, the Uruguayan economy has continued to strengthen, and financial indicators have further improved. The government of Uruguay remains firmly committed to achieving the objectives of the program, through fiscal consolidation and structural reforms. Available data indicate that all quantitative performance criteria under the program for end-September have been observed, except for a small shortfall in the combined public sector primary balance, which was more than offset in the overall balance by lower interest payments.

The attached Memorandum of Economic and Financial Policies presents the policies of the government of Uruguay for 2004. In support of its program, the Government of Uruguay requests: (i) completion of the fourth review under the Stand-By Arrangement, with availability of a purchase equivalent to SDR 93.2 million; (ii) rephasing of all remaining purchases under the arrangement, in an amount equivalent to SDR 559.2 million (Table A); (iii) a waiver of nonobservance of the end-July 2003 structural performance criterion to outsource to third parties the disposal of the assets of liquidated banks in at least two asset groups; (iv) a waiver of nonobservance of the end-December 2003 quantitative performance criterion on the cumulative primary balance of the combined public sector; and (v) waivers of applicability of the end-December 2003 quantitative performance criteria on the nonfinancial public sector gross debt and on general government noninterest expenditure. These waivers are requested on the basis of the strong policies that will be maintained for 2004, in line with the original design of the program. We also request that the repurchase expectations arising during 2004 be moved to an obligations basis. There will be four program reviews in 2004, to be held in February, May, August, and November.

We are confident that the policies set out in the attached Memorandum will ensure the success of the program and justify the requested waivers and completion of the review. The continued support of the international financial institutions will be fundamental in 
underpinning economic recovery. The government stands ready, in consultation with the Fund, to take any additional measures necessary to ensure the success of the program.

Sincerely yours,

\author{
$/ \mathrm{s} /$ \\ Julio de Brun \\ President \\ Central Bank of Uruguay
}

\author{
$/ \mathrm{s} /$ \\ Isaac Alfie \\ Minister of Economy and Finance \\ Oriental Republic of Uruguay
}

Mr. Horst Köhler

Managing Director

International Monetary Fund

700 19th Street, N.W.

Washington, D.C. 20431

Attachments: Memorandum of Economic and Financial Policies

Technical Memorandum of Understanding

Table A. Schedule of Remaining Purchases Under the Stand-By Arrangement

(In millions of SDRs)

\begin{tabular}{|c|c|c|c|c|c|}
\hline \multicolumn{3}{|c|}{ Original schedule } & \multicolumn{3}{|c|}{ Revised schedule } \\
\hline$\overline{\text { Date }}$ & SDR & $\%$ quota & $\overline{\text { Date }}$ & SDR & $\%$ quota \\
\hline October 2003 & 93.2 & 30.4 & & & \\
\hline December 2003 & 93.2 & 30.4 & & & \\
\hline February 2004 & 93.2 & 30.4 & February 2004 & 93.2 & 30.4 \\
\hline May 2004 & 93.2 & 30.4 & May 2004 & 139.8 & 45.6 \\
\hline August 2004 & 93.2 & 30.4 & August 2004 & 139.8 & 45.6 \\
\hline November 2004 & 93.2 & 30.4 & November 2004 & 139.8 & 45.6 \\
\hline February 2005 & 93.2 & 30.4 & February 2005 & 139.8 & 45.6 \\
\hline
\end{tabular}




\section{Memorandum of Economic ANd Financial Policies For 2004}

\section{BACKGROUND}

1. In recent months, Uruguay's economy has gained significant strength and financial indicators have continued to improve. On a seasonally adjusted basis, real GDP expanded by over 3 percent (quarter-on-quarter) during each of the first three quarters of 2003, and partial data point to a further strengthening in activity during the fourth quarter. For 2003 as a whole, growth is estimated to be about 1 percent, reflecting strong export performance and a recovery in domestic demand. Inflation has declined to about 10 percent, bank deposits have continued to increase, and gross international reserves have risen fourfold since mid-March, to US $\$ 2.1$ billion at end-December (equivalent to $9 \frac{1}{4}$ months of imports of goods and services). All end-September quantitative performance criteria under the program have been observed, except for a small shortfall in the combined public sector primary balance, which was more than offset in the overall balance by lower interest payments.

\section{EConomic Program for 2004}

2. The government has laid out policies for 2004 aimed at consolidating the gains made in 2003, with a strong improvement in economic activity, a further reduction in inflation, and a strengthening in external balances. The economy is assumed to grow by 5 percent, led by the ongoing recovery in exports and domestic demand, and inflation is projected to decline to 7-9 percent by year-end. The external current account surplus would improve slightly in 2004 to about $1 / 2$ percent of GDP, and the program aims at a modest increase (US\$100 million) in net official international reserves.

3. Toward these ends, the program will maintain prudent fiscal and monetary policies and take further steps toward ensuring banking sector soundness, while adopting structural reforms to underpin medium-term growth. Its main components are: (i) the 2004 budget, which seeks to achieve a primary surplus of the combined public sector of 3.2 percent of GDP; (ii) a monetary program aimed at limiting base money growth to about 15 percent; and (iii) a deepening of the restructuring of the banking system, with emphasis on the public bank BROU. The performance criteria are set out in Table 1 and defined in the attached Technical Memorandum of Understanding, and Table 2 presents the prior actions and structural benchmarks under the program. The government will also observe the standard performance criteria regarding exchange restrictions, multiple currency practices, and import restrictions for balance of payments reasons.

\section{Fiscal ANd Monetary Policies}

4. The government is firmly committed to achieving the primary surplus objectives of the program, as a key component of our strategy to ensure debt sustainability. During 2003, the primary balance of the combined public sector improved significantly, shifting from equilibrium in 2002 to a surplus of close to 3 percent of GDP. Building on this achievement, the primary surplus is projected to increase to 3.2 percent of GDP in 2004, rise further to about 4 percent of GDP by 2007, and remain at about that level over the ensuing several 
years. To ensure debt sustainability, however, we will keep the adequacy of the fiscal surplus target under continuous review to ensure that it is sufficient to address the additional fiscal costs that could arise from contingent fiscal liabilities associated with the restructuring of the public banks. Over the medium term, if economic growth turns out to be significantly higher than presently envisaged, the government would be ready to further improve the primary surplus of the combined public sector, to ensure that the overall balance is in equilibrium.

5. In 2004, expenditure restraint will remain at the core of the fiscal program. In nominal terms, the growth in central government noninterest expenditure will be limited to about 9 percent, or close to projected inflation. This increase includes one-time expenses of about 0.4 percent of GDP to cover the cost of the national elections and provide for the payment of deferred expenditures, including food vouchers granted in 2003. Wage and pension increases will remain moderate, and the wage bill of the central government will amount to Ur\$15 billion in 2004. The program, however, allows for some room in discretionary spending if tax revenue turns out to be higher than envisaged, provided that the program objectives are met. Social expenditure will be protected, and capital expenditure is programmed to recover somewhat in 2004.

6. Revenue of the consolidated public sector is projected to increase slightly as a proportion of GDP, to 30.6 percent in 2004 . This performance will be supported by a current surplus of public enterprises of 3.3 percent of GDP (excluding interest), reflecting adjustments in public tariffs consistent with changes in operating costs. Steps have been taken to strengthen tax administration. To reduce evasion, responsibility for supervising the tax-free zones has been transferred from the Ministry of Economy and Finance to the Tax Administration Department (DGI). In November 2003, congress approved a law providing additional resources to the DGI and enhancing its ability to modernize its internal structure, in line with FAD technical assistance recommendations. As part of its modernization, the DGI will complete a master plan to reengineer its processes and systems, and will establish a Large Taxpayer Unit by end-September 2004 (a structural benchmark).

7. The government remains committed to a floating exchange rate policy. To improve the transparency of exchange market operations, the Central Bank of Uruguay (BCU) has separated its foreign exchange operations from those of the central government. In October, the BCU began conducting most of its foreign exchange operations through preannounced auctions on the electronic stock exchange.

8. The BCU will continue to implement monetary policy in line with targeting base money growth, to anchor inflation expectations and further enhance monetary policy credibility, thereby paving the way for future adoption of inflation targeting. For 2004, base money is targeted to grow by 15 percent, consistent with the macroeconomic framework and a moderation of the remonetization process. Quarterly base money targets are being announced, in line with the desired annual path, and short-term monetary instruments are being used to minimize intra-month volatility. To improve the transparency of monetary policy, the BCU will continue to publish daily information on base money developments. In January 2004, the BCU initiated a regular survey of inflation expectations. The BCU will also continue to promote the use of peso instruments, including inflation-indexed notes. The NDA and NIR performance criteria of the program are presented in Table 1. 


\section{Restructuring OF THE BANKING SyStem.}

9. Reform of the public banks and disposal of the remaining assets in the liquidation funds are key priorities under the 2004 program. A comprehensive plan for restructuring BROU was finalized in December 2003. The main elements of this plan are to: (i) strengthen BROU's commercial focus and redirect its operations toward business segments where it has a competitive advantage; (ii) improve credit risk management and loan monitoring;

(iii) reduce operating costs through the implementation of a rationalization plan; and

(iv) provide for the phased removal of nonperforming loans. Progress in the implementation of this plan, designed to ensure BROU's sustained viability and continued compliance with all prudential norms and obligations, will be monitored under the program reviews.

10. BROU is committed to achieving financial viability by end-2004. In midDecember 2003, BROU's Executive Board declared its intention to move all nonperforming loans in Category 5 and most loans currently in Category 4 into a special workout vehicle (fiduciary trust). The main lines of the action plan are as follows:

- A first tranche, including all Category 5 loans above US\$100,000, has been legally removed from BROU's balance sheet by end-December 2003, and transferred to the fiduciary trust. The book value of these loans is estimated at US\$370 million.

- $\quad$ All Category 4 loans above US\$100,000 that fall into Category 5 during January-March 2004 will be transferred to the fiduciary trust by March 31, 2004 (a performance criterion). In addition, all Category 4 and 5 nonperforming loans above US\$50,000 will be transferred to the fiduciary trust by June 30, 2004 and all new and remaining Category 4 and 5 nonperforming loans, regardless of amount, will be transferred to the fiduciary trust by December 31, 2004 (performance criteria).

- $\quad$ As required under Uruguayan prudential norms, the value of all assets in the fiduciary trust will be reassessed within six months by an internationally reputable audit firm.

- $\quad$ The fiduciary trust, established in December 2003, will be administered by an entity owned by BROU. To allow for effective asset recovery, the manager of the trust will contract the specialized services of professionals experienced in dealing with nonperforming loans to implement the government's asset recovery strategy (an endMarch performance criterion).

- In return for the loans it receives, the entity in charge of administering the fiduciary trust will issue notes which will be fully backed by a government guarantee. These notes will be amortized over a four-year period under a schedule determined by loan recovery expectations, and pay interest. The government guarantee, provided upfront, will cover the entire book value of the loans to be transferred.

11. BROU will continue to build up liquidity for the repayment of reprogrammed deposits. The government will continue to use the resources of the Fund for the Stability of the Banking System (FSBS) as originally envisaged-to provide backing for sight and 
savings deposits at qualifying banks. The government is also taking steps to ensure that the claim of BROU on Banco Hipotecario del Uruguay (BHU), originating from the 2002 transfer of reprogrammed time deposits, is serviced on time. In December 2003, all arrears were cleared, and the timely service of this note (consistent with the government guarantee, if necessary), restructured in line with BHU's payment capacity, is proposed as a continuous performance criterion under the program.

12. Progress is being made in the resolution of the assets of liquidated banks. Nuevo Banco Comercial (NBC), the government-owned bank created in early-2003 with part of these assets, has proven quite successful at attracting new private sector deposits, and has been able to make significant progress in the restructuring of its NPL portfolio. As envisaged, NBC has fully exercised its option to return to the liquidation funds all loans that are not performing by December 31, 2003. Meanwhile, the government is completing the sale of the remaining assets of Banco de Crédito, which had been liquidated in February 2003. The government continues to intend to outsource the administration of the remaining assets of the other three liquidation funds. To that effect, several private entities have been prequalified to participate in a competitive bidding to administer these assets, with final selection scheduled for no later than end-February 2004 (a performance criterion).

13. The recommendations of the on-site Safeguards Assessment completed by the Fund in 2002 are being implemented. In particular, an external audit of the 2003 central bank accounts is under way, and the BCU has asked an external audit company for additional work on the FSBS audit completed last August. This supplemental audit, which will focus on use of FSBS funds by recipient banks, is to be completed by end-March 2004. In October 2003, Uruguay also ratified the International Convention for the Suppression of the Financing of Terrorism.

\section{Structural Reforms and Data Provision}

14. To foster the return to sustained economic growth, the government is deepening reforms aimed at encouraging investment, strengthening the role of the private sector, and furthering Uruguay's integration into the world economy. Toward these ends, we are implementing the following measures:

- The government will continue to promote a business climate that facilitates investment. Efforts to promote foreign direct investment will build on the successful award in August 2003 of the concession to operate the Montevideo airport. Negotiations on a bilateral investment treaty have been initiated with the United States. A two-year extension of fiscal incentives has been granted for investment projects that were delayed during the economic crisis in 2002.

- $\quad$ Recently approved legislation, providing a legal framework for trust funds, will help foster the development of new instruments for corporate financing, including in the export sector. Equity investments in NBC are currently being solicited, including from the IFC and other international investors. The government also plans to present 
legislation to congress aimed at improving the efficiency and coverage of the existing unemployment insurance scheme.

- $\quad$ A free trade agreement with Mexico has been signed, and further trade reform measures are being implemented, including reductions in tariffs on capital goods for equipment and telecommunications, information technology, and agricultural inputs from 6-9 percent to 2 percent, effective January 1, 2004 for a seven-year period. At the same time, the government will continue to phase out a number of specific import duties on textiles, foodstuffs, and chemical products.

- The government is promoting Uruguay's transformation into a regional distribution and logistics hub. Concessions have been awarded to the private sector to operate the Montevideo and Nueva Palmira ports, two new private ports are being developed, and a tender has been issued for the rehabilitation and maintenance of the public railroad network. In addition, more generous rules of origin that were recently approved by Mercosur will enhance activity in the sector of goods in transit.

15. The government will continue to work toward building consensus for adoption of tax and pension reforms during 2004, in advance of the 2005 budget. In late-June, the government submitted a revised tax reform proposal to congress, aimed at improving the efficiency of the tax system and strengthening tax collection through the elimination of several low yielding-taxes and the broadening of the VAT, excise, and corporate income tax bases. In 2003, congress approved the reform of the specialized pension fund for university professionals, and the government will continue to work actively toward securing congressional approval for the reform of the pension funds for the police, the military, and bank employees during 2004.

16. The process of subscription to the SDDS has been initiated, and data reporting and transparency will be improved. Monthly bank balance sheet data will continue to be published with a lag of no more than two months. Measures are also being taken to improve the timely provision and presentation of fiscal data for program monitoring purposes, including through improved coordination between data sources and the BCU and the allocation of more resources for data collection and analysis.

\section{FinanCing Assurances}

17. The program remains fully financed. Residual financing needs for the near term have been addressed to a large extent by the debt exchange in May. The continued implementation of structural reforms is expected to ensure a significant flow of IFI disbursements, projected to amount to US\$270 million in 2004, broadly in line with amortization. In addition, the government plan to use in 2004 part of a cushion built in 2003 with multilateral disbursements and the recent issuance of a US\$200 million three-year, inflation-indexed, bond in the international market. Any remaining financing needs for 2004, which appear manageable (around US\$200-300 million), are expected to be covered through placement of bills and bonds in the domestic and international markets. 
Table 1. Uruguay: Performance Criteria and Indicative Targets Under the 2004 Economic Program 1/

\begin{tabular}{rccc} 
Dec. 2003 & Mar. 31 & June $30 \quad$ Sept. 30 & Dec. 31 \\
\cline { 2 - 4 } Base & \multicolumn{4}{c}{ Targets }
\end{tabular}

\section{A. Quantitative performance criteria 2/}

1. Combined public sector primary balance (floor) $3 / 4 /$

2. General government noninterest expenditure (ceiling) 3/

3. Change in the net domestic assets of the BCU (ceiling) 3/

n millions of U.S. dollars)
4. Change in net international reserves of the BCU (floor) $3 / 5 /$
$-1,723$
$-30$
50
50
100
5. Nonfinancial public sector gross debt (ceiling) $4 / 6 /$
8,772
8,853
$8,864 \quad 9,004$
9,036

\section{B. Indicative targets}

1. Combined public sector overall balance (floor) 3/4/ $7 /$

(In millions of Uruguayan pesos)

2. Change in the monetary base (ceiling) $8 /$

$\begin{array}{rrrr}-5,171 & -7,848 & -12,567 & -12,007 \\ 550 & 800 & 1,000 & 2,200\end{array}$

Date

\section{Structural performance criteria}

Liquidated banks . Selection of winning bid for outsourcing of assets of

February 29, 2004

liquidated banks.

$\boldsymbol{B R O U}$. General manager of fiduciary trust to enter into contract for the specialized

March 31, 2004

services of professionals experienced in dealing with nonperforming loans.

March 31, 2004

BROU. Completion of the transfer to the fiduciary trust of all Category 4 nonperforming

loans above US $\$ 100,000$ (more than 150 days overdue) that have become Category 5

(more than 240 days overdue).

BROU. Completion of the transfer to the fiduciary trust of all Category 4 and 5

June 30, 2004

loans above US $\$ 50,000$.

BROU. Completion of the transfer to the fiduciary trust of all new and remaining

Category 4 and 5 loans.

December 31, 2004

$\boldsymbol{B H U}$. Government to ensure timely service of BHU note to BROU

Continuous

1/ As defined in the Technical Memorandum of Understanding (TMU).

2/ Indicative targets for end-September and end-December 2004.

3/ Cumulative changes from end-December 2003.

4/ Adjusted upward/downward for changes in social security contributions, as defined in the TMU.

5/ Adjusted upward/downward for changes in program disbursements from the World Bank and IDB, as defined in the TMU.

6/ Stock of debt at the end of the period; all maturities. The 2003 base includes all loans guaranteed by the government.

7/ Adjusted upward/downward for changes in interest payments, as defined in the TMU.

8/ Cumulative change from December 2003 average. 
Table 2. Uruguay: Structural Conditionality Under 2004 Economic Program

\section{A. Prior actions}

BROU. Selection of general manager of the fiduciary trust

BROU. Issuance of unconditioned government guarantee on the performance of the notes to be issued by the fiduciary trust in exchange for loans transferred from BROU.

Liquidated banks. Call for bids for outsourcing of assets of liquidated banks

\section{B. Structural benchmarks}

FSBS. Completion of supplementary external audit

BROU. Completion of external audit by an internationally reputable firm of assets transferred to the fiduciary trust

Pension reform. Approval by Congress of the reform of pension funds for the police and the military

BCU. Completion of external audit of 2003 accounts

Tax administration. Establishment of a Large Taxpayer Unit at the DGI

Pension reform. Approval by Congress of the reform of pension funds for bank employees 


\section{TeChNiCAl Memorandum of Understanding}

This memorandum presents the definitions of the variables included in the quantitative performance criteria and quantitative benchmarks annexed to the Memorandum of Economic and Financial Policies.

1. Cumulative primary balance of the combined public sector. The combined public sector comprises the central administration (including as defined in "Article 220" of the Constitution, Salto Grande, and the funds managed directly in the ministries (Fondos de Libre Disponibilidad), the social security system (Banco de Previsión Social, Caja Militar, and Caja Policial), the local governments (Intendencias), the public enterprises (ANCAP, ANTEL, UTE, OSE, AFE, ANP, INC, and ANCO), and the quasifiscal balance of the Central Bank (BCU). The public sector primary balance, excluding valuation adjustments, will be calculated as the overall balance measured from below the line minus interest payments measured from above the line.

- $\quad$ The below the line overall balance will be measured on the basis of information provided by the BCU on: (i) the change in the nonfinancial public sector debt (defined below), including all short term debt, in foreign currency and pesos; (ii) change in net bank credit to the nonfinancial public sector in foreign currency and pesos; (iii) other nonbank financing including privatization; and (iv) the quasifiscal balance of the BCU (defined below).

- $\quad$ The floor on the primary balance of the combined public sector will be adjusted downward (upward) by the amount by which the actual social security contributions to the private pension system exceeds (falls short of) the projected amounts in the program, specified in Schedule A.

\begin{tabular}{|lrrrrr|}
\hline \multicolumn{7}{|c|}{ Schedule A } \\
(in millions of Uruguayan pesos; cumulative basis) & & \\
\hline & Mar-04 & Jun-04 & Sep-04 & Dec-04 \\
\hline Projected social security contributions & 824 & 1,573 & 2,416 & 3,191 \\
\hline
\end{tabular}

2. Cumulative balance of the combined public sector (indicative target). The combined public sector balance is calculated as the sum of the primary balance of the combined public sector described in 1 and interest payments. Interest payments are defined to exclude commissions and fees. The floor on the balance of the combined public sector will be adjusted downward (upward) by the amount that the interest payments exceed (fall short of) the projected amounts in the program, specified in Schedule B for end-March, end-June, and end-September, and end-December. 


\begin{tabular}{|lrrrr|}
\hline \multicolumn{6}{|c|}{ Schedule B } \\
(in millions of Uruguayan pesos; cumulative basis) & \\
\hline & Mar-04 & Jun-04 & Sep-04 & Dec-04 \\
\hline Projected interest payments & 7,068 & 11,454 & 19,340 & 23,591 \\
\hline
\end{tabular}

3. The quasifiscal balance of the BCU is defined as interest earnings on gross international reserves, as defined below, and other earnings including those on other foreign and domestic assets minus operating expenses, commissions paid, and interest paid on domestic and foreign debt administered by the BCU.

4. Cumulative ceiling on general government expenditure applies to total (current and capital) noninterest expenditure of the central administration (includes Fondos de Libre Disponibilidad but excludes transfers to the social security system, automatic transfers to the private pension funds (AFAPs), and earmarked revenue) and the social security system (BPS).

5. Cumulative changes in net domestic assets (NDA) of the BCU is defined as the difference between end-of-period monetary base and net international reserves (NIR) of the BCU as defined in 6 and 7 below. The flow of NIR will be valued at the accounting exchange rate of Ur\$31 pesos per US\$1. The limit on the change in the NDA will be adjusted by the difference between actual program loan disbursements by the World Bank and IDB and scheduled loan disbursements as reflected in Schedule C:

- $\quad$ The NDA ceiling at end-March, end-June, end-September, and end-December will be adjusted upward in the event of shortfalls compared with projected program loan disbursements, up to a limit of US\$50 million.

- $\quad$ The NDA ceiling will be adjusted downward in the event of excesses over projected program loan disbursements by their full amount.

\begin{tabular}{|lrrrr|}
\hline \multicolumn{4}{c|}{$\begin{array}{c}\text { Schedule C } \\
\text { (in millions of U.S. dollars; cumulative basis) }\end{array}$} & \\
\hline & Mar-04 & Jun-04 & Sep-04 & Dec-04 \\
\hline Total program loan disbursements & 110 & 110 & 195 & 195 \\
World Bank & 50 & 50 & 100 & 100 \\
IDB & 60 & 60 & 95 & 95 \\
of which: Multisectoral Loan & 0 & 0 & 35 & 35 \\
\hline
\end{tabular}

6. Monetary base (indicative target) is defined as the sum of (i) currency issue;

(ii) nonremunerated and remunerated peso sight deposits of BROU, BHU, private banks, and other institutions defined below at the BCU; and (iii) call deposits of BROU, BHU, private banks, and other institutions at the BCU. Other institutions include pension funds (AFAPs), 
local governments, public enterprises, trust funds of the liquidated banks (FRPB), investment funds, offshore institutions (IFEs), insurance companies, exchange houses, stock brokers, and the nonfinancial private sector. The monetary base excludes central government deposits held at BROU subject to a 100 percent reserve requirement. The indicative target is defined as the cumulative change calculated using the monthly averages relative to the base month average.

\section{Cumulative changes in net international reserves (NIR) of the BCU. NIR is}

defined as the difference between the gross international reserves and BCU reserve liabilities. Gross international reserves include all foreign exchange assets that are in the direct effective control of the BCU and are readily available for such purposes of the BCU as intervention or direct financing of payment imbalances. Such assets may be in any of the following forms, provided that they meet the test of effective control and ready availability for use: currency, bank deposits in nonresident institutions and government securities and other bonds and notes issued by nonresidents (with a rating not below " $\mathrm{A}$ " in the classification of Fitch and IBCA and Standard and Poor's or "A2" in the classification of Moody's). In addition, holdings of SDRs or of monetary gold would be included under gross international reserves (provided they meet the test of effective control and ready availability of use) as would the reserve position in the IMF.

- $\quad$ Excluded from gross international reserves are all foreign currency claims arising from off-balance sheet transactions (such as derivatives instruments), claims on residents, capital subscriptions to international financial institutions, any assets in nonconvertible currencies, claims on any nonresident Uruguay-owned institutions, or any amounts (in all components of assets, including gold) that have been pledged in a direct or contingent way.

- $\quad$ Also excluded from gross international reserves are foreign exchange assets in the escrow account at the BCU created to provide backing to sight and savings deposits at the public banks and the closed domestic banks (the escrow account at the BCU). Funds not used to support banks will be invested in highly liquid and secure international assets to be reported daily to the IMF and will be subject to periodic special audits.

- $\quad$ BCU reserve liabilities include all foreign currency-denominated liabilities of the BCU with original maturity of one year or less to residents and nonresidents, all certificates of deposit used to constitute reserve requirements against bank deposits, the use of Fund resources, any net position on foreign exchange derivatives with either residents or nonresidents undertaken directly by the BCU or by other financial institutions on behalf of the BCU.

- $\quad$ For the purpose of the NIR calculation, (i) the gold holdings of the BCU will be valued at the accounting rate of US\$42 per troy ounce; (ii) liabilities to the IMF will be valued at the rate of US\$1.395 per SDR; (iii) gains or losses from gold swaps and other operations will be excluded; and (iv) non-U.S. dollar denominated foreign assets and liabilities will be converted into U.S. dollars at the market exchange rates of the respective currencies as of December 31, 2003. 
8. The NIR floor will be adjusted by the difference between actual program loan disbursements by the World Bank and IDB, and scheduled loan disbursements by the World Bank and IDB as reflected in Schedule C, in the following manner:

- $\quad$ The NIR floor at end-June, end-September, and end-December will be adjusted downward in the event of shortfalls compared with projected program loan disbursements, up to a limit of US\$50 million.

- $\quad$ The NIR floor will be adjusted upward in the event of excesses over projected program loan disbursements by their full amount.

9. The nonfinancial public sector gross debt refers to the outstanding stock of gross debt in domestic and foreign currency owed or guaranteed by the nonfinancial public sector, excluding the BCU. ${ }^{1}$ Debt in the form of leases will be calculated as the present value (at the inception of the lease) of all lease payments expected to be made during the period of the agreement excluding those payments that cover the operation, repair or maintenance of the property. ${ }^{2}$ The nonfinancial public sector debt ceiling will exclude the government guaranteed BHU note (estimated at US\$610 million at end-December 2003) and the government guarantee covering notes issued by the fiduciary trust associated with the transfer of BROU's NPLs (estimated at US\$370 million at end-December 2003). It will include debt issued by the Megaconcesión that has a guarantee of the government.

\section{The overall nonfinancial public sector debt ceiling will be adjusted upward}

(downward) by (i) the upward (downward) revisions made to the actual nonfinancial public sector gross debt stock at end-2003; (ii) the difference between the actual and projected amount of social security contributions that are transferred to private pension funds according to Schedule A, i.e., the debt ceiling will be adjusted upward (downward) by the amount that social security contributions exceed (fall short of) those specified in Schedule A; (iii) the difference between the actual and projected interest payments, specified in Schedule B for end-March, end-June, and end-September, and end-December, i.e. the debt ceiling would be adjusted upward (downward) by the amount that interest payments exceed (fall short of)

${ }^{1}$ The term "debt" has the meaning set forth in point No. 9 of the Fund's Guidelines on Performance Criteria with Respect to Foreign Debt (Decision No. 6230-(79/140, August 3, 1979), as amended).

${ }^{2}$ The suppliers' contracts of ANTEL with equipment providers Ericsson and NEC, which predate the Fund's consideration of lease contracts for programming purposes, are expensed under goods and services as rental outlays and, therefore, excluded from the definition of nonfinancial public sector gross debt for program purposes. 
those specified in Schedule B; (iv) the difference between actual and scheduled program disbursements by the World Bank and IDB as reflected in schedule $\mathrm{C}$ above, i.e. the debt ceiling will be adjusted upward (downward) by the amount that program loan disbursements exceed (fall short of) those in Schedule C, and any downward adjustment will be limited to US\$50 million; (v) the amount of the government guarantee on the BHU note that is called in 2004, excluding the clearance of existing arrears of BHU to BROU, i.e., the debt ceiling will be adjusted upward by the amount of new debt issued by the government to cover its guarantee (principal plus interest) on the BHU note; and (vi) the amount of the government guarantee on the transfer of BROU's NPLs to the fiduciary trust that is called in 2004, i.e., the debt ceiling will be adjusted upward by the amount of new debt issued by the government to cover its guarantee on the schedule of principal and interest payments owed by the trust to BROU; and (vii) the debt ceiling will be adjusted upward to reflect overperformance with respect to the targets on the BCU's net international reserves up to a limit of US\$250 million.

\section{The data for assessing observance of the quantitative performance criterion on} net international reserves will be provided by the BCU no later than one week after each test date. The data for the assessment of all other quantitative performance criteria and indicative targets will be provided by the $\mathrm{BCU}$ no later than two months after each test date. 


\section{BROU: FinanCial Condition ANd Proposed RestruCturing}

\section{Financial condition}

1. The state bank BROU accounts for a substantial part of the Uruguayan banking system. The bank holds about 50 percent of deposits and 44 percent of all loans. As a result, its financial condition has significant implications for the soundness of the banking sector and the public's confidence. In addition to its role as a commercial bank, BROU serves as the fiscal agent for the government and is a cornerstone of the payment system.

2. By any measure of bank soundness, BROU's financial condition is poor. At endSeptember 2003, BROU suffered operating losses, had a nonperforming asset to total asset ratio of 33 percent, had capital barely above adequacy requirements, and faced potential liquidity problems. BROU has stock problems on both sides of the balance sheet, which are compounded by serious operating inefficiencies.

3. BROU has an excessive volume of NPLs and other nonperforming assets. Its lending to the private sector has been severely impacted by the economic downturn, the banking crisis and poor credit policies, resulting in an NPL ratio for its private sector loans of about 60 percent.

4. The second tranche of reprogrammed deposits will fall due during the second half of 2004. ${ }^{3}$ Although BROU built up liquidity during 2003, it would not suffice to cover all the deposits falling due during August 2004-July 2005. Furthermore, BROU will need to build up additional liquidity to meet the deposits falling due starting August 2005. In addition to the liquidity concerns, these reprogrammed deposits currently carry an interest rate of 6 percent, well above market rates and a significant drag on earnings.

5. BROU suffers from high operating costs that are due to excess personnel and branches. The bank estimates that the return on total assets for 2003 was negative by $1 \frac{1}{2}$ percent. The bank barely meets its capital adequacy requirements. Its year-end estimate of capital to total assets only reaches 4.4 percent, leaving little room for a resumption of lending.

\section{Restructuring plan}

6. The authorities have developed a restructuring plan to address the balance sheet problems of BROU and assure its viability. The plan addresses the poor quality of assets,

\footnotetext{
${ }^{3}$ Assuming timely servicing of the BHU note, projections indicate that BROU would have sufficient liquidity to cover about two-thirds of these deposits falling due.
} 
the high costs and liquidity issues related to the reprogrammed deposits, and deficiencies in credit controls and monitoring. The plan also refocuses the business of the bank toward peso loans and deposits and seeks to reduce operating expenses.

\section{The key elements of the restructuring plan are:}

An asset management company has been established through the creation of a fiduciary trust, which although owned formally by BROU, will operate independently. The trust will issue notes to purchase NPLs from BROU at their net book value. It will operate for five years and will be required to recover the NPLs within four years to redeem the notes.

- All nonperforming Category 4 and 5 loans will be removed from BROU's balance sheet and replaced by an interest-earning note issued by the fiduciary trust and guaranteed by the government. This will help clean up the balance sheet and eliminate the negative impact on earnings stemming from the transferred assets.

- $\quad$ The government has cleared the arrears on the BHU note and is committed to keep this note current. This will help BROU meet its upcoming obligations on the reprogrammed deposits and avoid the need for BROU to set aside provisions for the BHU note.

- The interest rate on reprogrammed deposits will be reduced, and a program will be implemented to reduce noninterest expenses.

- Improved credit review and control procedures will be introduced to reduce the rate of nonperformance on its loans.

- $\quad$ BROU will focus new lending and deposit activities mainly in the peso market. Dollar-denominated loans will only be extended to clients with dollar earnings. 


\section{Debt Sustainability Analysis}

\section{Background}

1. Even after the comprehensive May 2003 debt exchange, Uruguay's debt situation remains a source of vulnerability. At end-2003, Uruguay's debt-to-GDP ratio was close to 100 percent of GDP, more than double its level at end-2001. This sharp increase reflected the large depreciation of the currency following the abandonment of the exchange rate peg in mid-2002, large disbursements from multilateral institutions in support to the banking system after the banking crisis, and financing associated with fiscal deficits.

2. The 2002 financial crisis as well as the debt exchange have led to important shifts in the composition of Uruguay's debt. The financial support package provided by multilateral institutions significantly increased their share in Uruguay's public debt stock. The successful debt exchange of May 2003 helped reduce the financing needs of the nonfinancial public sector and improve the debt-service profile over the medium term. During the first half of 2003, however, Uruguay's limited access to international capital markets forced the government to increase its stock of short-term debt to finance its fiscal deficit, thus increasing vulnerabilities related to the public-debt maturity structure.

3. During the second half of 2003, the improvement in Uruguay's overall macroeconomic situation, together with the success of the debt exchange and the authorities' commitment to a tight fiscal position, have helped improve confidence in international markets. Spreads of Uruguayan bonds fell from a high of nearly 2,000 basis points in mid2002 to around 600 basis points in early 2004. In late 2003, Uruguay successfully floated a US\$200 million inflation-indexed, peso-denominated bond in the international market.

\section{Cost of bank restructuring}

4. The revised debt sustainability analysis (DSA) includes revised macroeconomic projections and assumptions regarding the cost of restructuring the public banks. The Uruguayan government is facing large contingent liabilities related to the cost of restructuring these banks, estimated at US\$1.3 billion (about 10 percent of GDP, including interest). ${ }^{4}$ This debt reflects the government's guarantees on: (i) a US\$610 million BHU note to BROU; and (ii) an estimated US\$400-570 million of BROU's NPLs that are to be transferred to a fiduciary trust. The alternative set of projections assumes that these guarantees will be progressively called (mainly during 2005-09) over the medium term.

\footnotetext{
${ }^{4}$ The estimated cost of US\$1.3 billion reflects principal and interest payments associated with the government guarantees on the BHU note and BROU's NPLs.
} 


\section{Medium-term assumptions}

5. The medium term scenario is based on a steady recovery of real GDP and a moderate recovery of the peso against the U.S. dollar in real terms:

- $\quad$ Economic growth is projected to recover to about 4-5 percent a year during 2004-06, and to average $2 \frac{1}{2}-3$ percent a year subsequently.

- $\quad$ Over the medium term, the peso is projected to recover somewhat from its sharp depreciation in real terms against the U.S. dollar (26.8 percent in 2002 and 14 percent in 2003 on average), to about 75 percent of its 2001 level.

- $\quad$ Average interest rate spreads are projected to decline from 1,400 basis points in 2002 to 500 basis points over the medium term.

6. The medium term scenario is based on fiscal consolidation and improvement in the external current account:

- $\quad$ The primary surplus of the nonfinancial public sector is projected to rise from close to 3 percent in 2003 to 4 percent of GDP by 2007, and to remain at that level in subsequent years. Over the medium term, the primary surplus would average 3.4 percent of GDP, representing a significant shift from a deficit of 0.2 percent of GDP on average over the past decade.

- $\quad$ Mirroring this adjustment, the non-interest external current account surplus is projected to improve from 0.2 percent of GDP on average over the past decade to roughly 4 percent of GDP on average over the medium term.

\section{Medium-term outlook and DSA}

7. The staff has constructed two (In percent of GDP)

scenarios, taking into account the possible impact of bank restructuring (Figure 1). The first scenario assumes that the government guarantees are called in full, and this scenario therefore includes the entire gross bank restructuring costs. The second scenario assumes that the BHU and the fiduciary trust generate enough internal resources to avoid recourse to the government guarantees. In Attached Tables 1 and 2, the costs of bank restructuring for the fiscal accounts are included in the line

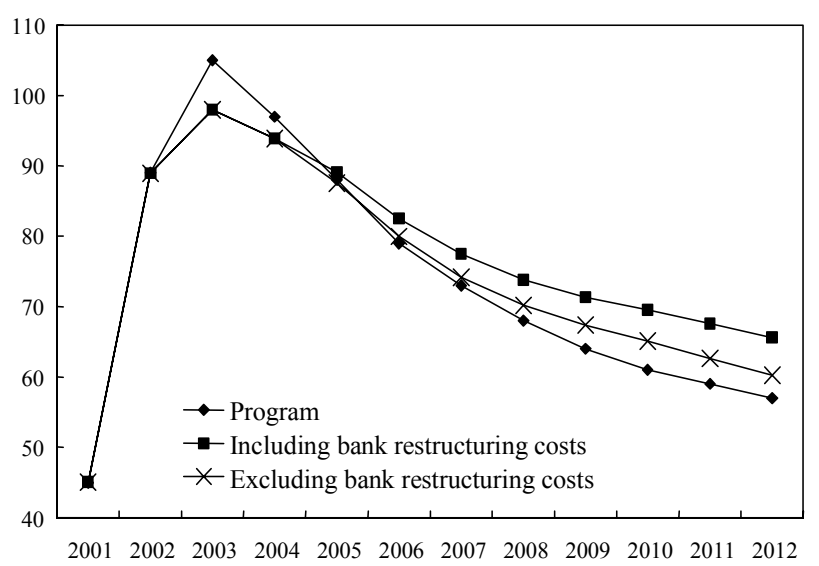

Source: Uruguayan authorities and Fund staff estimates. "augmented public sector deficit" as expenditure, while bank asset recovery is treated as revenue. 
8. The projections show that, if the government guarantees were called in full, the debt-to-GDP ratio would reach 83 percent by 2006, 74 percent by 2008, and 66 percent by 2012 (Table 1 and Attached Table 1). This 2012 figure compares with 60 percent in the scenario where the restructuring costs are excluded (Attached Table 2), and 57 percent in the previous staff report, in which the cost of bank restructuring had not been factored in (Country Report No. 03/247). The scenarios assume continued access to IFI financing over the medium term, and a gradual return to international capital markets. The projections do not include any additional Fund support beyond the current arrangement. ${ }^{5}$ The resulting financing gaps - emerging in 2005-will require additional market and IFI financing, possibly including from Fund.

Table 1. Uruguay: Medium-term Nonfinancial Public Sector Debt Dynamics (Includes costs of bank restructuring)

Nonfinancial public sector debt (percent of GDP)

\begin{tabular}{rrrrrr}
2003 & 2004 & 2005 & 2006 & 2007 & 2008 \\
\hline 98.0 & 93.9 & 89.1 & 82.5 & 77.5 & 73.8
\end{tabular}

Key macroeconomic assumptions:

Real GDP growth (in percent) GDP deflator (change in percent) Average nominal interest rate (in percent) Primary balance (percent of GDP) 1/

\begin{tabular}{rrrrrr}
1.0 & 5.0 & 4.0 & 4.0 & 3.0 & 3.0 \\
20.7 & 8.0 & 7.0 & 6.9 & 6.5 & 5.4 \\
7.9 & 6.4 & 5.8 & 6.1 & 6.7 & 7.3 \\
2.9 & 3.4 & 3.5 & 3.5 & 4.0 & 4.0 \\
\hline
\end{tabular}

Sources: Uruguayan authorities and Fund staff estimates.

1/ Nonfinancial public sector.

9. Even with the tight fiscal conditions, the debt stock will remain high over the medium term. Thus, it will be critical to avoid increasing the debt stock through a combination of:

(i) achieving and, if possible, exceeding the primary surplus targets in the program;

(ii) comprehensive restructuring of BHU to ensure that it can service its debts to BROU on time; and (iii) strong asset recovery by the financial trust administering BROU's NPLs.

${ }^{5}$ The projections presented in Country Report No. 03/247 had explicitly assumed Fund financial support to Uruguay — on a gradually declining scale — in years following the end of the current arrangement, subject to the normal applicable requirements for Fund support, including a satisfactory policy stance (Paragraph 22 of Country Report No. 03/247, Supplement 1). 
Figure 2. Uruguay: Projected Debt Dynamics, 2003-08 (In percent of GDP)

10. On the external side, the debt dynamics improve somewhat more rapidly, mainly due to the fact that the costs of the bank restructuring only affect the public debt. The presence of small current account surpluses, along with assumed moderate appreciation of the peso over the medium term, result in a decline of the external debt-to-GDP ratio (including private sector debt) from 96 percent in 2003 to 60 percent by 2008 (Figure 2).

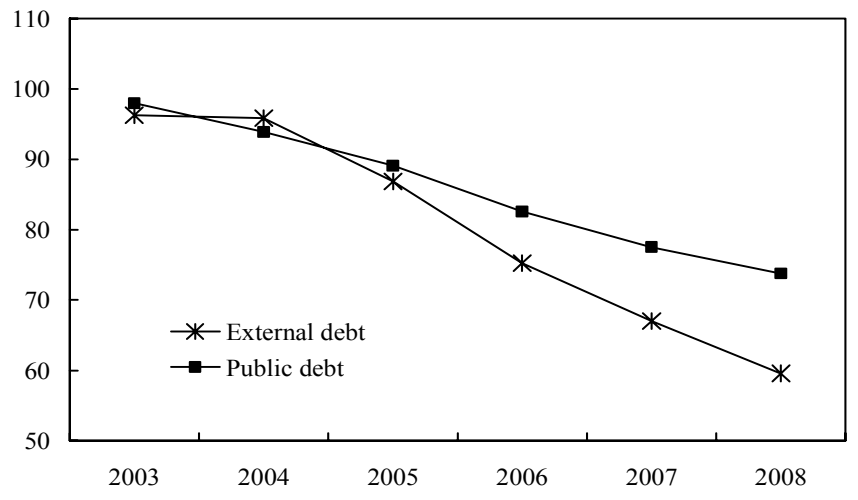

Sources: Uruguayan authorities and Fund staff estimates.

Table 2. Uruguay: Medium-term External Debt Dynamics

\begin{tabular}{|c|c|c|c|c|c|c|}
\hline & 2003 & 2004 & 2005 & 2006 & 2007 & 2008 \\
\hline External debt (percent of GDP) & 96.2 & 95.8 & 86.8 & 75.2 & 67.0 & 59.6 \\
\hline \multicolumn{7}{|l|}{ Key macroeconomic assumptions: } \\
\hline Real GDP growth (in percent) & 1.0 & 5.0 & 4.0 & 4.0 & 3.0 & 3.0 \\
\hline GDP deflator in U.S. dollars (change in percent) & -7.5 & 1.8 & 4.8 & 6.5 & 5.2 & 3.4 \\
\hline Non-interest current account balance (percent of GDP) & 4.5 & 4.6 & 4.8 & 4.2 & 3.7 & 3.2 \\
\hline
\end{tabular}

Sources: Uruguayan authorities and Fund staff estimates.

\section{Sensitivity analysis}

11. As experienced in the 2002 financial crisis, Uruguay's debt stock is highly exposed to changes in macroeconomic variables. In case of a serious shock, it is likely that most variables would deteriorate at the same time, potentially leading to a prolonged period of sluggish growth and a high interest rate environment. Alternative scenarios examine the implications of holding key variables at their historical averages, ${ }^{6}$ as well shocks to these key variables.

- $\quad$ An alternative scenario for public debt which keeps the primary surplus at 2.5 percent of GDP — slightly lower than that in 2003 — would lead to only a small reduction in the public debt-to-GDP ratio from 98 percent in 2003 to 90 percent in 2008 (Figure 3).

${ }^{6}$ Historical averages do not include the year 2002 (the crisis year). 
An alternative scenario for external debt, with key variables Figure 3. Uruguay: Alternative Scenarios, 2003-08 (In percent of GDP) at their historical averages, results in a sharply worsened path for the external debt-to-GDP ratio, reaching 102 percent by 2008 (Figure 3).

\section{Most sensitivity tests for public} debt indicate that shocks to key variables would lead to increases in the public debt-to-GDP ratio over the next 2-3 years, followed by renewed declines thereafter (Figure

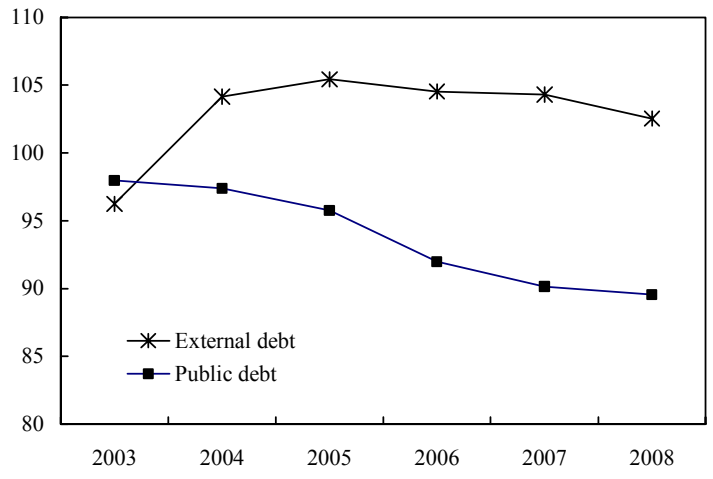

Source: Uruguayan authorities and Fund staff estimates.

4). However, a two standard deviation shock to GDP growth ${ }^{7}$ would lead to a sharp increase in this ratio, to 126 percent in 2008. The impact of this shock is particularly severe for Uruguay's debt profile for two reasons: (i) the V-shaped recovery assumes relatively strong GDP growth in 2004 and 2005, which means that the shock eliminates the years with the best growth performance; and (ii) the primary balance also deteriorates in this scenario since expenditure is kept constant in peso terms, thus worsening in percent of GDP, and revenue is kept constant in percent of GDP. Keeping the primary surplus unchanged in this scenario would result in a somewhat lower path, with the debt-toGDP ratio reaching 112 percent in 2005, before falling to 96 percent in 2008 .

- The sensitivity tests for external debt also indicate significant vulnerabilities, although they do not show explosive paths. The external debt-to-GDP ratio would reach 85 in 2008 percent in the case of a shock to the U.S. dollar GDP deflator, and to 95 percent in 2008 if a combined shock were to occur (Figure 4).

\section{Some of the stress tests appear inappropriately pessimistic in light of the fact} that Uruguay is just emerging from a crisis. In 2002, Uruguay already experienced severe shocks, with a drop in real GDP of close to 11 percent, a sharp depreciation of the Uruguayan peso, and significant increases in nominal interest rates on the public debt. Thus, a repeat of such major shocks would appear rather unlikely, particularly for the exchange rate and U.S. dollar deflator shocks. Overall, the implementation of strong policies should reduce the country's vulnerability over the medium term.

\footnotetext{
${ }^{7}$ GDP at its historical average minus two standard deviations in 2004 and 2005 and the primary balance worsens over time as a result of the lower GDP.
} 

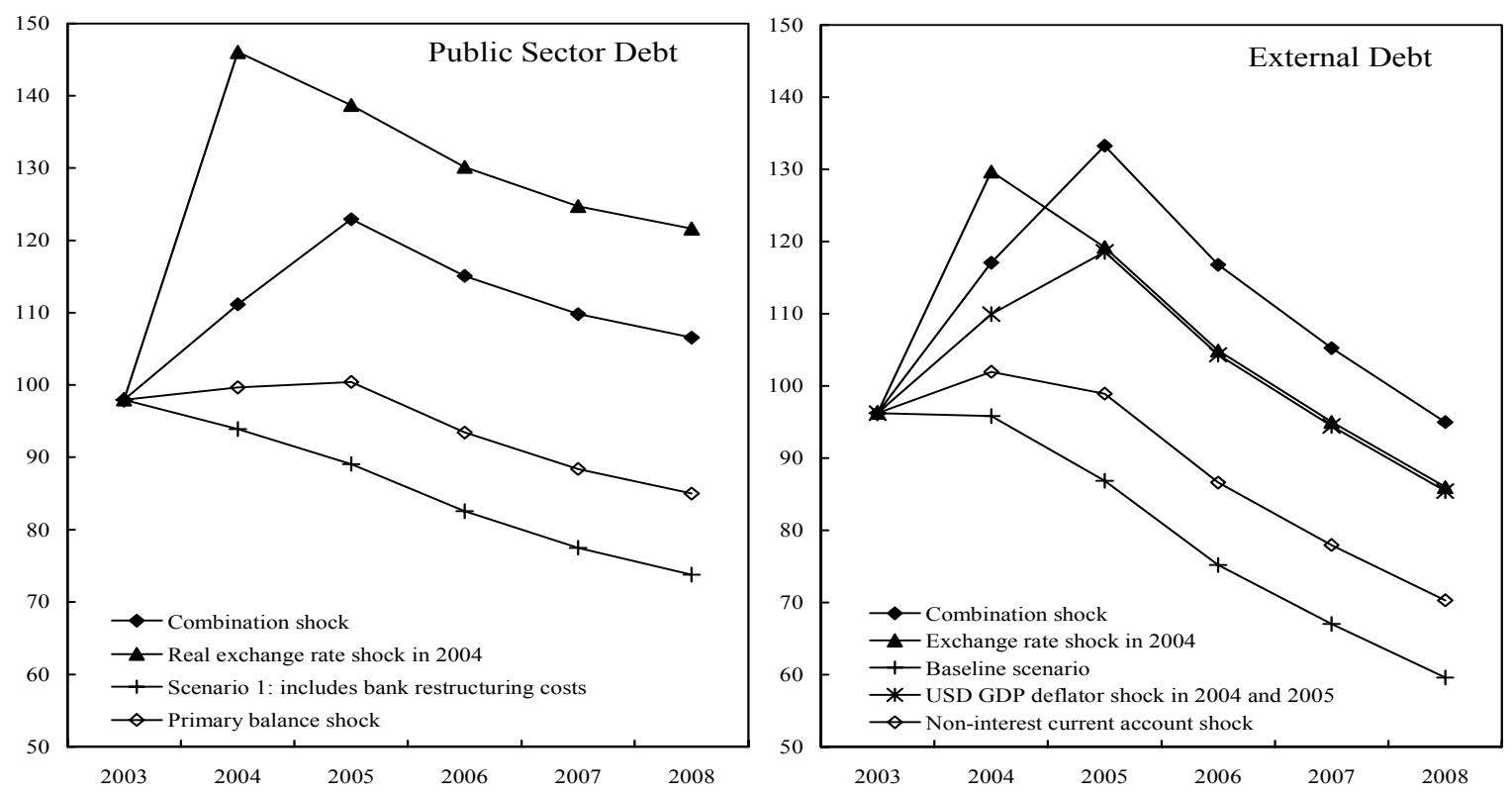

Sources: Uruguayan authorities and Fund staff estimates.

\section{Financing needs}

13. Uruguay will continue to face large financing needs in the medium term. As the return to international markets is expected to be gradual, Uruguay will continue to have to rely on short-term and multilateral financing, including from the Fund, over the medium term. Although the financing gaps projected in the central scenario are large, they should be manageable with continued support from the international community.

\section{Concluding remarks}

14. The Uruguayan economy faced a severe shock in 2002 which more than doubled its public and external debt-to-GDP ratios. As a result, strong policy performance over the medium term is needed to ensure that these ratios decline gradually to sustainable levels. To this effect, the Uruguayan authorities have committed to pursuing a primary surplus of about 3.5 percent of GDP, on average, over the medium term. This is in addition to the achievement of a nonfinancial public sector primary surplus of 2.9 percent of GDP in 2003, broadly in line with the program. Economic growth has resumed and is expected to be strong in 2004, but laying the foundation for solid growth over the medium term will require the continued pursuit of structural reforms, particularly in the banking area. On this basis, Uruguay's debt dynamics would improve over the medium term although the projections are sensitive to renewed shocks, especially to growth, the exchange rate, and the fiscal accounts. 


\begin{tabular}{|c|c|c|c|c|c|c|c|c|c|c|c|c|}
\hline & \multirow[b]{2}{*}{2001} & \multicolumn{11}{|c|}{ Projections } \\
\hline & & 2002 & 2003 & 2004 & 2005 & 2006 & 2007 & 2008 & 2009 & 2010 & 2011 & 2012 \\
\hline \multicolumn{13}{|c|}{ A Assumptions } \\
\hline Real GDP growth (percent) & -3.4 & -10.8 & 1.0 & 5.0 & 4.0 & 4.0 & 3.0 & 3.0 & 3.0 & 2.5 & 2.5 & 2.5 \\
\hline Interest rate spread (bps) & 284 & 1400 & 900 & 700 & 700 & 600 & 600 & 500 & 500 & 500 & 500 & 500 \\
\hline Real U.S. dollar exchange rate (change in percent) & -13.8 & -26.8 & -14.0 & 1.6 & 6.3 & 4.4 & 4.2 & 1.4 & 0.0 & 0.0 & 0.0 & 0.0 \\
\hline Primary balance: Consolidated public sector & -1.2 & 0.4 & 2.8 & 3.2 & 3.3 & 3.3 & 3.8 & 3.8 & 3.8 & 3.8 & 3.8 & 3.8 \\
\hline Non-financial public sector & -1.0 & 0.5 & 2.9 & 3.4 & 3.5 & 3.5 & 4.0 & 4.0 & 4.0 & 4.0 & 4.0 & 4.0 \\
\hline $\mathrm{BCU}$ & -0.2 & -0.1 & -0.2 & -0.2 & -0.2 & -0.2 & -0.2 & -0.2 & -0.2 & -0.2 & -0.2 & -0.2 \\
\hline Overall Balance: Consolidated public sector & -4.2 & -4.5 & -3.4 & -3.3 & -2.2 & -2.1 & -1.7 & -1.8 & -1.7 & -1.7 & -1.4 & -1.4 \\
\hline Non-financial public sector & -3.7 & -4.2 & -2.8 & -2.1 & -1.4 & -1.3 & -0.9 & -1.0 & -0.9 & -0.9 & -0.6 & -0.6 \\
\hline $\mathrm{BCU}$ & -0.3 & -0.3 & -0.6 & -1.2 & -0.8 & -0.8 & -0.8 & -0.8 & -0.8 & -0.8 & -0.8 & -0.8 \\
\hline \multicolumn{13}{|c|}{ B. Debt Dynamics (in percent of GDP) } \\
\hline Gross non-financial public sector debt & 45 & 89 & 98 & 94 & 89 & 83 & 78 & 74 & 71 & 70 & 68 & 66 \\
\hline \multicolumn{13}{|c|}{ C. Cash Flow (in millions of U.S. dollars) } \\
\hline Gross borrowing needs & 1200 & 3278 & 1063 & 763 & 1172 & 1694 & 1412 & 947 & 857 & 891 & 1500 & 1174 \\
\hline Augmented public sector deficit & 700 & 2510 & 315 & 244 & 381 & 312 & 222 & 187 & 220 & 234 & 190 & 185 \\
\hline Public sector deficit & 700 & 512 & 315 & 254 & 181 & 195 & 142 & 165 & 165 & 161 & 119 & 118 \\
\hline Bank assistance 1/ & 0 & 1998 & 171 & 170 & 200 & 167 & 129 & 52 & 56 & 74 & 71 & 67 \\
\hline Bank asset recovery $2 /$ & 0 & 0 & -171 & -180 & 0 & -50 & -50 & -30 & 0 & 0 & 0 & 0 \\
\hline Amortization & 500 & 768 & 748 & 519 & 791 & 1381 & 1190 & 760 & 636 & 657 & 1310 & 989 \\
\hline Bonds, long-term & 403 & 349 & 257 & 25 & 123 & 108 & 105 & 238 & 213 & 362 & 987 & 671 \\
\hline Commercial bank loans & 0 & 214 & 217 & 38 & 31 & 12 & 8 & 4 & 4 & 9 & 16 & 7 \\
\hline IDB/WB and other official debt & 97 & 205 & 234 & 265 & 364 & 441 & 404 & 212 & 241 & 273 & 307 & 311 \\
\hline IMF & 0 & 0 & 40 & 192 & 273 & 820 & 674 & 306 & 179 & 13 & 0 & 0 \\
\hline Gross Financing & 1199 & 3278 & 1062 & 763 & 914 & 947 & 871 & 503 & 467 & 507 & 530 & 529 \\
\hline Short-term bonds (net) & -32 & 383 & 244 & 25 & 100 & 100 & 100 & 50 & 0 & 0 & 0 & 0 \\
\hline Long-term bonds & 1292 & 143 & 405 & 246 & 250 & 250 & 250 & 200 & 200 & 200 & 200 & 200 \\
\hline Commercial bank loans & 85 & 0 & -288 & 200 & 0 & 0 & 0 & 0 & 0 & 0 & 0 & 0 \\
\hline IDB/WB and other official debt & 198 & 789 & 467 & 292 & 364 & 430 & 392 & 201 & 211 & 234 & 260 & 261 \\
\hline IMF & 0 & 1302 & 0 & 0 & 0 & 0 & 0 & 0 & 0 & 0 & 0 & 0 \\
\hline Central bank credit (net) & 7 & 665 & 297 & 0 & 0 & 0 & 0 & 0 & 0 & 0 & 0 & 0 \\
\hline Other inflows (net) 3/ & -351 & -3 & -63 & 0 & 200 & 167 & 129 & 52 & 56 & 74 & 71 & 67 \\
\hline Residual financing needs & $\mathbf{0}$ & $\mathbf{0}$ & $\mathbf{0}$ & $\mathbf{0}$ & 258 & 747 & 541 & 444 & 390 & 384 & 970 & 645 \\
\hline \multicolumn{13}{|c|}{ D. Other Indicators } \\
\hline Total debt service (in percent of GDP) & 5.5 & 10.7 & 12.3 & 9.8 & 10.9 & 14.3 & 12.4 & 9.5 & 8.5 & 8.4 & 11.4 & 9.5 \\
\hline Residual financing needs (in percent of GDP) & 0.0 & 0.0 & 0.0 & 0.0 & 2.0 & 5.1 & 3.4 & 2.6 & 2.2 & 2.1 & 5.0 & 3.2 \\
\hline Average interest rate (in percent) & 6.3 & 4.9 & 5.8 & 5.9 & 5.5 & 5.9 & 6.3 & 6.7 & 6.9 & 7.0 & 6.8 & 7.0 \\
\hline
\end{tabular}

Sources: Ministry of Finance, Banco Central del Uruguay, and Fund staff estimates.

1/ Government guarantees on payments to BROU by BHU and AMC, assumed to be invoked fully.

2/ Includes release of principal and cash payments in debt exchange.
3/ Includes government guarantees to BROU (footnote 1), paid out as bonds, amounts as in line "bank assistance". 


\begin{tabular}{|c|c|c|c|c|c|c|c|c|c|c|c|c|}
\hline & \multirow[b]{2}{*}{2001} & \multicolumn{11}{|c|}{ Projections } \\
\hline & & 2002 & 2003 & 2004 & 2005 & 2006 & 2007 & 2008 & 2009 & 2010 & 2011 & 2012 \\
\hline \multicolumn{13}{|c|}{ A Assumptions } \\
\hline Real GDP growth (percent) & -3.4 & -10.8 & 1.0 & 5.0 & 4.0 & 4.0 & 3.0 & 3.0 & 3.0 & 2.5 & 2.5 & 2.5 \\
\hline Real U.S. dollar exchange rate (change in percent) & -13.8 & -26.8 & -14.0 & 1.6 & 6.3 & 4.4 & 4.2 & 1.4 & 0.0 & 0.0 & 0.0 & 0.0 \\
\hline Primary balance: Consolidated public sector & -1.2 & 0.4 & 2.8 & 3.2 & 3.3 & 3.3 & 3.8 & 3.8 & 3.8 & 3.8 & 3.8 & 3.8 \\
\hline Non-financial public sector & -1.0 & 0.5 & 2.9 & 3.4 & 3.5 & 3.5 & 4.0 & 4.0 & 4.0 & 4.0 & 4.0 & 4.0 \\
\hline $\mathrm{BCU}$ & -0.2 & -0.1 & -0.2 & -0.2 & -0.2 & -0.2 & -0.2 & -0.2 & -0.2 & -0.2 & -0.2 & -0.2 \\
\hline Overall Balance: Consolidated public sector & -4.2 & -4.5 & -3.4 & -3.3 & -2.2 & -2.1 & -1.6 & -1.6 & -1.5 & -1.4 & -1.1 & -1.0 \\
\hline Non-financial public sector & -3.7 & -4.2 & -2.8 & -2.1 & -1.4 & -1.3 & -0.8 & -0.8 & -0.7 & -0.6 & -0.3 & -0.2 \\
\hline $\mathrm{BCU}$ & -0.3 & -0.3 & -0.6 & -1.2 & -0.8 & -0.8 & -0.8 & -0.8 & -0.8 & -0.8 & -0.8 & -0.8 \\
\hline \multicolumn{13}{|c|}{ B. Debt Dynamics (in percent of GDP) } \\
\hline Gross non-financial public sector debt & 45 & 89 & 98 & 94 & 88 & 80 & 74 & 70 & 67 & 65 & 63 & 60 \\
\hline \multicolumn{13}{|c|}{ C. Cash Flow (in millions of U.S. dollars) } \\
\hline Gross borrowing needs & 1200 & 3278 & 1063 & 763 & 972 & 1516 & 1261 & 861 & 746 & 739 & 1325 & 977 \\
\hline Augmented public sector deficit & 700 & 2510 & 315 & 244 & 181 & 135 & 71 & 103 & 127 & 115 & 63 & 50 \\
\hline Public sector deficit & 700 & 512 & 315 & 254 & 181 & 185 & 121 & 133 & 127 & 115 & 63 & 50 \\
\hline Amortization & 500 & 768 & 748 & 519 & 791 & 1381 & 1190 & 758 & 619 & 624 & 1261 & 927 \\
\hline Bonds, long-term & 403 & 349 & 257 & 25 & 123 & 108 & 104 & 236 & 209 & 353 & 972 & 645 \\
\hline Commercial bank loans & 0 & 214 & 217 & 38 & 31 & 12 & 8 & 4 & 4 & 9 & 16 & 7 \\
\hline IDB/WB and other official debt & 97 & 205 & 234 & 265 & 364 & 441 & 404 & 212 & 227 & 248 & 274 & 275 \\
\hline IMF & 0 & 0 & 40 & 192 & 273 & 820 & 674 & 306 & 179 & 13 & 0 & 0 \\
\hline Gross Financing & 1199 & 3278 & 1062 & 763 & 714 & 780 & 742 & 451 & 411 & 434 & 460 & 461 \\
\hline Short-term bonds (net) & -32 & 383 & 244 & 25 & 100 & 100 & 100 & 50 & 0 & 0 & 0 & 0 \\
\hline Long-term bonds & 1292 & 143 & 405 & 246 & 250 & 250 & 250 & 200 & 200 & 200 & 200 & 200 \\
\hline Commercial bank loans & 85 & 0 & -288 & 200 & 0 & 0 & 0 & 0 & 0 & 0 & 0 & 0 \\
\hline IDB/WB and other official debt & 198 & 789 & 467 & 292 & 364 & 430 & 392 & 201 & 211 & 234 & 260 & 261 \\
\hline IMF & 0 & 1302 & 0 & 0 & 0 & 0 & 0 & 0 & 0 & 0 & 0 & 0 \\
\hline Central bank credit (net) & 7 & 665 & 297 & 0 & 0 & 0 & 0 & 0 & 0 & 0 & 0 & 0 \\
\hline Other inflows (net) & -351 & -3 & -63 & 0 & 0 & 0 & 0 & 0 & 0 & 0 & 0 & 0 \\
\hline Residual financing needs & $\mathbf{0}$ & $\mathbf{0}$ & $\mathbf{0}$ & $\mathbf{0}$ & 258 & 737 & 519 & 410 & 335 & 305 & 865 & 516 \\
\hline \multicolumn{13}{|c|}{ D. Other Indicators } \\
\hline Total debt service (in percent of GDP) & 5.5 & 10.7 & 12.3 & 9.8 & 10.9 & 14.2 & 12.3 & 9.3 & 8.2 & 8.0 & 10.8 & 8.8 \\
\hline Residual financing needs (in percent of GDP) & 0.0 & 0.0 & 0.0 & 0.0 & 2.0 & 5.0 & 3.3 & 2.4 & 1.9 & 1.6 & 4.5 & 2.5 \\
\hline Average interest rate (in percent) & 6.3 & 4.9 & 5.8 & 5.9 & 5.6 & 6.0 & 6.4 & 6.8 & 7.0 & 7.1 & 6.9 & 7.0 \\
\hline
\end{tabular}

Sources: Ministry of Finance, Banco Central del Uruguay, and Fund staff estimates.

$1 /$ Government guarantees on payments to BROU by BHU and AMC, assumed to be invoked fully

2/ Includes release of principal and cash payments in debt exchange. 


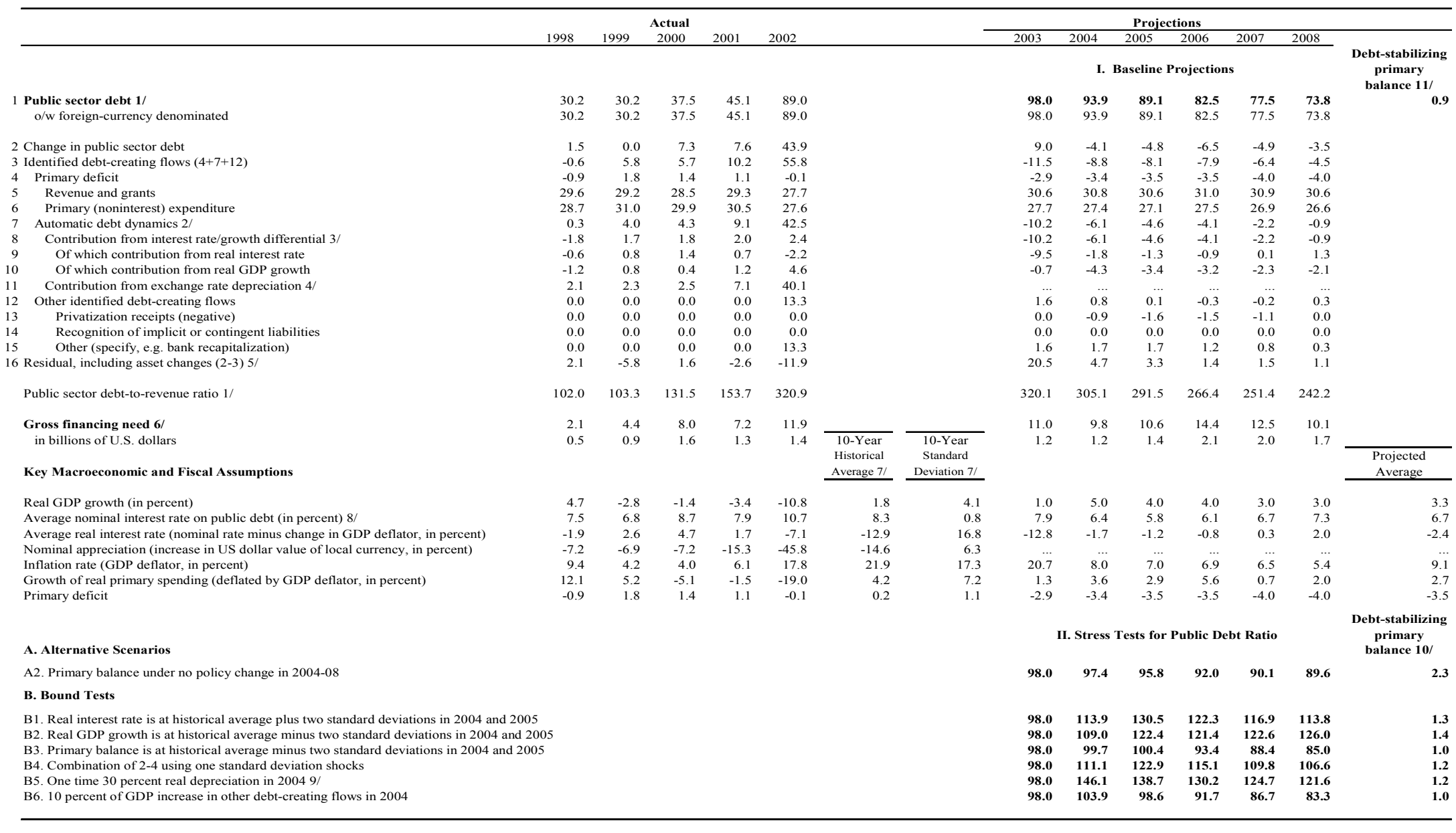

1/ Indicate coverage of public sector, e.g., general government or nonfinancial public sector. Also whether net or gross debt is used
$2 /$ Derived as $[(r-\pi(1+g)-g+\alpha \varepsilon(1+r)](1+g+\pi+g \pi))$ times previous period debt ratio, with $r=$ interest rate; $\pi=$ growth rate of GDP

denominated debt; and $\varepsilon=$ nominal exchange rate depreciation (measured by increase in local currency value of U.S. dollar).

3/ The real interest rate contribution is derived from the denominator in footnote $2 /$ as $\mathrm{r}-\pi(1+\mathrm{g})$ and the real growth contribution as $-\mathrm{g}$.

4/ The exchange rate contribution is derived from the numerator in footnote $2 /$ as $\alpha \varepsilon(1+\mathrm{r})$.

6/ Defing a

.

8/ Derived as nominal interest expenditure divided by previous period debt stock.

9/ Real depreciation is defined as nominal depreciation (measured by percentage fall in dollar value of local currency) minus domestic inflation (based on GDP deflator).

10/ Assumes that key variables (real GDP growth, real interest rate, and primary balance) remain at the level in percent of GDP/growth rate of the last projection year. 


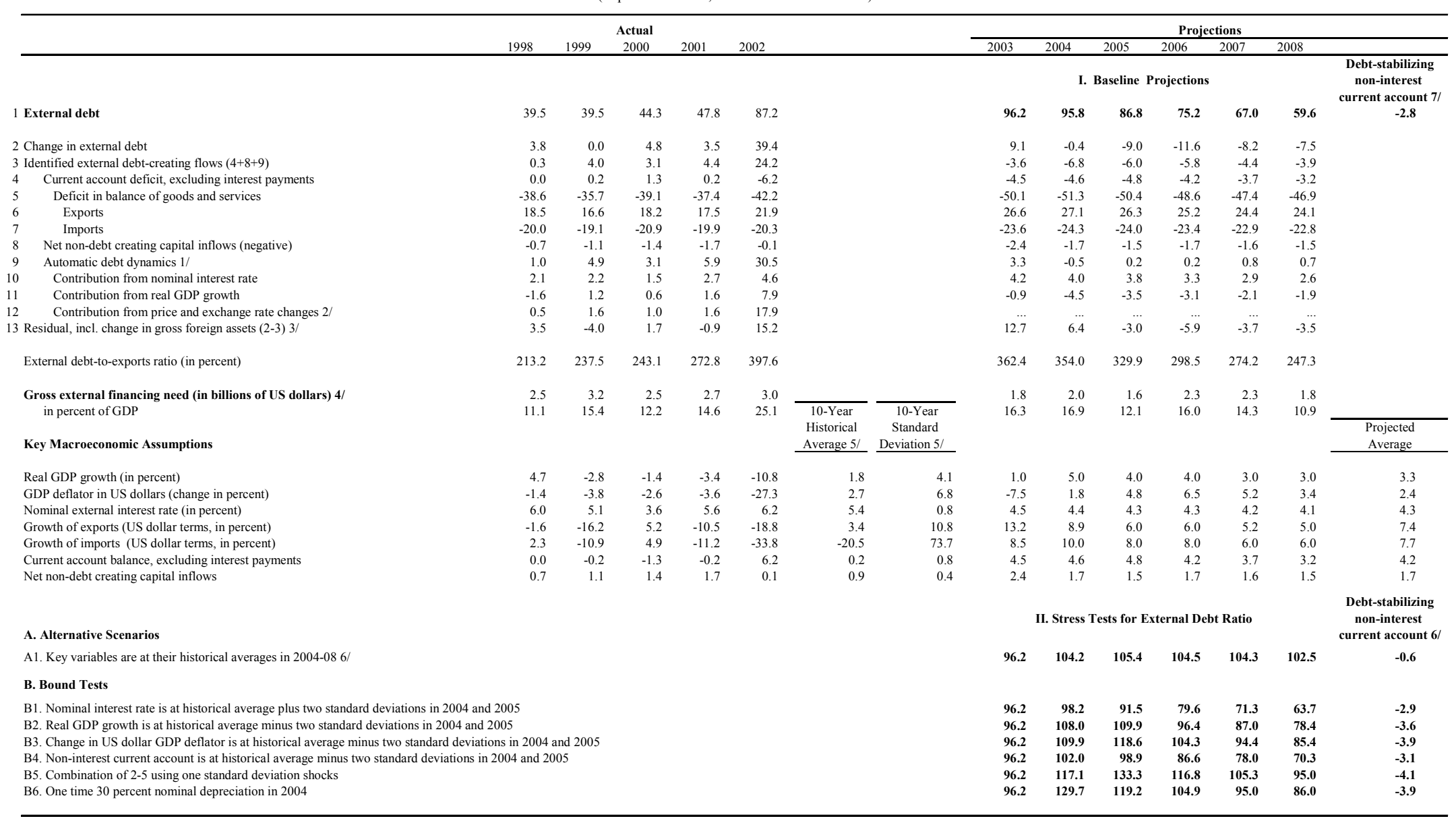

$1 /$ Derived as $[\mathrm{r}-\mathrm{g}-\rho(1+\mathrm{g})+\varepsilon \alpha(1+\mathrm{r})](1+\mathrm{g}+\rho+\mathrm{g} \rho)$ times previous period debt stock, with $\mathrm{r}=$ nominal effective interest rate on external debt; $\rho=$ change in domestic GDP deflator in US dollar terms, $\mathrm{g}=$ real GDP growth rate, $\mathrm{e}=$ nominal appreciation (increase in dollar value of domestic currency), and $\mathrm{a}=$ share of domestic-currency denominated debt in total external deb.

and rising inflation (based on GDP deflator).

ludes price and exchange rate changes

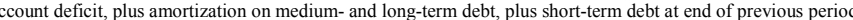

6/ The key variables include real GDP growth; nominal interest rate; dollar deflator growth; and both non-interest current account and non-debt inflows in percent of GDP. 
URUGUAY-FUND RELATIONS

(As of December 30, 2003)

I. Membership Status: Joined March 11, 1946; Article VIII

\section{A. Financial Relations}

II. General Resources Account:

Quota

Fund holdings of currency

Reserve position

III. SDR Department:

Net cumulative allocation

Holdings

IV. Outstanding Purchases and Loans:

Stand-by arrangements
In millions

of SDRs

306.50

$1,932.41$

0.0

In millions

of SDRs

49.98

2.52

In millions

of SDRs

$1,625.90$
In percent of quota

100.0

630.48

0.0

Percent of allocation

100.0

5.04

In percent

of quota

530.47

V. Financial Arrangements:

$\underline{\text { SDR Millions }}$ Approval Expiration Amount Amount

Type

Date

Date Approved

$\underline{\text { Drawn }}$

Stand-by

$4 / 01 / 02$

$3 / 31 / 05$

$2,128.30$

$1,475.90$

Of which SRF

$6 / 25 / 02$

$8 / 08 / 02$

128.70

128.70

Stand-by

$5 / 31 / 00$

$5 / 31 / 02$

150.00

150.00

Stand-by

$3 / 29 / 99$

$3 / 28 / 00$

70.00

0.00

VI. Projected Obligations to Fund: (Obligation Basis) (SDR millions; based on existing use of resources and present holdings of SDRs):

Forthcoming

$\underline{2004} \quad \underline{2005} \quad \underline{2006} \quad \underline{2007} \quad \underline{2008}$

Principal

$\begin{array}{lllll}128.70 & 226.63 & 666.65 & 521.98 & 81.95\end{array}$

Charges/interest

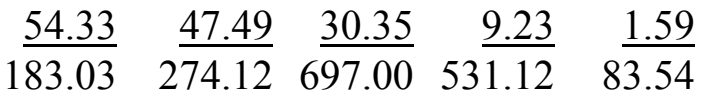

Total 


\section{B. Nonfinancial Relations}

VII. Safeguards Assessment: An on-site assessment of the BCU was conducted in July 2002, and the final safeguards assessment report was approved by management in January 2003. The assessment identified a need to strengthen the control and oversight framework within the BCU, in particular in the external audit area. To this end, staff recommended the establishment of an audit committee, the hiring of a private audit firm with international affiliation to perform a financial audit of the BCU, and the establishment of similar external audit procedures for the FSBS. The authorities are committed to the implementation of all the safeguards recommendations, including an external audit of the FSBS which was completed on September 30, 2003. A supplementary external audit of the FSBS will be completed by March 31, 2004; and an external audit of the BCU's 2003 accounts by June 30, 2004.

VIII. Exchange Rate Arrangement: The currency is the Uruguayan peso (Ur\$). Uruguay has followed an independently floating exchange rate regime since July 29, 2002. On December 31, 2003, buying and selling interbank rates for the U.S. dollar, the intervention currency, were Ur\$30.28 and Ur\$30.33, respectively. Uruguay's exchange system is mostly free of restrictions on payments and transfers for current international transactions. However, the reprogramming of time deposits at BROU and BHU gives rise to an exchange restriction under Article VIII, as it prevents nonresidents affected by the reprogramming from transferring abroad proceeds of recent current international transactions. Staff has recommended approval of the exchange restriction, given that it is temporary and does not discriminate among Fund members.

IX. Article IV Consultation: The 2003 Article IV consultation was concluded by the Executive Board on July 11 (Country Report No. 03/247). Uruguay is on the standard consultation cycle approved on July 15, 2002.

X. FSAP participation, ROSCs, and OFC Assessments: The ROSC-module on fiscal transparency was published on March 5, 2000. A ROSC module on data dissemination practices was published on October 18, 2001. The FSAP exercise started in November 2001; its completion has been delayed until the situation stabilizes.

XI. Technical Assistance: Technical assistance in tax policy and tax administration was provided by FAD in May and July 2003. In April 2003, STA provided technical assistance on adequate recording of loans funded by the FSBS. MFD has been providing substantial technical assistance since 2002 in the resolution of intervened banks and the restructuring of the public bank BROU.

XII. Resident Representative: Mr. Andreas Bauer 


\section{RELATIONS WITH THE WORLD BANK GROUP}

The Board considered the last Country Assistance Strategy (CAS) on May 5, 2000 and the CAS Progress Report on July 25, 2002. The Bank increased its financial support, shifting to a high case plus lending scenario (\$550 million for fiscal years 2003-04) concentrated in adjustment lending. A Structural Adjustment Loan and a Special Structural Adjustment Loan were approved, totaling US\$303 million, to assist Uruguay in addressing structural weaknesses and in managing the economic crisis. On April 8, 2003, another package of Structural Adjustment and Special Structural Adjustment Loans totaling US\$252.5 million was approved, focusing on improving public services. Second tranche releases for these operations are still pending. New investment operations have been postponed until FY05.

The investment portfolio comprises eight projects totaling US\$382 million in commitments, concentrated in the infrastructure sector ( 76.7 percent). The level of project execution has deteriorated as a result of the crisis, mostly because of budgetary restrictions. The latest Portfolio Review (July 2003) also pointed to the need to streamline procurement processes.

\section{FINANCIAL RELATIONS WITH THE WORLD BANK GROUP}

(As of October 31, 2003; in millions of U.S. dollars)

\begin{tabular}{lccc}
\hline & \multicolumn{3}{c}{ Commitments } \\
\cline { 2 - 4 } & Net of & & \\
Andisbursed & Actual & Remaining \\
& Cancellations & Disbursements & Amount \\
\hline
\end{tabular}

I. IBRD Operations (as of November 15, 2003)

$\begin{array}{lrrr}\text { Agriculture } & 18.5 & 12.4 & 6.1 \\ \text { Central government and administration } & 555.6 & 280.6 & 275.0 \\ \text { Telecommunication } & 6.0 & 0.9 & 5.1 \\ \text { Education } & 70.0 & 31.2 & 38.8 \\ \text { Power } & 125.0 & 67.3 & 57.7 \\ \text { Transportation } & 71.0 & 37.6 & 33.4 \\ \text { Water supply } & 27.0 & 4.6 & 22.4 \\ \text { Total } & \mathbf{8 7 3 . 1} & \mathbf{4 3 4 . 6} & \mathbf{4 3 8 . 5}\end{array}$

II. IFC Operations (as of October 31, 2003)

$\begin{array}{lrrrr} & \text { Loans } & \text { Equity } & \text { Quasi } & \text { Participation } \\ \text { Held } & 27.9 & 4.2 & 13.4 & 0.9 \\ \text { Disbursed } & 16.2 & 4.2 & 13.4 & 0.9\end{array}$

III. IBRD Loan Transactions (calendar year)

\begin{tabular}{lrrrrrrrrrr} 
& $\mathbf{1 9 9 4}$ & $\mathbf{1 9 9 5}$ & $\mathbf{1 9 9 6}$ & $\mathbf{1 9 9 7}$ & $\mathbf{1 9 9 8}$ & $\mathbf{1 9 9 9}$ & $\mathbf{2 0 0 0}$ & $\mathbf{2 0 0 1}$ & $\mathbf{2 0 0 2}$ & $\mathbf{2 0 0 3}$ \\
Disbursements & 37.0 & 31.7 & 38.7 & 50.4 & 143.9 & 66.3 & 134.2 & 64.7 & 233.5 & 93.7 \\
Repayments & 56.2 & 77.8 & 69.7 & 67.9 & 64.1 & 63.2 & 57.9 & 72.5 & 75.3 & 64.3 \\
Net Lending & -19.2 & -46.1 & -31.0 & -17.5 & 79.8 & 3.1 & 76.3 & -7.8 & 158.2 & 29.4 \\
\hline
\end{tabular}

Source: World Bank. 


\section{RELATIONS WITH THE INTER-AMERICAN DEVELOPMENT BANK}

The most recent IDB Country Strategy for Uruguay focuses on the following priority areas for the Bank's action: (i) enhancing the regional and international competitiveness of domestic output and encouraging private investment, in order to foster healthy competition and allow for integration with both the regional and international markets; (ii) deepening the reform of the State, with a view to rationalizing expenditure, targeting interventions, and reducing its role in the production of domestic goods and services; and (iii) improving social welfare and increasing equity, particularly to those families and children living in poverty.

As of January 5, 2004 the Bank's active portfolio in Uruguay included 20 loans for the financing of investment projects; one sector loan, for Strengthening the Banking Sector; and 30-nonreimbursable technical cooperation operations for US\$17 million. The lending portfolio amounts to US\$1,162 million, of which US\$499 million are pending disbursement. The IDB's tentative lending program for 2004 includes financing for a Program to Support Employment Generation for US\$80 million; a Highway Infrastructure Program for US\$70 million; a Cattle Development Program for US\$25 million; and a loan by the Department of the Private Sector under the Trade Financing Facility (ABN-AMRO) for US\$12.5 million.

\section{FINANCIAL RELATIONS WITH THE INTER-AMERICAN DEVELOPMENT BANK}

(As of November 30, 2003; in millions of U.S. dollars)

Total outstanding loans: US\$2,131.9

Loan transactions:

\begin{tabular}{lccccccc}
\hline & $\mathbf{1 9 9 7}$ & $\mathbf{1 9 9 8}$ & $\mathbf{1 9 9 9}$ & $\mathbf{2 0 0 0}$ & $\mathbf{2 0 0 1}$ & $\mathbf{2 0 0 2}$ & $\mathbf{2 0 0 3}$ \\
\hline Disbursements & 178.7 & 150.8 & 358.5 & 162.9 & 214.2 & 558.6 & 362.0 \\
Amortization & 45.7 & 48.3 & 57.0 & 59.4 & 60.7 & 73.1 & 87.0 \\
Net Loan Flows & $\mathbf{1 3 3 . 0}$ & $\mathbf{1 0 2 . 5}$ & $\mathbf{3 0 1 . 5}$ & $\mathbf{1 0 3 . 5}$ & $\mathbf{1 5 3 . 5}$ & $\mathbf{4 8 5 . 5}$ & $\mathbf{2 7 5 . 0}$ \\
\hline
\end{tabular}

Source: Inter-American Development Bank. 


\section{URUGUAY: STATISTICAL ISSUES}

The statistical database in Uruguay is generally adequate for the assessment and monitoring of macroeconomic policies. The multisector mission of November 10-24,1999 developed an action plan that includes recommendations for bringing Uruguay's data dissemination policies and practices into line with the Fund's Special Data Dissemination Standard (SDDS). The authorities have made significant progress in implementing the mission's recommendations, both with respect to timeliness of dissemination of the SDDS data categories, and in terms of methodological changes to improve data quality. During a staff visit to Montevideo (April 5$6,2001)$ to present the findings of the data module of the Report on Observance of Standards and Codes (ROSC), the Uruguayan authorities reiterated their commitment to subscribe to the SDDS in the near future. An SDDS mission visited Montevideo (December 5-14, 2001) to assist the authorities in finalizing their work toward subscription to the SDDS.

\section{Real sector}

National account statistics have a number of shortcomings, including the use of an outdated benchmark year 1983, limited coverage of the enterprise survey, long publication lags, inadequate information on the informal economy, and incomplete quarterly accounts. The BCU compiles and disseminates annual GDP estimates in current and constant prices by production and expenditure approach, as well as quarterly constant price GDP estimates by production and expenditure approach. Gross national income, gross disposable income and gross savings are also available annually. The November 1999 multisector mission recommended a range of improvements including the completion of the revision of data and methods that had already been partially carried out, introduction of annually chained volume measures, incorporation of new benchmark survey data, and compilation of quarterly estimates of GDP at current prices.

The authorities do not provide trade price and volume indices for publication in the International Financial Statistics (IFS).

Both the consumer and wholesale price indices are reported on a regular and timely basis for publication in the IFS. The consumer price index has a base period of March $1997=100$, and the wholesale price index has a base of January $1988=100$. The coverage of the CPI is limited to the capital city.

\section{Government finances}

Official data on the central administration, the state enterprises and the social security system are complete and current, but there are problems with the currentness of the data on the local governments; there are also problems with the currentness of the financing and debt data reported for inclusion in the Fund's statistical publications. The multisector mission that visited Uruguay in November 1999 reviewed the sources used for the compilation of central government financing and identified sources of information for local governments. The 
mission made recommendations for the compilation of these data and their reporting to STA. The information reported for publication in the Government Finance Statistics Yearbook includes data on the central government; however, complete annual central government debt data have not been reported for periods after 1994 and data on local governments have not been reported for periods after 1997.

\section{Monetary accounts}

Two STA money and banking statistics missions visited Montevideo in July 1998 and March 1999. The missions reviewed the currentness, coverage, and classification of the monetary accounts for the banking system and developed a unified system for reporting data to the Fund. The 1999 multisector mission continued work on improving the basic source data and the methodology for compiling monetary statistics, and recommended a new reporting system, which has since been adopted by the Central Bank. The mission developed a database that contains the data needs for publication in IFS and for operational use by WHD.

The STA mission that visited Montevideo in April 2003 provided recommendations for the adequate recording of the loans funded from the Fund for the Stabilization of the Banking System in the Central Bank's balance sheet. The mission's recommendations have been implemented and were reflected in the IFS June 2003 issue.

\section{Balance of payments}

Balance of payments statements are compiled and published on a quarterly basis. Data are compiled following the recommendations of the fifth edition of the Balance of Payments Manual (BPM5). The authorities have made significant progress in implementing the mission recommendations in order to improve the coverage and quality of the balance of payments estimates. The directory of direct investment enterprises have been updated and measures have been introduced to improve the survey on inward investment; quarterly surveys have been introduced in the case of services, and other activities not currently covered; the coverage of reserve assets has been revised to exclude certain assets that are not available to finance balance of payments needs. Uruguay compiles and reports to STA annual data on balance of payments and the international investment position (IIP) for publication in the IFS and the Balance of Payments Statistics Yearbook. The new surveys would also allow for improved coverage of the private sector in the IIP.

In October 2003, Uruguay disseminated the international reserves and foreign currency liquidity data template on the Central Bank's website for the first time. Monthly information on the data template is currently available for August-November 2003. 
URUGUAY: Core Statistical Indicators

(as of February 3, 2004)

\begin{tabular}{|c|c|c|c|c|c|c|c|c|c|c|c|c|}
\hline & $\begin{array}{l}\text { Exchange } \\
\text { Rates }\end{array}$ & $\begin{array}{l}\text { International } \\
\text { Reserves }\end{array}$ & $\begin{array}{l}\text { Reserve/ } \\
\text { Base } \\
\text { Money }\end{array}$ & $\begin{array}{l}\text { Central } \\
\text { Bank } \\
\text { Balance } \\
\text { Sheet } \\
\end{array}$ & $\begin{array}{l}\text { Broad } \\
\text { Money }\end{array}$ & $\begin{array}{l}\text { Interest } \\
\text { Rates }\end{array}$ & $\begin{array}{l}\text { Consumer } \\
\text { Price } \\
\text { Index }\end{array}$ & $\begin{array}{l}\text { Exports/ } \\
\text { Imports }\end{array}$ & $\begin{array}{l}\text { Current } \\
\text { Account } \\
\text { Balance }\end{array}$ & $\begin{array}{l}\text { Overall } \\
\text { Government } \\
\text { Balance }\end{array}$ & GDP/GNP & $\begin{array}{l}\text { External } \\
\text { Public } \\
\text { Debt }\end{array}$ \\
\hline $\begin{array}{l}\text { Date of latest } \\
\text { observation }\end{array}$ & $01 / 29 / 04$ & 01/29//04 & $01 / 29 / 04$ & $12 / 03$ & $11 / 03$ & $01 / 29 / 04$ & $12 / 03$ & $\begin{array}{c}10 / 03(\mathrm{X}) \\
11 / 03(\mathrm{M})\end{array}$ & $10 / 03$ & $11 / 03$ & Q3 03 & $09 / 03$ \\
\hline Date received & $02 / 02 / / 04$ & $02 / 02 / 04$ & $01 / 25 / 04$ & $01 / 29 / 04$ & $01 / 20 / 04$ & $02 / 02 / 04$ & $01 / 15 / 04$ & $01 / 04$ & $01 / 04$ & $01 / 04$ & $12 / 03$ & $12 / 03$ \\
\hline Frequency of data & Daily & Daily & Daily & Monthly & Monthly & Daily & Monthly & Monthly & Quarterly & Monthly & Quarterly & Quarterly \\
\hline $\begin{array}{l}\text { Frequency of } \\
\text { reporting }\end{array}$ & Daily & Daily & Daily & Monthly & Monthly & Daily & Monthly & Monthly & Quarterly & Monthly & Quarterly & Quarterly \\
\hline Source of data & Central Bank & Central Bank & Central Bank & Central Bank & $\begin{array}{c}\text { Central } \\
\text { Bank }\end{array}$ & $\begin{array}{c}\text { Central } \\
\text { Bank }\end{array}$ & $\begin{array}{c}\text { Institute of } \\
\text { Statistics }\end{array}$ & $\begin{array}{c}\text { Central } \\
\text { Bank }\end{array}$ & $\begin{array}{c}\text { Central } \\
\text { Bank }\end{array}$ & $\begin{array}{l}\text { Ministry of } \\
\text { Finance }\end{array}$ & $\begin{array}{c}\text { Central } \\
\text { Bank }\end{array}$ & $\begin{array}{c}\text { Central } \\
\text { Bank }\end{array}$ \\
\hline Mode of reporting & E-mail & E-mail & E-mail & E-mail & E-mail & E-mail & Web & Web & $\begin{array}{c}\text { E-mail/ } \\
\text { Web }\end{array}$ & $\begin{array}{c}\text { E-mail/ } \\
\text { Web }\end{array}$ & $\begin{array}{c}\text { E-mail/ } \\
\text { Web }\end{array}$ & Web \\
\hline Confidentiality & None & None & None & None & None & None & None & None & None & None & None & None \\
\hline $\begin{array}{l}\text { Frequency of } \\
\text { Publication }\end{array}$ & Daily & Daily & Monthly & Monthly & Monthly & Daily & Monthly & Monthly & Monthly & Monthly & Quarterly & Monthly \\
\hline
\end{tabular}


INTERNATIONAL MONETARY FUND

\title{
URUGUAY
}

\begin{abstract}
Fourth Review Under the Stand-By Arrangement and Requests for Modification of the Arrangement and Waiver of Nonobservance and Applicability of Performance Criteria; and Extension of Repurchase Expectations in the Credit Tranches
\end{abstract}

\section{Supplementary Information}

Prepared by the Western Hemisphere Department

(In consultation with other Departments)

Approved by Markus Rodlauer and Liam P. Ebrill

February 18, 2004

1. Since the issuance of the staff report, additional information on recent developments and policy measures has become available. This information does not alter the thrust of the staff's appraisal.

2. Prior actions and structural performance criteria. The three prior actions for completing the fourth review have been observed:

- $\quad$ The authorities have selected a general manager of the fiduciary trust to which BROU's nonperforming loans have been transferred.

- The central government has issued an unconditioned guarantee for the notes to be issued by the fiduciary trust in exchange for the loans transferred from BROU.

- On February 13, the authorities solicited bids for outsourcing the assets of the liquidated banks, with the opening of bids scheduled for March 26. Under this schedule, the authorities will not be able to observe the end-February structural performance criterion on the selection of the winning bid for outsourcing of assets of liquidated banks. In the attached letter, they request that the date for observance of this structural performance criterion be changed to end-March 2004. Staff supports the request, given the brief delay and the authorities' overall commitment to banking reform. A revised proposed decision is attached.

3. Quantitative performance criteria. Available data for end-December indicate that the quantitative performance criterion on general government noninterest expenditure was observed with a small margin. However, because these data are still preliminary, the authorities maintain their request for a waiver of applicability. 
4. Economic and financial developments. In December, output in the manufacturing industry rose 37 percent in real terms (year-on-year). The index of leading indicators of activity compiled by a local think tank (CERES) rose by 1.4 percent (seasonally adjusted, month-on-month), suggesting that growth is continuing in early 2004. Inflation remained broadly in line with program projections in January; a 2.2 percent increase in the CPI $(\mathrm{m} / \mathrm{m})$ reflected mostly adjustments in the tariffs charged by public utilities, with the 12-month rate rising only slightly, to 10.5 percent. Deposits of the non-financial private sector in the Uruguayan banking sector have also continued to recover in January (an increase of US\$168 million, or 2.5 percent).

5. Subscription to the SDDS. On February 12, the authorities formalized their subscription to the SDDS. An SDDS website for Uruguay is now in operation. 
Montevideo, Uruguay

February 17, 2004

Dear Mr. Köhler:

As anticipated in our letter of February 6, 2004, the call for bids for the outsourcing of assets of liquidated banks, which was a prior action under the program, was issued last week. However, delays were registered in assembling the required bidding information, and bidders will need sufficient time to conduct due diligence prior to the auction. As a consequence, it will no longer be possible to select the winning bid at end-February as originally contemplated. We therefore request that the end-February structural performance criterion on selecting a winning bid for outsourcing assets of liquidated banks be instead established as a performance criterion for end-March 2004. We remain fully committed to the banking strategy set forth in our letter of February 6, 2004.

Sincerely yours,

\author{
$/ \mathrm{s} /$ \\ Julio de Brun \\ President \\ Central Bank of Uruguay
}

\author{
$/ \mathrm{s} /$ \\ Isaac Alfie \\ Minister of Economy and Finance \\ Oriental Republic of Uruguay
}

Mr. Horst Köhler

Managing Director

International Monetary Fund

700 19th Street, N.W.

Washington, D.C. 20431 


\section{Statement by Guillermo Le Fort, Executive Director for Uruguay and David Vogel, Senior Advisor to Executive Director February 20, 2004}

\section{Key Points}

- After a 4 year recession, the Uruguayan GDP is growing robustly.

- Respect for property rights, predictability, avoidance of perverse incentives and prudent macroeconomic management define the policy framework.

- The voluntary financial de-dollarization of the financial system continues to advance, but the focus of financial reforms is on restructuring the BROU. Despite delays, substantial progress has been made since August 2002.

- To enhance efficiency, private sector participation in the economy has been stimulated through concessions, while the authorities continue their strategy to fully integrate Uruguay into the global economy.

1. At the outset, and on behalf of the Uruguayan authorities, we would like to once again thank Management and Staff for their continued involvement with the efforts of our authorities to stabilize the Uruguayan economy. We also thank the Executive Board for their support to the program that has allowed Uruguay to overcome the worst financial crisis in its history, and initiate an impressive recovery.

\section{Background and Recent Developments}

2. Uruguay's economic program has been framed around the respect for property rights, the predictability of the rules of the game, as well as the avoidance of perverse incentives, and expressed in ambitious macroeconomic targets that led to a prudent management of monetary and fiscal policy. This has been manifested by the debt exchange operation, characterized in the last issue of Euromoney, as one of the smoothest and most elegant operations seen in international finance, which constituted a turning point in the crisis. In addition, the rapid fall of inflation, the stabilization of the exchange rate, the reduction of country risk to about 600 basis points from about 2.200 in February 2003, the recovery of local deposits and economic activity also attested to the success of our authorities' efforts.

3. After four years of recession and falling GDP, the Uruguayan economy grew robustly in the second part of 2003, leading to an annual growth rate of above 1 percent. It is worth noting that the recovery in economic activity exceeded program projections made early last year (-2 percent), and most notably the original program projections defined in $2002(-4.5$ percent). These better than expected results should help to overcome the skepticism about the results that a well designed program and the financial support of the international community can achieve.

4. Growth has been led by exports, particularly to markets outside the region. The rapid growth of exports of goods and services is partly the response to a substantially improved external environment as compared to the past few years, during which the country was 
continuously affected by adverse external shocks. Higher global growth has resulted in better export prices, the regional recovery has been critical for tourism activity that continues to accelerate, and lower risk aversion has allowed a significant reduction in the cost of external financing. However, beyond the more favorable external environment, clearly, the increase in competitiveness accomplished in recent years has been critical for boosting exports.

5. Although not as fast as exports, domestic demand is also picking-up, in part, through the incipient recovery of credit to the private sector. As the staff note, the 2002 financial crisis caused a sharp drop in consumer spending, mostly associated with a wealth effect and credit contraction. However, to the extent that the measures resulted in fewer losses to depositors and bondholders than they previously expected, the wealth effect has been receding. Furthermore, official figures are showing increasing activity in the real estate market that could eventually result in a rebound of asset prices, favoring a higher wealth perception and consumption growth. Investment, that was also severely reduced by the deep recession, has been, as is often the case, the last demand component to initiate the recovery. Nonetheless, since uncertainties have been significantly reduced under policies that have demonstrated once again a serious commitment with a friendly business environment, and the credit crunch has been largely overcome, it is possible to foresee a recovery in investment, once the sizeable output gap resulting from the past recession is sufficiently absorbed. There are already strong signals of a recovery of investments in the infrastructure and agricultural sectors.

6. The recovery has been accompanied by a strong increase in employment of 5.5 percent, and a reduction in the unemployment rate to 15.4 percent in the last quarter of 2003, compared to 18.6 percent in the same period of the previous year, and also by a substantial reduction in the average period of joblessness. At the same time, the inflation rate has fallen to somewhat above 10 percent from nearly 30 percent a year ago, much lower than projected under the program.

\section{Fiscal Policy}

7. Encouraged by the fiscal achievements in 2003, that represented a turn around of about 3 percent of GDP in the primary fiscal balance, to a surplus of about 3 percent, the authorities are fully committed to achieving this year's objective. The fiscal target for 2003 was marginally missed as a result of lower than expected nominal revenues owing to lower than programmed inflation and wages and also higher international oil prices. The expenditure targets were met and non-interest expenditure fell by 3 percentage points of GDP in 2003, and will continue decreasing this year. Meanwhile, the interest burden envisaged at 6.6 percent of the GDP, was 5.9 percent of the GDP more than offsetting the slight deviation of the primary fiscal surplus. At the same time, social expenditures will continue to be protected, while the authorities keep on working to enhance the efficiency of social policies. It is also expected that the modernization of the Tax Administration Department, in line with FAD technical assistance recommendations could strengthen tax administration and increase revenues. Nonetheless, the authorities will continue working toward a broader reform aimed at rationalizing the tax system and improving tax collection, even though they recognize the constraints engendered by current political environment. Though the authorities consider 
that the planned restraint in the expenditure and projected increase of revenues will be sufficient to reach the primary surplus objectives, they agree to keep the adequacy of the fiscal surplus target under continuous review to ensure debt sustainability.

8. Precisely, regarding debt sustainability, Appendix III of the staff report starts underscoring that at end-2003, Uruguay's debt-to-GDP ratio was close to 100 percent of GDP, more than double its level at end-2001. The increase in debt reflects the severe impact of the crisis that will require sustained policies to be reversed. Our authorities remain convinced that by maintaining a prudent fiscal policy that is consistent with economic growth and poverty reduction, debt sustainability indicators will improve and market access fully regained. The baseline medium-term scenarios for public sector debt show a substantial reduction in the debt-to-GDP ratio. Moreover, looking at the debt issue from a dynamic point of view, it is important to consider that since 2001 Uruguay has overcome the constraints to growth imposed by the appreciated exchange rate, making further real exchange rate depreciation quite unlikely to the extent that the program continues to be implemented. Furthermore, the crisis implied the realization of contingent liabilities related to banking, while the policies implemented, as a response, have further reduced those remaining. All in all, the probability of occurrences of scenarios that superimpose large adverse shocks to an economy that is recovering from previous ones is much lower than in the standard case. As the staff clearly point out, some of the stress tests appear inappropriately pessimistic in light of the fact that Uruguay is just emerging from a crisis.

\section{Monetary Policy}

9. A strong increase of the Central Bank's international reserves has taken place. Gross reserves increased from US\$ 555 million in February 2003 to US\$ 2,100 million at present, requiring a greater use of monetary instruments to sterilize the monetary impact of the reserve accumulation. Base money growth has been contained within the program's indicative targets. More importantly, the increased confidence on fiscal and monetary management has also been reflected in the increase in the maturity of the sterilization instruments. Whereas the Central Bank was issuing Treasury bills with an average maturity of 10 days in February 2003, currently these bills have an average maturity of 90 days. At the same time, a substantial reduction in the yield of Treasury bill denominated in local currency has taken place from about 70 percent one year ago to around 15 percent in recent auctions. Moreover, the Central Bank has continued with a weekly auction of inflation-indexed notes, which together with peso denominated liabilities now represents 15 percent of the stock of Notes and Bonds, in contrast to the 1 percent registered in 2002. In addition, in October, Uruguay resumed its access to international financial markets issuing a three-year pesodenominated and inflation-indexed bond.

10. A sustained increase in money demand, associated with the recovery of economic activity and the lower interest rates and inflationary expectations, has allowed a gradual reduction in reserve requirements on peso denominated deposits. This has contributed to initiate a voluntary de-dollarization of the financial system. Since last June, the reserve requirements have been reduced by about 10 percentage points for peso deposits with a maturity of less than 30 days, while requirements for 31 to 180 day peso deposits have been 
object of an even greater reduction. These measures contributed to an increase of more than 30 percent in peso denominated deposits in 2003, leading to a gradual recovery of the lending in local currency. Furthermore, some commercial banks have already announced their intention to launch inflation-indexed loans, thus substituting the foreign currency denominated loans in their lending operations.

11. It is the authorities' intention to base the monetary program on quantitative targets in 2004, while continuing forward to establish the foundations for adopting an inflationtargeting regime. The authorities agree that all the foundations for inflation targeting are not yet in place, as Box 5 of the staff report notes, but consider that the additional comments in the aforementioned Box do not exactly reflect the progress made in this area. In particular, the fiscal position and institutional framework have improved substantially, and Central Bank independence has been strengthened.

\section{Structural Reforms}

12. The Uruguayan authorities broadly agree with the staff's comments about the need to accelerate the reform process of the banking system and continue lowering financial vulnerabilities. They have been focusing greatly on the restructuring of the BROU. The fiduciary trust was established in December 2003, and a general manager was hired recently by the Bank, who will contract the specialized services of experienced professionals in dealing with non performing loans. Moreover, the strategic plan approved by the Executive Board of the bank aims at decreasing risk through sound practices to provide loans, as well as to monitor and recover them. Furthermore, some other measures including a rationalization plan will be carried out to reduce operating costs. The authorities believe that reforming the BROU will be crucial to change some behaviors related to creditor discipline and reducing moral hazard.

13. The authorities also agree on the importance of the transformation process of the mortgage bank, BHU. While they are fully aware of the challenges that the transformation of the BHU conveys, they consider fair to recognize the progress achieved since August 2002. Among other issues, the institution has almost halved its personnel from 1,400 employees less than two years ago to about 750 currently, and further cuts are expected this year, as its transformation into a non-bank entity will imply managing assets of only US\$ 80 million in contrast to the US\$2,000 million managed in the past. With regard to the liquidated banks, the launch of bids to outsource asset disposal for the three liquidated banks was carried out. The government-owned bank, created with part of the assets of three liquidated banks, has been able to attract new private sector deposits, and it is being offered for sale to some institutional investors. In the case of the fourth liquidated bank which was closed, the government is completing the sale of its remaining assets.

14. It is possible to find many explanations for the recall of a law that would have made it possible for the state oil company to engage in a partnership with the private sector, including the voter's reaction to the crisis and the harsh measures taken to confront those hard times. Obviously, the authorities regretted the result of the plebiscite, but on the positive side, they consider that this episode once again made evident that political disputes in 
Uruguay are solved through the democratic process, and that political stability is clearly one of the most important elements to attract investment. At the same time, the authorities remain convinced of the need to advance deregulation and opening-up activities to competition. To overcome reluctance to some structural changes, the authorities continue working on the development of strong regulatory agencies and promoting transparency and competition. In addition, and as the staff report underscores, the negotiations for a number of concessions to the private sector have been recently completed, including Montevideo's International Airport and two seaports. Similarly, two new ports are being developed by private companies and a tender has been issued for the rehabilitation of the public railroad, all of which will reinforce the momentum of some activities, like forestry, that has received a significant amount of foreign investment.

15. The free trade agreement with Mexico, the ongoing negotiations with the United States, and the recent visit of the Uruguayan President to Spain to invite local companies to invest in Uruguay under a friendly business environment, are part of the authorities' strategy to fully integrate the country in the global economy. Finally, few days ago, the authorities notified the Uruguay's subscription to the IMF's Special Data Dissemination Standard, which is a new step to improve the transparency and quality of the country's data, a critical condition to attract foreign investment. 


\section{Statement by the Authorities}

\section{Right of Reply Document}

Since the Staff Report for the Fourth Review Under the Stand-By Arrangement was issued in February 2004, critical advances have taken place in the restructuring process at the state bank BROU. In addition, several favorable developments have been observed in the financial system reflecting the economic recovery and the progress of reform efforts. The Uruguayan authorities would like to update relevant information and make some comments on the Appendix II of this document.

At end-September 2003, when the restructuring plan was initiated, BROU`s financial condition was poor: the Bank was suffering operating losses, had nonperforming loans to total loans ratio of 33 percent, its capital was barely above adequacy requirements, and faced potential liquidity problems. These problems were noticeable on both sides of the balance sheet, which were compounded by serious operating inefficiencies.

However, some figures have been revised since the issuance of the staff report. The return on total assets for 2003 was about 0.1 percent compared with a negative 1.5 percent estimated when the staff report was issued. Furthermore, the Bank met its capital adequacy requirements with an excess of 25 percent in September 2003, that margin increased to 29 percent in March 2004.

The authorities have developed a restructuring plan to address the balance sheet problems of BROU and assure its viability. The restructuring plan has entailed more favorable developments than the estimates used when the staff report was issued. BROU had an operating profit of $5 \%$ of capital in the first quarter of 2004 , the capital adequacy ratio is clearly above requirements, and liquidity conditions have improved.

The volume of NPLs and other nonperforming assets was excessive. However, after some steps envisaged in the restructuring program, the NPL ratio has already decreased sharply to 11 percent at the end of the first quarter, and it is estimated that it will continue to fall reaching about 10 percent by the end of 2004. At the same time, NPL ratio for BROU's private sector loans has significantly fallen to 25 percent at the end of the first quarter of 2004.

The second tranche of reprogrammed deposits, those falling due during August 2004 - July 2005 , have already been repaid. BROU has built up liquidity covering about two thirds of these deposits, and has been successful in retaining the first and second tranche. Despite this success, BROU maintains its cautious approach towards reprogrammed depositors and continue its efforts to build-up the liquidity needed to meet the next tranche of deposits falling due beginning in August 2005. 
In addition to the liquidity concerns, the reprogrammed deposits carried an interest rate of 6 percent, well above market rates and resulting in a significant drag on earnings. Considering the repayments and the favorable developments in the financial sector, the authorities have reduced the interest rate on reprogrammed deposits to 3.5 percent, thus helping BROU's net operational earnings. BROU also suffers from high operating costs that are due to excessive personnel and branches, aspect that is also being addressed in the restructuring program. 
Press Release No. 04/32

FOR IMMEDIATE RELEASE

February 20, 2004
International Monetary Fund

Washington, D.C. 20431 USA

\section{IMF Completes Fourth Review of Uruguay's Stand-By Arrangement and Grants Waivers}

The Executive Board of the International Monetary Fund (IMF) completed today the fourth review under the SDR 2.13 billion (US\$3.2 billion) Stand-By Arrangement for Uruguay. Completion of the review makes SDR 93.2 million (about US\$141 million) immediately available to Uruguay, and would bring total disbursements under the program to SDR 1.57 billion (about US $\$ 2.4$ billion). As part of the latest review, the Board also approved waivers of nonobservance and applicability of a few performance criteria, and a request that certain repayments arising during 2004-in an amount equivalent to SDR 227 million (about US\$343 million) - be moved from an expectation to an obligations basis at later dates.

Further disbursements in four equal installments of SDR 139.8 million each (about US\$211 million) are expected to be made following the completion of Executive Board reviews tentatively scheduled for May, August, and November 2004, and February 2005.

The current Stand-By Arrangement was initially approved on March 25, 2002 in an amount of SDR 594.1 million (about US\$823 million) for a 24-month period (see Press Release No. 02/14). The arrangement was augmented by SDR 1.16 billion (about US $\$ 1.6$ billion) on June 25,2002 (see News Brief No. 02 154), and by SDR 376 million (about US\$521 million) on August 8, 2002 (see News Brief. No. 02/87).

In commenting on the Executive Board decision, Agustín Carstens, Deputy Managing Director and Acting Chairman, said:

“Uruguay's performance under the Stand-By Arrangement continues to be favorable. The economic recovery is well under way, financial market conditions are improving, and economic indicators are pointing up this year. Prudent macroeconomic policies, skillful resolution of the 2002 banking crisis, and the successful debt exchange in early-2003 have been key to the economy's turnaround.

"Consolidating the recovery will require continued sound macroeconomic policy implementation, and redoubled efforts at structural reform, particularly in the fiscal and banking areas. The authorities' strong commitment to achieving the program targets for the primary fiscal surplus and sound management of monetary policy under the floating exchange rate, along with progress in banking sector reform, are key. 
"The authorities are committed to attaining the fiscal primary surplus target in 2004, underpinned by the projected cyclical recovery of revenue, improvements in tax administration, continued expenditure restraint, and utility tariffs aligned with costs. Priority social expenditures will remain protected under the program. Progress on tax reform is essential to supporting a sustainable fiscal improvement, and along with reform of the specialized pension funds will help unlock multilateral financing and reduce reliance on short-term debt.

"Monetary policy will continue to target base money, under the floating exchange rate regime. Over the medium term, the authorities intend to move toward inflation targeting, and as part of the preparations for this, they have initiated a regular survey of inflation expectations.

"Restructuring of the public banks and swift disposal of the remaining assets of the liquidated banks arc crucial for banking system stability and the revival of credit flows. The authorities have taken important steps to remove nonperforming loans from the balance sheet of the public bank, BROU, and to initiate its operational restructuring, and intend to carry forward with further reforms in the coming months to ensure the bank's viability. Progress is also being made in restructuring the state mortgage company, $\mathrm{BHU}$, outsourcing the asset disposal of three liquidated banks, and strengthening banking regulations to align them with international best practices.

"The authorities need to build a consensus for reforms to enlarge the role of the private sector and increase competition. This will serve as a basis for supporting growth and economic diversification, and deepening Uruguay's global economic integration and reducing its vulnerability to regional developments.

"The authorities have set themselves an ambitious policy and reform agenda that will be a challenge to implement, especially during this election year. Nevertheless, there is no room for complacency, as the recovery is still fragile and continued strong program implementation will be necessary to boost growth in a lasting way, bolster market confidence, and ensure sustainable debt dynamics," Mr. Carstens said. 